Historic, Archive Document

Do not assume content reflects current scientific knowledge, policies, or practices. 



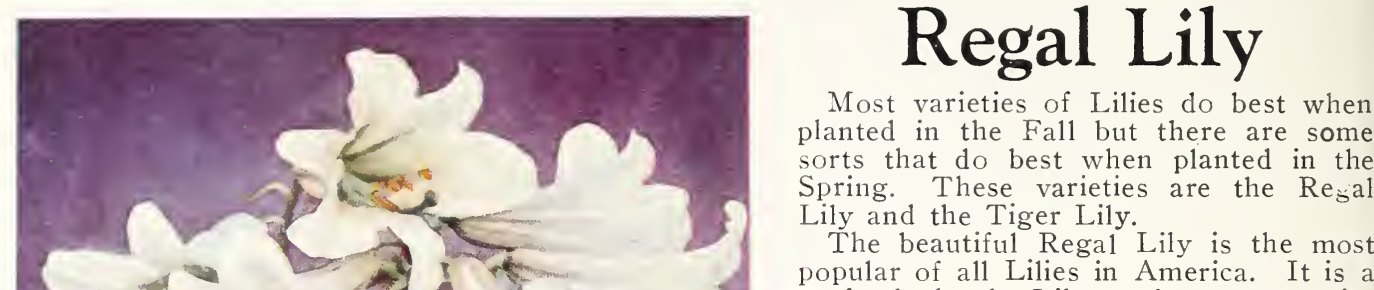
planted in the Fall but there are some sorts that do best when planted in the Spring. These varieties are the $\mathrm{Re}_{\Varangle} \mathrm{al}$ Lily and the Tiger Lily.

The beautiful Regal Lily is the most popular of all Lilies in America. It is a perfectly hardy Lily, makes a very vigorous growth, thrives best in a rich, leafy loam, but will grow in any good average soil that is well drained. It has long, slender, strong flower stems which grow from 3 to 5 feet tall and are covered with dense, narrow foliage. A very profuse bloomer of long funnel-shaped blooms. General color effect white, shading gradually on the inside to a golden throat. On the outside shading back from a pure white through pink to brown. Fragrance very pleasant. Blooms in July. Plant bulbs 8 to 10 inches deep.

Each Per 3 Per 12 Strong Medium Size. $\quad .40 \quad 1.00 \quad 3.50$ Special: Nice, small blooming size, $25 \mathrm{c}$ each; 5 for $\$ 1.00 ; 25$ for $\$ 4.00 ; 100$ for $\$ 15.00$.

\section{Butterfly Bush}

\section{(Buddleia or Summer Lilac)}

This shrub, which is of comparatively recent introduction, grew into public favor almost at once.

It is a semi-herbaceous plant, by which is meant that in some latitudes, where the weather is severe in the Winter, it dies almost to the ground, and the tops, where it does this, must be cut to within four inches of the ground in the Spring, when it always throws up a new growth and by Summer is in full bloom. We advise the covering of the roots as Winter approaches with leaves or coarse litter, which will cause the bush to be much prettier the next season. It is very hardy, blooms the first season, from midJune until frost. The blossoms are borne on long, graceful stems which terminate in tapering panicles of lilac colored flowers which look very much like the bloom of the lilac. The flower head is often 10 inches long and the bloom so profuse that the entire plant is hidden by flowers.

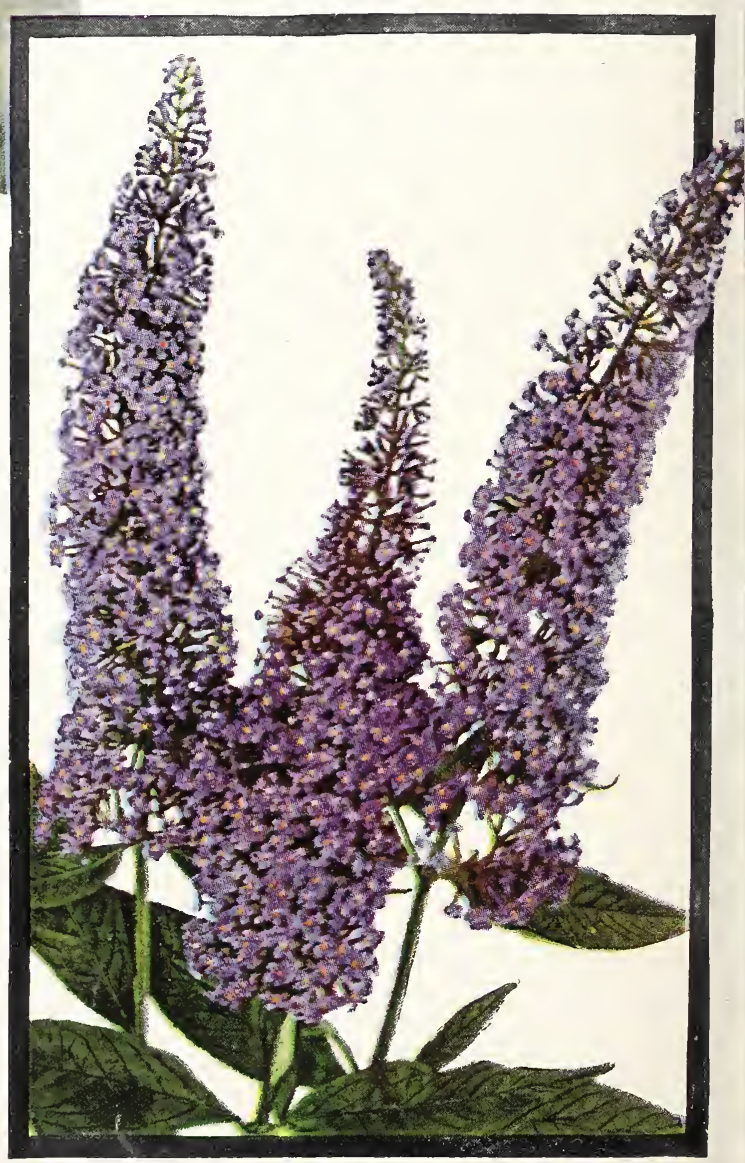




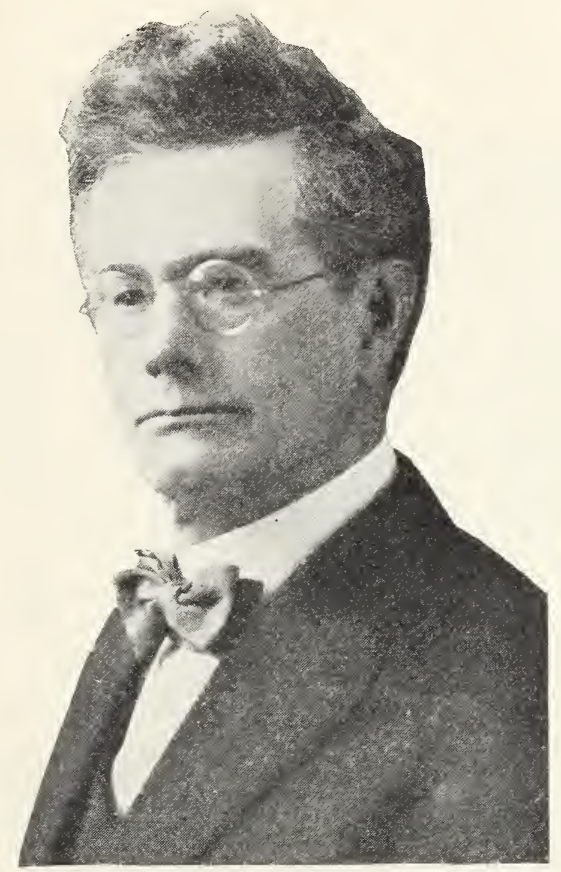

A. M. Brand, President

Brand Peony Farms, Inc.

$\mathrm{O}$

UR nursery was founded at Faribault, Minnesota, by Oliver F. Brand in 1867, and is the oldest nursery in the State of Minnesota. It was first operated under the name Faribault Nursery, and as such continued until the year 1899. That fall, A. M. Brand, one of the present owners, entered the business with his father; and until 1911 the firm name was O. F. Brand and Son. In the fall of that year, O. F. Brand retired from the business because of failing health, and moved to California, where he passed away in 1921.

With the retirement of the elder Mr. Brand, a new firm was organized. It operated as the Brand Nursery Company until 1925. Then, in view of the fact that the single item of peonies was fast becoming our main line, the firm name was again changed. It became the Brand Peony Farms, and in the beginning of 1929 was incorporated under the firm name Brand Peony Farms, Incorporated, with A. M. Brand, President, and Myrtle G. Gentry, Secretary-Treasurer.

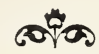




\section{Instructions For Ordering}

ORDER BLANK Be sure to use the order blank and return envelope enclosed. This prevents errors and enables us to give the order more prompt attention. But should you lose the order blank then use your letter paper.

ORDER EARLY By ordering early you will be sure to get everything that you order as our stock will be unbroken, and you will get the stock early and it will give you much better results. March and April are the months that give best planting results.

TERMS Cash should accompany all orders unless credit has been provided for in advance. A 5\% cash discount may be deducted from or a $10 \%$ stock discount may be added to all orders amounting to $\$ 5.00$ accompanied by cash where the order is mailed to us by March 31, 1930. That is if your order amounts to $\$ 5.00$ you may either take a $5 \%$ cash discount and send check for $\$ 4.75$ or you may send check for $\$ 5.00$ and order nursery stock to the amount of $\$ 5.50$.

REMITTANCE Should be made by Bank Draft, Post Office Money Order, Express Money Order, by Check, or in stamps and be sure to make it payable to BRAND PEONY FARMS, Inc., and mail it to them care Box 408, Faribault, Minnesota.

Do not send cash or stamps unless you register your letter as they are apt to be lost otherwise.

SUBSTITUTION We never substitute Peonies unless we receive instructions to do so from our customer. But in the spring it is best for peony customers to select a second choice as we might happen to be out of some certain variety ordered and we do not dig peonies in the spring. If not absolutely particular kindly give us permission to substitute if necessary and if we have to you will not lose by our so doing.

As to other nursery stock we reserve the right to substitute if out of an article ordered. But if we do substitute we will use an article similiar and of equal or greater value. But if you wish no substitution simply state in your letter or order Do Not Substitute and in that case we will refund money for anything we cannot supply. If we do substitute we will always label true to name.

$\$ 1.00$ We will fill no order for less than $\$ 1.00$.

PARCEL POST Please do not ask to have trees or bushes taller than 3 to 4 feet sent by parcel post. The Parcel Post laws will not permit it. We cannot send 5 to 6 foot trees by Parcel Post, they are too large.

\section{BRAND PEONY FARMS, INC. Faribault :: :: Minnesota}




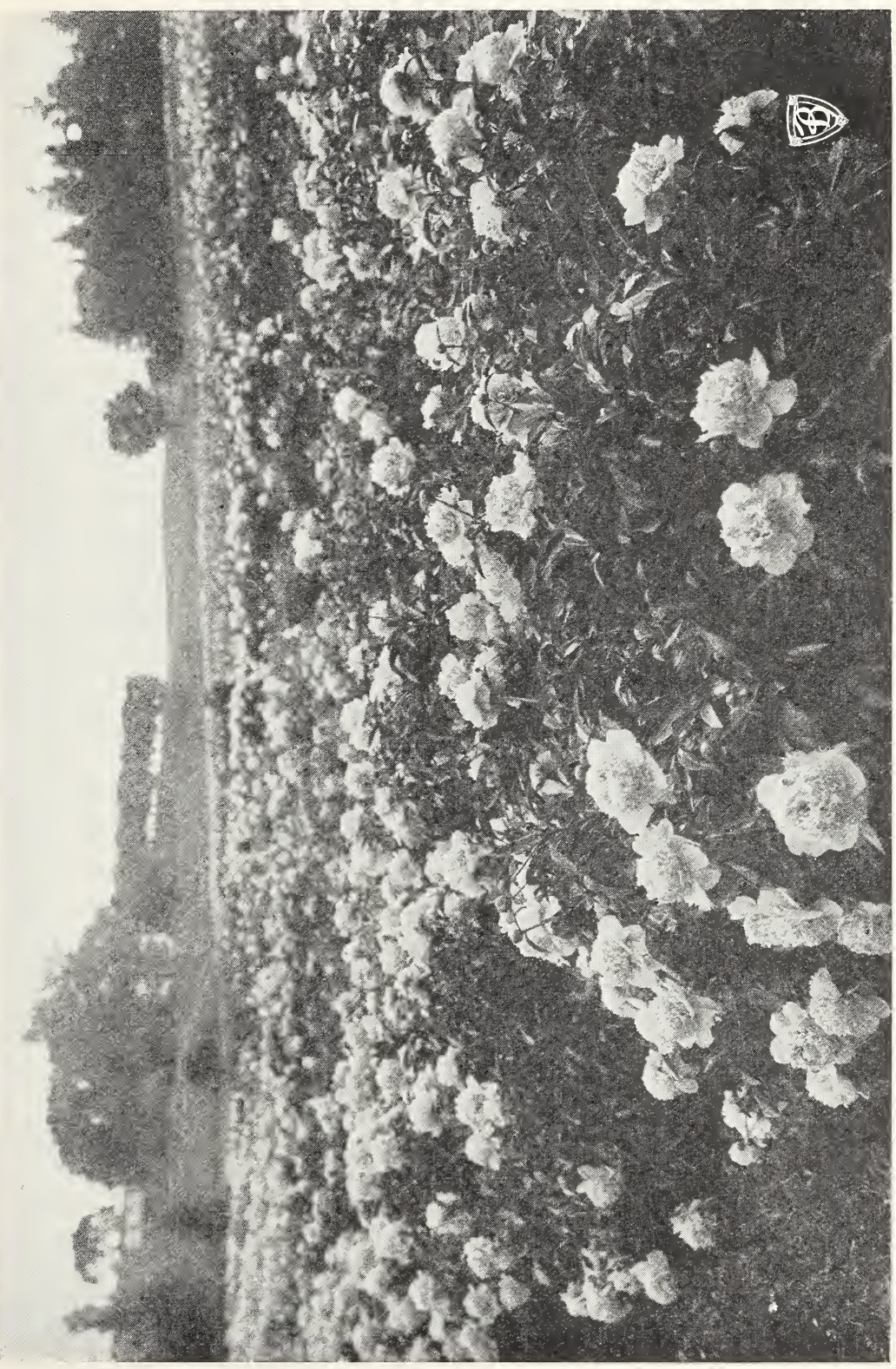

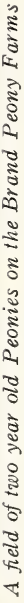




\section{Peonies for Spring}

\section{Our Prices Hold Good For Spring of 1930 Only}

W E DO an immense business in peonies every fall, and we also receive a lot of fine letters from our customers in return. But this last season it seems that we received an unusual number of complimentary letters from our customers which would wind up in some such manner as this: "The roots I received from you were simply marvelous " "The nicest roots I ever saw " "I have bought peonies for years and from many places but never anything so wonderful as these."

Now we did send out some fine peonies last fall. We intended to, and we are going to send some more out this spring just like them. Yes, a lot of them, because we have the stalls down in our peony room in the big storage building just filled with great big nice roots. These roots will give just as good results to our customers as those sent out in the fall and we expect just as many nice letters in return.

\section{Can Peonies Be Planted in the Spring Successfully? Yes.}

We have been growing and selling peonies in a large way right here at Faribault for 60 years. We have always handled lots of peonies in the fall and we have always handled lots of peonies in the spring. Through all these years we have never seen any difference in the final results between fall and spring planting.

\section{Instructions for Planting of Peonies}

In planting a peony, first dig a large hole about the size and depth of a bushel basket. Put back into the hole good mellow top soil and keep tramping it down solid with the foot until the hole is filled up so that when you place the root standing straight up in the center of the hole, the top of the average of the red buds is about two inches below the ground level. Then fill in the soil and work it in carefully about the roots, pressing it down hard with the foot until the hole is level full. Throw a light mulch of coarse litter over the plants the first winter.

The peony should be planted in full sun if possible. Do not plant in a wet sour soil or where water stands for any length of time. If the plants are set in the lawn remove the sod for a circumference of two feet and bring in loose mellow dirt to take the place of the sod. Always keep the soil mellow about the peonies. Peonies do not do well in soil under large trees.

We give full instructions as to the care of peonies in our Peony Manual. This is a large 64 page book which tells all about the varieties, the history, and the care of the peony. It is chock full of information, well written, printed on fine paper, profusely illustrated. A copy of this book is sent free with all orders amounting to $\$ 5.00$ or over, or we otherwise charge $\$ 1.00$ for it.

8.8-Addielanchea (Brand). One of the purest and most beautiful of all the whites. This is a new peony and there is little stock of it. Very choice. $\$ \mathbf{5 . 0 0}$.

8.5-Adolphe Rosseau .(Dessert \& Mechin). Rich dark red. Tall, semi-double, early. \$1.00.

7.6-Alba Sulfurea (Calot). Creamy yellow. Midseason, profuse bloomer. $\$ \mathbf{1 . 0 0}$.

8.6-Albert Crousse (Crousse). Beautiful soft shell pink. Late. \$1.00.

7.5-Archie Brand (Brand). Deep shell pink with silvery border. Immense flower. \$1.00.

8.7-Auguste Dessert (Dessert). Velvety crimson carmine. A new French variety of unusual merit. \$4.00.

8.0-Aviateur Reymond (Dessert). Beautiful bright cherry red with deeper shadings. $\$ \mathbf{2 . 0 0}$.

9.0-Baroness Schroeder (Kelway). A beautiful tinted white fading to pure white. Late. $\$ \mathbf{1 . 5 0}$.

8.1-Benjamin Franklin (Brand). Very tall, early, brilliant red. Profuse bloomer. $\$ 1.00$.

New-Blanche King (A. M. Brand). A most promising deep bright pink. \$50.00 net.

8.4-Candeur (Dessert). A delicate silvery pink, tinged lilacrose. An unusually fine show flower. \$2.00.

7.8-Charles McKellip (Brand). A brilliant deep red. Splendid cut flower. $\$ \mathbf{1 . 0 0}$

8.6 Cherry Hill (Thurlow). Very early, brilliant cherry red. Tall. $\$ 2.50$.

8.4-Chestine Gowdy (Brand). Pink and cream. Very late. Excellent cut flower. $\$ \mathbf{1 . 0 0}$.

8.5- Clemenceau (Dessert). Late carmine rose with silvery border. This was one of our most striking show flowers last season. $\$ 3.00$.
8.1-Couronne d'Or (Calot). A good late white with a circle of golden stamens. $\$ \mathbf{1 . 0 0}$.

8.5-Desire (Brand). A delicate mauve pink with yellow stamens. Beautiful. $\$ \mathbf{2 . 5 0}$

8.1-Duchess de Nemours (Calot). A pure creamy white showing green carpels. $\$ \mathbf{1 . 0 0}$.

9.2-E. B. Browning (Brand). Immense white tinted delicate shell pink. Orange tracings at base. \$2.50.

7.6-Edulis Superba (Lemon). Finest early deep pink. Northern decoration day flower. $\$ \mathbf{1 . 0 0}$.

8.5-Elisa (Dessert). New French variety. Soft shade of bright pink tinted salmon. Very choice. $\$ \mathbf{5 . 0 0}$.

New-Ella Christianson (A. M. Brand). Deep pink. Strong grower, free bloomer. Mid-season. $\$ 50.00$ net.

8.7-Elwood Pleas (Pleas). Late light shell pink. Very fragrant. \$1.00.

8.9-Enchanteresse (Lemoine). A pure creamy white splashed with crimson. Late. Extra good for extreme north. $\$ 2.00$.

8.3-Eugene Bigot (Dessert). A very fine brilliant dark red. Best late red cut flower variety. $\$ \mathbf{1 . 0 0}$.

8.3-Eugene Verdier (Calot). Flesh pink with distinct yellow shadings showing in the collar. Late mid-season. \$1.00.

8.6-Eugenie Verdier (Calot). Light hydrangea-pink. An excellent flower. Midseason. \$1.00.

8.2-Faribault (Brand). Deep rose with a silver sheen. Splendid late cut flower. $\$ \mathbf{1 . 0 0}$.

8.4-Felix Crousse (Crousse). A deep rose red. A pure globular type with no stamens. $\$ \mathbf{1 . 0 0}$. 
9.3-Festiva Maxima (Miellez). Purest white with flecks of intense crimson. Large and early. \$1.00.

9.1-Frances Willard (Brand). Blush white with an occasional carmine touch. Midseason. \$1.50.

8.1-Galathee (Lemoine). Flesh white. Pronounced pleasant fragrance. Tall, strong grower. Late. \$1.50.

General Gorcas (Vanleeuwen). New. Cup shaped flowers. Large petals, white with some petals flecked crimson. Stock scarce. \$6.00.

8.8-Grandiflora (Richardson). Soft shell pink. Flowers very large. Unusually late. $\$ \mathbf{\$ 1 . 0 0}$

8.1-Grandiflora N. Plena (Lemon). Very early white, showing markings of crimson. Sulphur yellow at base of petals. True stock scarce. $\$ 1.00$.

New-Hansina Brand (A. M. Brand). Immense flower Opens flesh pink. Fades to Solange color. Late, strong grower. \$50.00 net.

New-Hazel Kinney (A. M. Brand). Beautiful large hydrangea-pink. Midseason. Great show flower. \$50.00 net.

9.2- Jeannot (Dessert). A delicate lavender pink with salmon pink shadings at base of petals. Wonderful flower. $\$ \mathbf{5 . 0 0}$

8.9-Jubilee (Pleas). Immense pure white with long narrow lacy petals. $\$ 1.00$

7.7-H. F. Reddick (Brand). Splendid late dark red. A profuse bloomer and a good cut flower. \$1.00.

8.7-James Kelway (Kelway). Opens a flesh pink which soon changes to a beautiful white. Midseason. $\$ \mathbf{\$ 1 . 0 0}$.

8.8-Karl Rosenfield (Rosefield). Early midseason. Rich bright red. A splendid all around flower. \$1.00.

9.0-Katherine Havemeyer (Thurlow). One of Thurlow's finest pinks. Late and fragrant. $\$ 5.00$.

8.8-Kelway's Queen (Kelway). A uniform mauve pink with center flecked crimson. A distinct peony. Ours is the true variety. $\$ \mathbf{5 . 0 0}$.

9.1-Lady Alexandra Duff (Kelway). This is a flesh pink that one must see to appreciate its wonderful beauty. $\$ \mathbf{\$ 1 . 0 0}$. Kelway's Exquisite (Kelway)

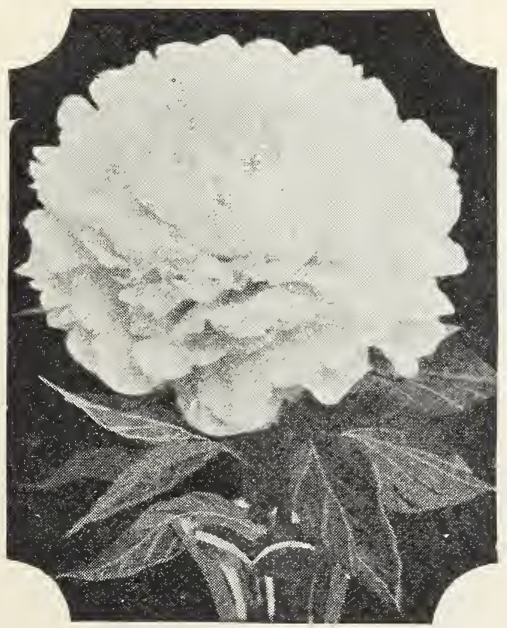

Myrtle Gentry

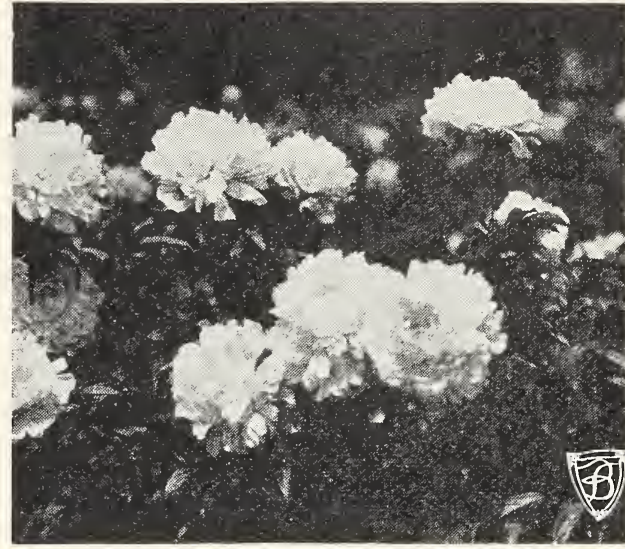

Ella Christianson

7.8-Lafayette (Dessert). A lovely shade of salmon pink. A really good peony. $\$ 1.00$.

9.2-La Fee (Lemoine). A beautiful mottling of different shades of pink. A striking show flower. Our stock is true and clean. $\$ 4.00$.

New-Lake O'Silver (Franklin). A pink silver tipped variety with golden anthers showing throughout. \$1.50.

8.6-La Lorraine (Lemoine). Soft even shade of creamy pink. Midseason. A wonderful show flower. \$4.00.

8.3-La Rosiere (Crousse). A beautiful loosely built white with a band of yellow stamens around the center. \$1.00.

9.9-Le Cygne (Lemoine). An almost perfect creamy white. The highest rated peony. $\$ \mathbf{5 . 0 0}$.

8.1-Livingstone (Crousse). A late deep pink of perfect rose type. $\$ 1.00$.

9.0-Longfellow (Brand). A striking bright crimson which does not fade in the sun. One of the highest rated reds. $\$ 2.50$.

8.4-Lora Dexheimer (Brand). An intense flaming crimson. Early midseason. Beautiful in form. \$1.00.

7.6-Lord Kitchener (Renault). A very early bright red Valuable because it is early. Shows no stamens. \$1.00.

8.8-Loveliness (Hollis). Hydrangea Pink, changing to lilac white. Hollis' best peony. Splendid show flower. Very late. $\$ 1.00$

8.6-Mme. Auguste Dessert (Dessert). Uniform violet-rose petals slightly flecked crimson. Early midseason. \$1.50.

7.9-Mme. De Verneville (Crousse). Large bomb type. Guards white with center showing carmine tracing. Great cut flower. Rated much too low. \$1.00.

8.5-Mme. Emile Galle (Crousse). Delicate sea shell pink. Extra fine in bud. One of the best late varieties. Resembles Tourangelle. \$1.00.

8.9-Mme. Emile Lemoine (Lemoine). A tall strong growing white. One of the very best peonies. Late midseason. $\$ 1.00$.

9.4-Mme. Jules Dessert (Dessert). A creamy white, lighted with buff and salmon shades. A few golden stamens add beauty to an already beautiful flower. $\$ \mathbf{1 . 5 0}$.

8.5-Mme. Manchet (Dessert). A late lilac pink. Colo striking and a profuse bloomer. $\$ 1.00$. 


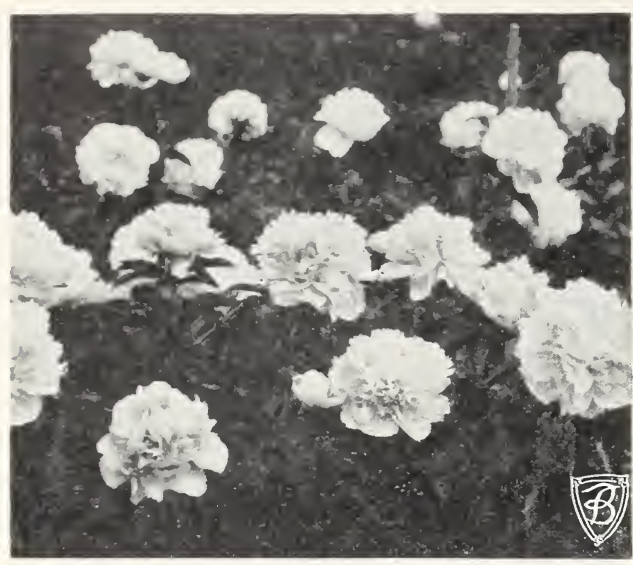

Some of our new seedlings not yet introduced

8.3-Marie Jacquin (Verdier). White guard petals surround a collar of yellow stamens. Semi-double. \$1.50.

8.4-Marguerite Gerard (Crousse). Delicate hydrangea pink changing to a creamy white. Splendid garden flower. $\$ \mathbf{\$ 1 . 0 0}$

9.1-Martha Eulloch (Brand). Mammoth late pink. A good garden flower as well as a show flower. $\$ 4.00$.

8.7-Mary Brand (Brand). An outstanding deep crimson. Midseason. A real show flower. $\$ 2.00$.

9.0-Milton Hill (Richardson). Delicate salmon pink. Large flower. Late. \$2.50.

8.3-Monsieur Dupont (Calot). Late midseason white. Center splashed crimson. Profuse bloomer. Strong grower. $\$ 1.00$.

9.3-Mons. Jules Elie (Crousse). Very early fragrant rose pink. Enormous blooms. \$1.00.

8.8-Mons. Martin Cahuzac (Dessert), Darkest maroon red peony. Medium early. \$2.00.

8.4-Mont. Blanc (Lemoine). Milk white with center slightly tinted rose. Midseason. $\$ \mathbf{1 . 5 0}$.

9.6-Mrs. A. M. Brand (A. M. Brand). The Gold Medal White. A wonderful new peony. Late. $\$ 50.00$ net.

New-Mrs. F. A. Goodrich (A. M. Brand). Deep uniform pink. Large, late, and fragrant. Award of merit at London, Ontario. $\$ 50.00$ net.

New-Mrs. Frank Beach (A. M. Brand). Large flat ivory white. Long narrow lacy petals. A glorified Jubilee. $\$ \mathbf{5 0 . 0 0}$ net.

New-Mrs. Harriet Gentry (A. M. Brand). A pure rose type glistening white. Stock scarce. Late. \$50.00 net.

New-Mrs. John M. Kleitsch (A. M. Brand). A violet rose with a distinct lavender cast. A wonderful late, fragrant variety. \$50.00 net.

New-Myrtle Gentry (A. M. Brand). A late Tourangelle pink of large size and splendid iorm. A true rose fragrance. Silver medal. \$50.00 net.

9.0-Nina Secor (Secor). Beautiful white of exquisite form with tiny lacy petals. $\$ 5.00$.

8.8-Nymphaea (Thurlow). A splendid white with petals so arranged as to strikingly resemble a water lily. \$1.50.

8.8-Phoebe Cary (Brand). A second Martha Bulloch. A beautiful lavender pink in bloom with Marie Lemoine. Very tall. A great peony. $\$ 3.00$.

8.8-Phyllis Kelway (Kelway). A bright pink flower of great size with long narrow petals loosely arranged. $\$ \mathbf{5 . 0 0}$.
8.2-Pierre Duchartre (Crousse). A late clear pink that bears a striking resemblance to La France. An excellent variety. $\$ 1.00$.

New-President Coolidge (A. M. Brand). A late large pink of good color and wonderful form. One of the finest of all for landscape effect. $\$ \mathbf{5 0 . 0 0}$ net.

8.6-Primevere (Lemoine). One of the best true yellow peonies. Very choice. \$2.00.

9.0-Raoul Dessert (Dessert). Mauve with carmine pink shadings and silvery reflex. Extra choice. \$3.50.

8.7-Reine Hortense (Calot). Uniform hydrangea pink. flecked with crimson. A truly wonderful flower. \$1.00.

8.8-Richard Carvel (Brand). The best of all early reds. Very fragrant. Wonderful early cut flower. $\$ \mathbf{2 . 5 0}$.

9.0-Rosa Bonheur (Dessert). Light violet rose, with guard petals flecked crimson. One of the best show flowers. \$1.50.

8.8-Rosette (Dessert). A pretty fine shaped flower. Silvery pink with a touch of crimson on the edge of the petals. \$2.50.

7.9-Ruth Brand (Brand). A soft lavender pink. Early splendid cut flower. Does exceedingly well in the south. \$1.00.

9.0-Sarah Bernhardt (Lemoine). A large apple blossom pink. Very showy flower both in field and show room. \$1.50.

9.7-Solange (Lemoine). Deep orange salmon overlaid with a delicate rich cream. Late. \$2.50.

9.1-Souvenir De Louis Bigot (Dessert). Salmon pink. Resembles Walter Faxon. Better field flower. Very choice. \$2.50.

9.8-Therese (Dessert). Analmost perfect pink peony. $\$ 2.00$

9.4-Tourangelle (Dessert). A late delicate lavender pink. When in perfect form we think this the most beautiful of all peonies. $\$ 2.00$.

9.3-Walter Faxon (Richardson). A clear self color salmon pink. One of the greatest show flowers. \$2.50.

8.8-W. F. Christman (Franklin). Delicate flesh pink. Rose type and fragrant. Midseason. \$2.00.

8.3-Winnifred Domme (Brand). A brilliant scarlet red. No other like it. Brightest of all reds. Early midseason. \$1.50.

7.9-Wm. Penn (Brand). Light rose. Flowers very large. One of the most fragrant of all peonies. \$1.00.

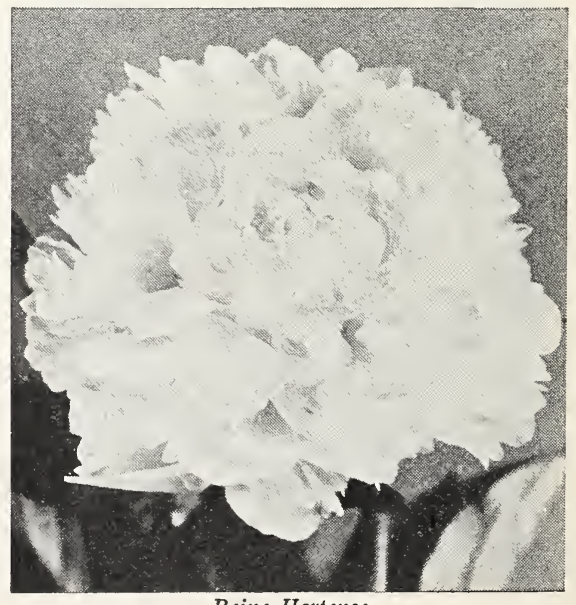

Reine Hortense 


\section{Single Peonies}

WE HAVE in storage a number of single peonies, but our supply of any one variety is limited.

We have decided to offer three good singles, our selection, for $\$ \mathbf{5 . 0 0}$. These roots will all be correctly labeled and chosen from the following varieties: Albiflora, Avant Garde, Harriet Olney, Laciniata, La Printemps, Darkness, Marguerite Dessert, Mellen Knight, Pride of Langport, and Watteau.

The value of any collection that we send out will equal more than twice what you pay for it.

\section{A Few Singles of Which We Have a Quantity in Storage}

Flanders Fields (A. M. Brand). A single of the most brilliant red. Two rows of petals surround a large prominent center of golden stamens. The petals stand out flat and are of great substance, rich and velvety in appearance. \$5.00.

Krinkled White (A. M. Brand). The bud of this variety resembles a pale pink tulip. As it opens it develops into a large flower with great broad pure white petals that are krinkled like crepe paper. A splendid show flower and a splendid field flower. $\$ 5.00$.

Laciniata. Bright scarlet red. Foliage distinctly different from that of the Chinensis peony being finely cut although not so fine as that of Tenuifolia. This peony blooms even earlier than the Officionalis peonies. $\$ \mathbf{\$ 3 . 5 0}$.

\section{Japanese Peonies}

We have a few nice Japanese varieties in storage. We will send three fine Japanese peonies none worth less than $\$ 3.00$ per root, all different, all labeled, for \$5.00. In these collections you will find such varieties as Akashigata, Alma, Altar Candles, and King of England.

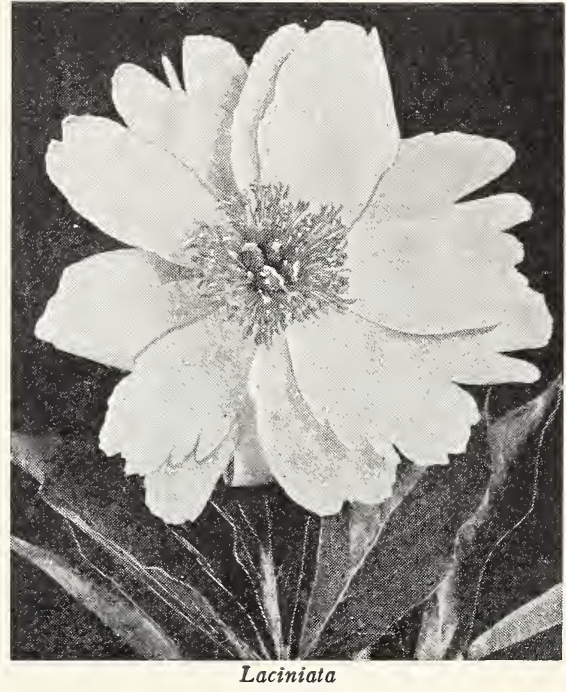

Peony Collection " $A$ "

Ten of the World's Best Peonies for $\$ 25.00$

Could you make a choicer or better balanced collection than you find in the following list?

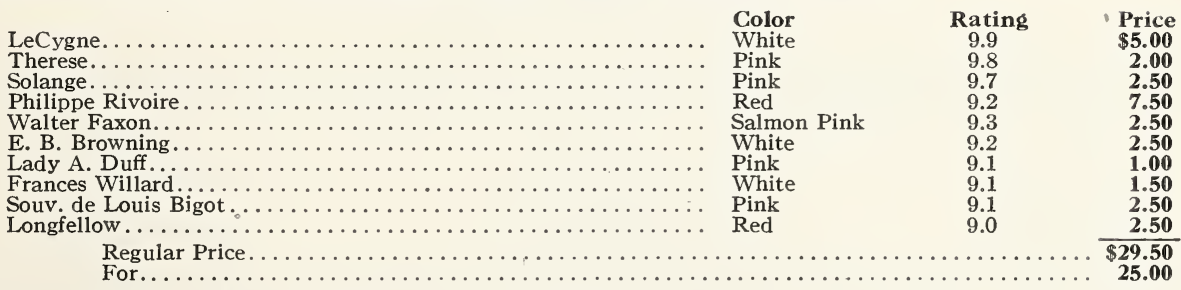

Every one of the ten varieties is included in the world's twenty-six best peonies.

Every one rates 9 or above.

The list includes reds, whites, light pinks, and dark pinks. Some are early, some are mid-season, and others are late bloomers. Every root in any of our collections carries from three to five or more eyes.

This list of peonies if purchased separately amounts to $\$ 29.50$. We are offering the entire list for spring only for $\$ 25.00$.

\section{Peony Collection " $B$ " Three Early Blooming Varieties} list:

If you wish three early peonies, a red, a white, and a pink, that come into bloom at the same time, we recommend the following

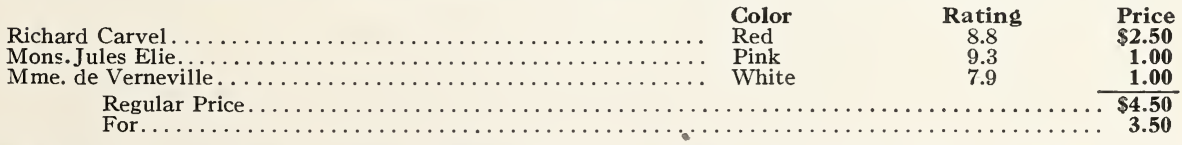

These three peonies are among the earliest varieties to bloom, and they make a beautiful group. They are all of the same type and all have a pleasing fragrance.

We have lowered our prices this spring and we are offering the above three varieties for $\$ 3.50$. 


\section{Peony Collection " $C$ "}

Three Late Mid-Season Blooming Varieties for $\$ 4.50$

In our previous catalog we offered three excellent varieties that will come into bloom after those in the preceding collection These were:

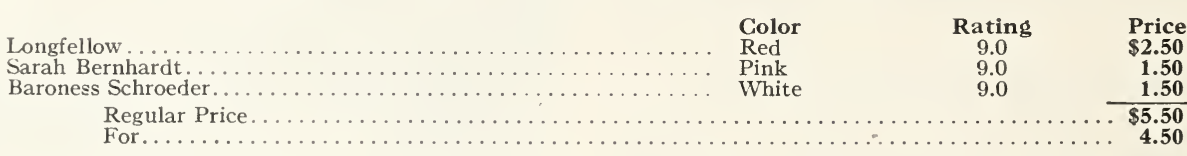

\section{Peony Collection " $D$ ”}

\section{List of Very Late Varieties for $\$ 9.00$}

If you wish to extend the blooming season by adding three very late varieties, we call your attention to the following group:

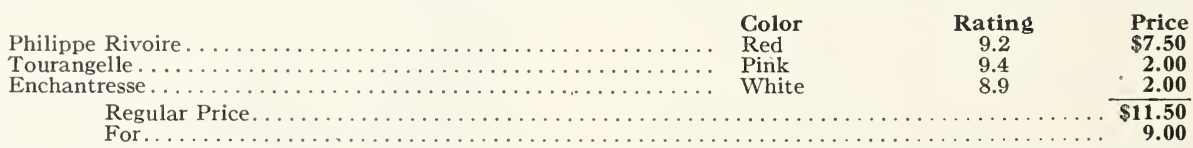

Philippe Rivoire is the highest rated red on the market. This variety has no stamens and for this reason is particularly desirable. Both Tourangelle and Enchantresse are real show flowers. At the National Peony Show held in Peoria, Illinois, where Tourangelle was exhibited in true show form it won the prize as the best flower in the show room.

\section{Peony Collection “ $E$ ”' $\$ 12.00$}

\section{For Beginners}

For your first peonies, we believe we have selected from the standard varieties twelve of as good peonies as you can purchase for the money. Three in the list rate 9.0 or above and belong in the world's twenty-six best. No peony in the list rates below 8.0 . Entire list of twelve good peonies for $\$ \mathbf{1 2 . 0 0}$.

\section{RED}

8.1 Ben Franklin

8.4 Lora Dexheimer

8.8 Karl Rosefield

8.7 Mary Brand

\section{PINK}

8.6 Eugenie Verdiier

8.8 Grandiflora

8.1 Livingstone

9.3 Mons. Jules Elie

\section{WHITE}

9.1 Frances Willard

9.3 Festiva Maxima

8.k Couronne d'Or

8.3 Mons. Dupont

One of our customers in Memphis, Tennessee, wrote as follows on May 19, 1928: "Three years ago I ordered Festiva Maxima, Mone. Jules Elie, and Ben Franklin. The first spring they all had from one to three blooms on each plant the second spring they had from two to four blooms but this spring I never saw such a wonderful display. It looked as if each one was trying to outdo the other. The Festiva Maxima and Mons. Jules Elie were wonderful, but my favorite was Ben Franklin. It was such a deep, dark, glorious red."

All three of these varieties are found in the above collection with nine others equally desirable.

\section{Peony Clearance Collection}

By the 10th of May we hope to have every stall in our large peony packing room empty. To accomplish our aim, we are going to offer a collection of ten good peonies at a cheap price. Remember, it is the price that is cheap and not the peonies. The roots will all be large, three to five or more eye divisions.

Every root will be labeled absolutely true to name.

No two roots will be alike.

You will receive red, white, and pink varieties. These varieties have all been listed in our previous catalogs. Remember, we are making this offer to clear our room.

WE WILL SEND TEN GOOD PEONIES, ALL COLORS, ALL LABELED, FOR \$5.00. 


\section{Brand's Peony Manual}

By A. M. Brand

Mr. Brand has grown peonies on a more or less large scale for over 50 years, and is thoroughly familiar with his subject.

He has given us a book that is not only well written, but it is well printed, on fine paper, and profusely illustrated. It treats the peony from many different viewpoints and goes thoroughly into its history, varieties, and culture.

This book is sent free to all our customers who send us an order for $\$ 5.00$ or more of stock from either this catalog or from our catalog this fall provided they do not already have a copy of the book and also providing they ask for the Manual in their order, or we will send the book to anyone for the price of $\$ 1.00$.
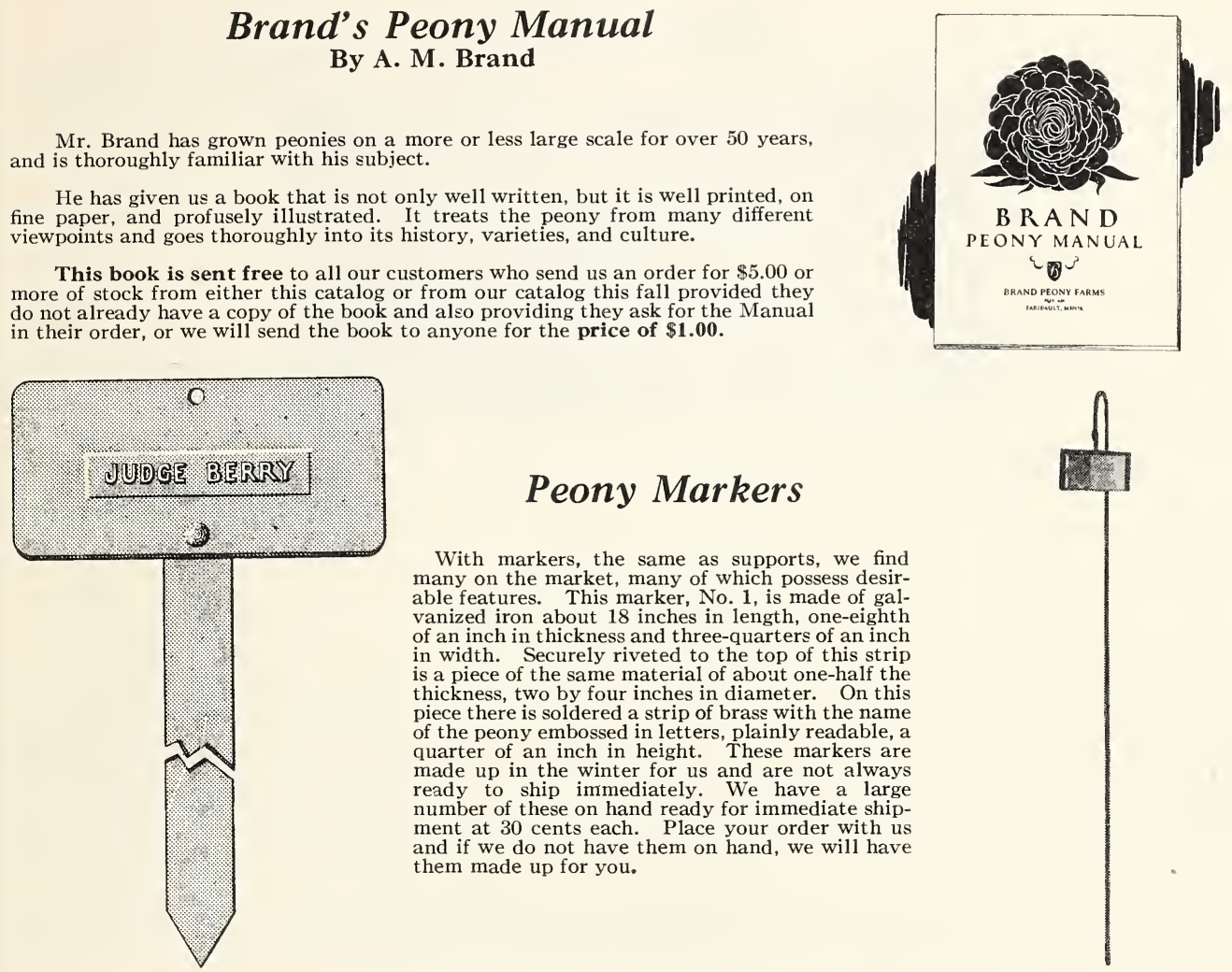

\section{Peony Markers}

With markers, the same as supports, we find many on the market, many of which possess desirable features. This marker, No. 1, is made of galvanized iron about 18 inches in length, one-eighth of an inch in thickness and three-quarters of an inch in width. Securely riveted to the top of this strip is a piece of the same material of about one-half the thickness, two by four inches in diameter. On this piece there is soldered a strip of brass with the name of the peony embossed in letters, plainly readable, a quarter of an inch in height. These markers are made up in the winter for us and are not always ready to ship immediately. We have a large number of these on hand ready for immediate shipment at 30 cents each. Place your order with us and if we do not have them on hand, we will have them made up for you.

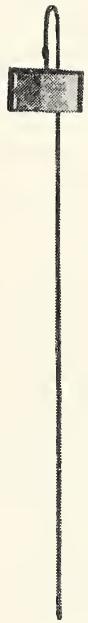

\section{Bloom-Ade Marker}

This marker is made of galvanized steel, painted dark green like the Bloom-Ade support. It stands three feet out of the ground. By referring to the cut you will see that this marker consists of two parts, the standard and the marker container. The marker container is $2 \frac{1}{2}$ by 5 inches. This is made of metal having a transparent weather proof front which protects the name and record of the plant from the elements. This is a very neat, attractive, and serviceable marker. Ready to ship at all times at 25 cents each. The Bloom-Ade Peony Support carries the same marker without the standard.

\section{Peony Supports}

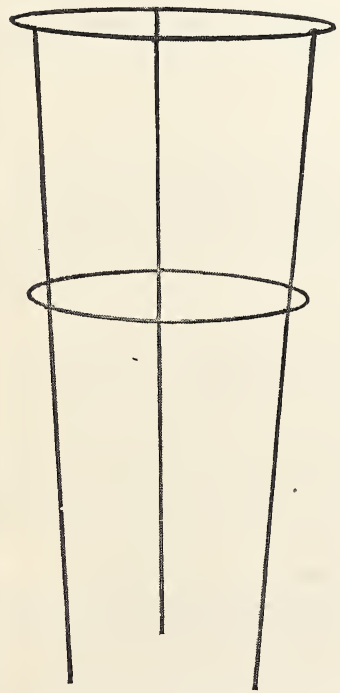

Every peony grower has felt the need of protecting his plants from damage by wind and rain and thus preserving their beauty throughout the entire blooming season. We are handling two different peony supports which will hold the plant erect and keep the flowers off the ground.

\section{The Adams Support}

This support is made of No. 6 galvanized wire that will not rust. They are very substantial and with ordinary care, they should last many years. If they are ordered ahead of time they can be sent by freight, which makes the carriage charges very reasonable.

Special 6 gauge, 24 inch tops, 80 cen ts each.

Shipped by freight or express, F.O.B. Faribault, or factory.

\section{The Bloom-Ade Support With Marker Attached}

This support is made of galvanized steel and nicely painted dark green. It is collapsible and can be put together without tools in a few minutes. It is good looking and very serviceable. This support as you will see carries a splendid water proof marker with it. It is a real ornament to the garden. For peonies we recommen size 16 .

Size 16, with marker attached, $\$ 1.05$ each or $\$ 12.00$ per dozen.

Shipped by freight or express, F.O.B. Faribault or Minneapolis. 


\title{
Improved Lilacs
}

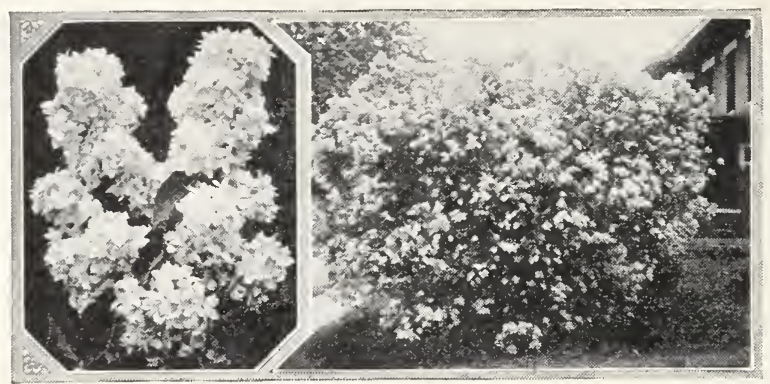

\section{When Lilacs Blow}

$I$ wonder if the tides of spring

Will always bring me back again

Mute rapture at the simple thing

Of lilacs blowing in the rain

If so, my heart will ere be

Above all fear, for I shall know

There is a great mystery

Beyond the time when lilacs blow.

-Unknown.

\begin{abstract}
THE LILAC is one of the hardiest and most beautiful of all our shrubs. Even the old common lilac when in full bloom with
1 the air about it laden with its wonderful perfume, is surpassed by no shrub in the entire list. The common purple lilac is the longest lived of all cultivated shrubs in the northern two thirds of the United States and almost the entire thickly populated portion of Canada. There are immense purple lilac bushes all about Faribault planted by the first wave of white settlers who came into this vicinity back around 1850 that are marvelous shrubs at the present, apparently just as good as they ever were. All over the Eastern portion of this country lilac bushes over a hundred years old are no uncommon sight.
\end{abstract}

The New Lilacs. These new lilacs are all apparently as hardy as the common lilac and will undoubtedly live as long. They come in both singles and doubles, in pure white and creamy white, in purplish red, lilac, and in shades verging on blue and pink. The panicles of some varieties are immense and if one has never seen theselilacs before the first seeing of them is a sensation indeed. they are lovely beyond all power of description.

When to plant. The lilac is one of the very first shrubs to start in the spring and, therefore, it is very important that for best results they should be planted early. If not planted early they seem to stand almost still the first year, throw out but few leaves and look almost dead. Although this seems to do no permanent harm as the second season they start out with vigor and make a fine shrub. Early planting avoids this.

We have all our lilacs in storage and can begin shipments by March 1st. We advise our Southern lilac customers to get their orders in early and we will rush lilac orders to them at the earliest possible date.

Where to Plant. All lilacs love full sunshine, should be planted where there is good root drainage in a rich loamy soil if possible, and if lime is present it is all the better. If the soil is acid add lime and see your lilacs grow.

\section{Own Root French Lilacs}

Own Root Plants. The lilacs we send out are all of our own growing and are all guaranteed to be on their own roots. We have become thoroughly convinced that the own root lilac is the only lilac to plant. It is not practical to grow lilacs grafted on privet or common lilac as such lilacs do not give satisfaction. The production of own root lilacs is a much slower process than these other methods and this makes the price of such lilacs much higher, but we do not consider the lilac as otherwise propagated of any value so the higher priced own root lilacs are much the cheaper in the end.

\section{Lilacs Listed}

We are listing this spring about thirty varieties which cover practically the entire range of colors. Most of these are the older varieties of the improved sorts.

Every lilac in this list is a first class sort and to those who are not familiar with the named kinds we wish to say that you can choose any one variety listed and be sure of getting a good lilac.

\section{Our Entire Lilac List}

We are growing 163 different varieties of Improved Lilacs. As fast as a new lilac comes out we purchase it and begin to multiply it. Eventually we will offer from this great collection all the sorts which we consider desirable. But for this spring we will confine our list to the following desirable kinds. 


\section{White Varieties}

Ellen Wilmot. Double. A large bush with very stout limbs and large thick light green leaves. The flowers come in immense panicles of creamy white, made up of double florets almost twice the size of those of any other double white. In our estimation the greatest double white lilac and one of the three or four finest of all lilacs.

We can supply Ellen Wilmot in small yearling bushes only. The demand for this variety is so great that we never get any large bushes ahead. The plants are small but very nice. 12 to 24 inch own root. $\$ 5.00$ each.

Marie Le Graye. Single. Pure creamy white. When this good single French Lilac first came to us it created a sensation. The panicles are very large and rather openly built. The individual petals and florets are very large. The plant is a young and profuse bloomer, often blooming as a two year old. It produces an immense quantity of bloom which sells very readily at a good price as a cut flower. Own root plants, 2 to 3 feet, $\$ 1.00$. 3 to 4 feet, $\$ 1.50$.

Mme. Lemoine. Double. One of the best of the double whites. Bush grows a foot taller than that of Mme. Casimer Perrier and the bloom is a pure snow white without tinge of cream. Foliage dark green. Panicles large, long, erect; individual florets, large. One of the very good dependable whites. Strong, 2 to 3 feet, own root plants. $\$ 2.00$.

Mme. Casimer Perier. Double. Creamy white. This is a very thrifty growing variety that produces a profusion of large sized panicles of very double creamy white flowers. The bush is medium height, compact, with bright light green foliage. This is a splendid variety, but we have worked up a large stock, so we are making a special price. Everyone should plant one of these beautiful lilacs. Own root plants 2 to 3 feet, $\$ 1.00$. 3 to 4 feet, $\$ 1.50$.

Mont Blanc. Single white. This beautiful lilac is one of the very best of the single whites, if not the best of all. The plant is compact and shapely in growth, with clean foliage. The panicles are large, rather compact, and of beautiful form. The florets are immense in size. Color a clear creamy white. Probably the best single white. Own roots, 2 to 3 feet, $\$ 2.00$.

Mme. Abel Chatney. Beautiful great round globe-shaped buds like Lily-of-the-Valley, which open very slowly into a very large bloom of pure white. A sort very much admired. Own root plants, 2 to 3 feet, $\$ 2.00$.

\section{Blue Varieties}

Alphonse Lavalle. Double. A tall robust growing variety that makes a very shapely bush. Panicles long, broad, shapely, and compact. Opens an intense blue, but as the florets develop it changes into a beautiful shade of lilac. A wonderful bloomer. Splendid sort. Own root plants, 2 to 3 feet, $\$ 2.00$. 3 to 4 feet, \$3.00.

Monument Carnot. This is one of the greatest of all lilacs. The bush grows very tall with great heavy light green leaves. The panicles are of the greatest size from nine inches to a foot long. The florets are large and semi-double. A clear light blue of a most pleasing shade. The finest of all light blue lilacs. Our stock is limited. Own root plants, 2 to 3 feet, $\$ 2.50$. 3 to 4 feet, $\$ 3.50$.

President Grevey. Double. Light blue. In this variety the panicles are very double, symmetrical, of great size and pleasing appearance. The color is a clear soft delicate blue. President Grevey is one of the older sorts and still one of the most desirable of all varieties. Own root plants, 2 to 3 feet, $\$ 2.00$. 3 to 4 feet, $\$ 3.00$.

\section{Pink Varieties}

Senator Volland. Double, very floriferous. A very pretty lilac with a large bloom that is somewhat open. When in the bud the reverse of the petals shows a very distinct bright touching of pink which continues to show as the florets open and gives a very dainty effect to the bloom. Center of florets pinkish light lilac. Very dainty in its beauty. Strong own root plants, 2 to 3 feet, $\$ 2.00$. 3 to 4 feet, $\$ 3.00$.

Grace Orthwaite. Single. A beautiful single lilac that has the most real pink about it of any variety we know of. A very profuse bloomer, the bush being just one pink mass when in bloom. A real pink. Own root plants, 2 to 3 feet, $\$ 3.00$.

William Robinson. Double. As a rule people like this variety unusually well, and always pick it out as one of the best. Panicle very compact and almost round. The bloom when the florets are just about to open gives a very striking pinkish red effect which gives place to a lavender as the florets open and their reverse side turns back. Very much admired. Own root plants, 2 to 3 feet, $\$ 2.00$. 3 to 4 feet, $\$ 3.00$.

\section{Red Varieties}

Charles Joly. Double. Purple red. Charles Joly is one of the very best of the double dark reds. Bush medium both in size and height with limbs growing very upright. Blooms rather large, are held erect and make a very striking appearance as they show well above the foliage. This we consider the best of our entire list of double rèds. Own root plants, 2 to 3 feet, $\$ 3.00$.

Charles Tenth. Single. One of the most dependable of the single red lilacs. A very thrifty growing bush that begins blooming very young and produces large quantities of large, nicely shaped panicles. Own root plants, 2 to 3 feet, $\$ 1.00$. 3 to 4 feet, $\$ 1.50$.

Leon Simon. Single. A broad spreading upright bush. Panicles of medium length, very compact, and of a deep wine red. Deeper in color than Charles Tenth. Own root plants, 2 to 3 feet, $\$ 2.00$.

Ludwig Spaeth. Single. Dark reddish purple. This is one of the oldest varieties that we have among the better lilacs and it is still one of the most striking and best. Panicles very long, narrow and perfectly cylindrical. As the plant ages the bloom becomes profuse. Blossoms produced well on the outside of the foliage which makes it very showy. Mr. Root, of Springfield Ohio, who has one of the finest collections of lilacs in this country, says of Souv. de Ludwig Spaeth. "Out of all my lilacs it is one of the very best." Own root plants, 2 to 3 feet, $\$ 2.00$.

Philomon. A very strong growing lilac that is one of the most floriferous of all the purplish red varieties. Panicles literally cover the bush when in bloom. Panicles large, compact, pure purplish red. Own root plants, 2 to 3 feet, $\$ 2.00 ; 3$ to 4 feet $\$ 3.00$.

Volcan. One of the most robust and shapely growing of all of the best lilacs. As near a true deep red as we have. Panicles which are very long, large, and shapely, come up well above the foliage. These panicles look rather open as they are in the bud stage but as they develop they open into one of the finest, most shapely, and largest of all these lilacs. We have but a few plants in this variety for sale as the demand for it is so great from people who see it on our grounds when in bloom that we seldom have any left. Own root, 2 to 3 foot plants, $\$ 4.00$. 


\title{
Lavender and Lilac Varieties
}

Charles Sargent. Double. Medium tall growing variety. Very shapely and vigorous plant. Color a beautiful light lavender. Very double flower with florets with long narrow pointed petals. Own root plants, 2 to 3 feet, $\$ 2.00$. 3 to 4 feet, $\$ 3.00$.

Hugo Koster. Double. One of the newer sorts and quite an improvement over older varieties of its color. Panicles very large, broad at base, and tapering nicely towards the top. Color a deep lavender with tracings of pink. Florets large and of great substance. Own root plants, 2 to 3 feet, $\$ 2.00$. 3 to 4 feet, $\$ 3.00$.

Michael Buchner. Double. A beautiful lilac differing from most varieties in the blending of its colors. As the florets open the center of each remains a deep lilac bordered with a broad outer edge of distinct lighter shades, making it a very striking variety from a distance. Own root plants, 2 to 3 feet, $\$ 2.00$. 3 to 4 feet, $\$ 3.00$.

Maurice de Vilmoran. Double. One of the truly great lilacs. The demand is so great we seldom have any to offer. But we will have a limited number of plants for sale this season. A tall upright grower. Panicles very long and nicely formed.
Color a soft lilac with lavender shadings. One of the very choicest. Own root plants, 2 to 3 feet, $\$ 3.00$. 3 to 4 feet, $\$ 4.00$.

Mme. Leon Simon. Double. Strong foliaged and strong upright growing plant. Panicles long, beautifully formed and held well up. Buds swell very large before they open and are a deep reddish pink on the reverse side. Florets open like little roses of a deep bluish lavender. Strong own root plants, 2 to 3 feet, $\$ 2.00$. 3 to 4 feet, $\$ 3.00$.

President Carnot. Double. One of the most profuse blooming of all. Panicles very large and regular in form, rather oblong and compact. Florets in the bud very large. Back of floret deep reddish blue, center bluish violet. Plant very vigorous and one of the most dependable bloomers. Own root plants, 2 to 3 feet, $\$ 2.00$. 3 to 4 feet, $\$ 3.00$.

Rubra de Marly. Single. This lilac in color is very much like the beautiful old lilac of our grandmother's garden. But there is a decided tinge of pink to it. Its panicle is larger, and it is a tremendous annual bloomer. Own root plants, 2 to 3 feet, $\$ 1.00$. 3 to 4 feet, $\$ 1.50$.

\section{Other Lilacs}

President Hayes. Single. A very decided improvement on the Persian Lilac. Bush strong and robust with splendid foliage, very floriferous, and with immense panicles of bloom of a deep even lilac color. Strong own root plants, 2 to 3 feet, $\$ 2.00$.

Persian Lilac. Single. Color mostly Lilac. One of the most graceful of all shrubs for landscape planting. Exceedingly fine for planting as individual shrubs and in great masses. There is no shrub that makes a finer tall hedge than does the Persian Lilac. Our Persian Lilac stock has a slight mixture in it and because of this we are offering it very cheap. Strong, 2 to 3 feet, $75 \mathrm{c}$. 3 to 4 feet, $\$ 1.00$. Where ordered in lots of 25 and $u p$ for hedging, price 30c each; for 2 to 3 feet and $50 \mathrm{c}$ each for 3 to 4 feet. This 3 to 4 foot grade is an extra select grade, very heavy.

If a tall hedge or screen is wanted nothing is more beautiful than Persian Lilac.
Lilac Japonica. The Japanese Tree Lilac. Can be grown in either tree or shrub form. We grow it as a shrub. Grows into a beautiful tall shrub or if trimmed into tree form, as a still taller tree. Beautiful smooth bark, leaves large and thick. Covered with great feathery plume-like creamy white blossoms late in the season after the other lilacs are gone. Fits into a yard planting either as a medium sized tree or as a very large shrub. Very hardy. Own root, 2 to 3 feet, $\$ 2.00$. 3 to 4 feet, $\$ 3.00$.

Villosa (Specie). White tinted pink. This is a most desirable lilac, not only on account of the beauty of the great feathery lacy-like panicles of bloom but also on account of the beauty of the plant itself. This variety is very robust and grows into a great shrub 8 to 10 feet tall. Its leaves are large, heavy and beautiful in appearance. It comes into bloom about a week after the regular lilac season is over, thus prolonging the season. Strong own root plants, 2 to 3 feet, $\$ 1.00$. 3 to $4 \mathrm{f}$ eet, $\$ 1.25$.

\section{Special Lilac Offers}

\author{
Special Lilac Offer "A"
}

Anyone choosing lilacs from the above list may choose $\$ 25.00$ worth for $\$ 20.00$.

\section{Special Lilac Offer "B"}

We will send one each of the following twelve beautifullilacs in strong 18 to 24 inch grade for $\$ 10.00$. Mme. Casimer Perier and Marie LeGraye, white; Charles X and Leon Simon, red; President Grevey and Alphonse Lavalle, blue; Sen ator Volland, pink; Rubra de Marley, pink; Villosa, late pink; and Japonica, white.

\section{Twelve Beautiful Lilacs All Different for \$10.00 Postpaid}

\section{Special Lilac Offer "G"}

We have over 30,000 small size lilac bushes in our storage in many varieties for our own spring planting. These will all be graded over before Spring planting time and many nice little sales plants selected out. We offer these in assortments of ten all good varieties, all colors, all different, all labeled at 10 for $\$ 7.50$ Postpaid. Two extra plants different from any of the above making twelve in all we will add to all orders received accompanied by the cash, if order is mailed to us not later than March 31 , 1930 . 


\title{
Beginners' Lilac Collection
}

There are many who are just about to start a collection of good lilacs. They are not familiar with varieties and so do not know what kinds to buy. To help such people out we are offering the following Beginners' Collection of four first class lilacs. All strong, 2 to 3 feet high.

\author{
1 Mme. Casimer Perier..... \\ 1 Senator Volland.. \\ 1 Charles X. \\ 1 President Grevey
}

All own root, all for $\$ 5.00$, Express Collect.

\author{
Double White \\ Double Pink \\ Single Purple Red \\ Double Blue
}

2 to 3 feet
2 to 3 feet
2 to 3 feet
2 to 3 feet

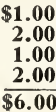

\section{Improved Philadelphus}

\author{
(Mock Orange or Sweet Syringea)
}

There has been wonderful improvement made of late years in that grand shrub, the Philadelphus, or as it is better known to us, the Sweet Syringea or Mock Orange.

The Lemoines of France, the same men who produced the most of our new Lilacs, are the ones who have produced these beautiful new Philadelphus.

The older varieties of Philadelphus are single. These new ones come in singles, semi-doubles and doubles. They are more beautiful than the older sorts in that their blooms are larger, are borne in greater prof usion and are of more exquisite form. These different Philadelphus may be selected as to their final growth in sizes to suit almost any want. Some varieties are real dwarf, others are of medium height, while still others grow into plants eight or ten feet high. The most of them are very sweet scented and of ten a single bush covered with its beautiful bloom will scent the air of an entire city block.

Albatre. This is a very showy variety with large, dense panicles of double pure white flowers. The plant is compact, bushy, and of medium height. When fully grown this variety is about five feet high. Strong 18 to 24 inch plants, 60 cents

Avalanche. Five feet. Pure white. Grows into a very attractive bush about five feet high. The branches are very slender and graceful, and when in bloom this is a wonderful shrub. The medium sized single florets literally cover the branches from top to bottom, making an absolute snow ball of the plant. The slender branches become so heavily laden with bloom that they bend over in all directions. We think this a very beautiful sort. 18 to 24 inch plants, 60 cents. Strong 2 to 3 foot plants, 75 cents.

Banniere. A tall shrub with long branches covered with a profusion of large semi-double snow white flowers. Extra fine and very early. The foliage is large and dark green. 18 to 24 inch plants, 75 cents each.

Bouquet Blanc. This variety forms an upright, shapely bush with dark rich foliage. Flowers come in clusters, are large, pure white, and quite double. Very sweet scented. One of the hardiest and most dependable bloomers. Extra choice. 18 to 24 inch plants, 60 cents each.

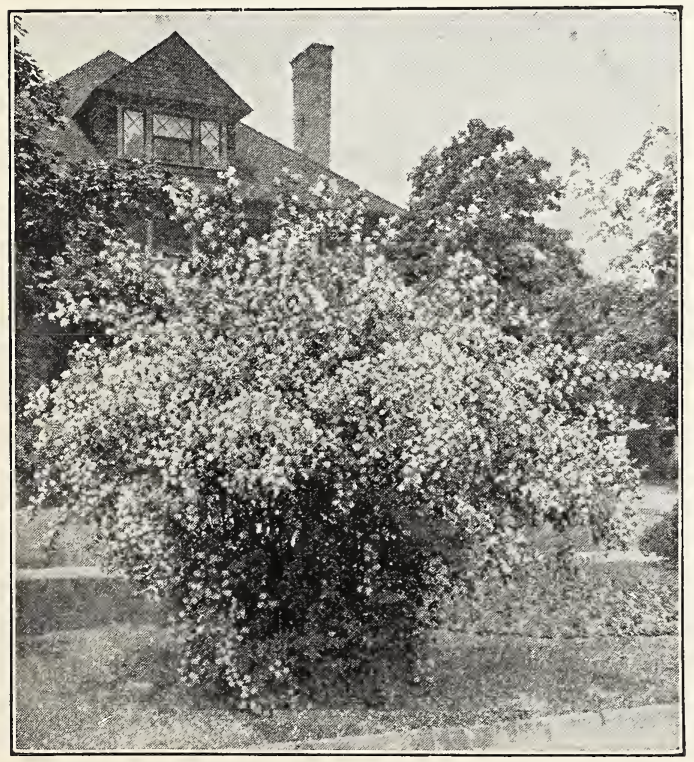

Dame Blanche. A very profuse blooming sort which produces large, semi-double flowers that are a rich creamy white. The bush grows about four feet high, is very shapely, and works nicely into border planting, into hedge work, or as a single specimen. 18 to 24 inch plants, 60 cents each.

Favorite. This variety produces very large flowers fully three inches across. These flowers are single, pure white, with a bunch of golden stamens in the center. The bush is an upright grower with rich glossy foliage. A marvelous flower. 18 to 24 inch plants, 75 cents each.

Glacier. We consider this variety one of the very best of the newest sorts. The flowers are wonderfully attractive in appearance. The blooms are produced in large clusters of six to eight, are double, and of a rich cream color. Grovis about five feet high. One of the choice kinds. 18 to 24 inch plants, 75 cents each.

Mt Blanc. A tall growing variety that works wonderfully well into a hedge to grow on a line between lots. Flowers large, pure white, and semi-double. Produced in wonderful prof usion. One of the most prolific bloomers of all. 18 to 24 inch plants. 60 cents each.

Norma. A strong growing variety that reaches a height of eight feet If it could be said that any one of these wonderful Philadelphus was more beautiful than the others, it would in our estimation be said of Norma. The flowers are of great size, single, with a rich waxy-like appearance. 18 to 24 inch plants, 60 cents each.

Ophelia. A rather dense growing bush with long branches that arch gracefully under their great loads of bloom. The flowers are of medium size and run from semi-double to full double. Pure white with crinkled petals. Grows about four feet high. Strong 18 to 24 inch plants, 60 cents each.

Pavillion Blanc. Beautiful flowers of the purest white, sweetly fragrant. Grows into a nice shapely bush about five feet high, of the most striking of all the Philadelphus. 18 to 24 inch plants, 85 cents each.

Pyramidal. A very nice shrub that takes up but very little space because of its narrow upright growtl. Nice to plant in corners about the house. Blooms large, semi-double, pure white, and very fragrant. Grows about four feet high. 18 to 24 inch plants, 60 cents each.

Virginal. Double. White. Ever-blooming. Taken all in all this is the most sensational of all the Philadelphus. In fact, we think it the most valuable acquisition to the flower garden made in recent years. The bush is a moderately strong grower, with us attaining a height of between six and seven feet. Rather of an open sparsely foliaged plant which permits its wonderful blooms to be all the better displayed. Flowers pure white, double, and often two inches in diameter. Begins to bloom about June 15 with us and gives a heavy crop of bloom for about three weeks. Then it rests a few weeks and then starts to bloom again and keeps it up with a small amount of bloom until frost. Strong 2 to 3 foot plants, $\$ 1.00$ each. 3 to 4 feet, $\$ 1.25$ each. 


\section{Special Philadelphus Collection}

These new Philadelphus lend themselves wonderfully well to group planting. A collection of all varieties would be most interesting. For this reason we are offering the entire list as our first collection.

Albatre

Avalanche

Banniere

Bouquet Blanc

Dame Blanche

Favorite

Glacier

Mt. Blanc

Norma

Ophelia

Pyramidalis

Pavillion Blanc

Virginal
18 to 24 inch

18 to 24 inch.

18 to 24 inch.

18 to 24 inch.

18 to 24 inch.

18 to 24 inch

18 to 24 inch

is to 24 inch.

18 to 24 inch.

18 to 24 inch.

18 to 24 inch.

2 to 3 foot
18 to 24 inch.
$\$ 0.60$

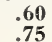

.75

.60
.60

.75

.75

.60

.60
.60

.60

.85

1.00

$\$ 8.90$

One fine strong plant of each of the above 13
kinds for $\ldots \ldots \ldots \ldots \ldots \ldots \ldots \ldots \ldots \ldots \ldots \ldots \ldots \ldots \ldots \ldots$

Six plants of any one variety for the price of five.

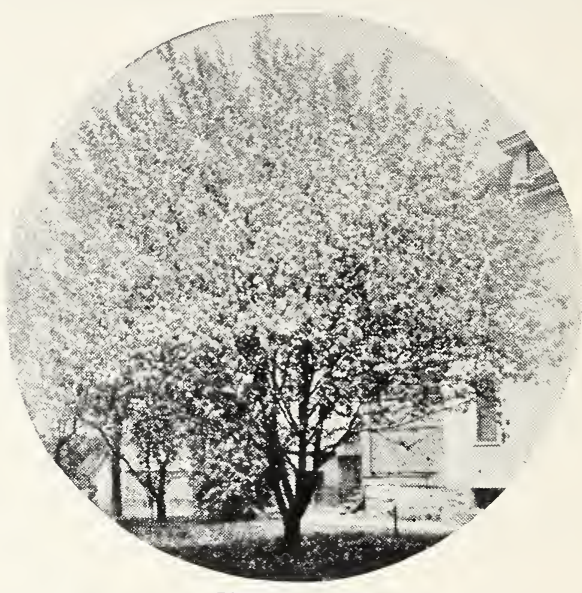

Flowering Crab

\section{Special Philadelphus Offer of Six for $\$ 3.50$}

\begin{tabular}{|c|c|c|c|}
\hline Albatre & 18 to 24 inch ........... $\$ \$ 0.60$ & Pyramidal & 18 to 24 inch.......... .60 \\
\hline Avalanche & 18 to 24 inch............ .60 & Virginal & 18 to 24 inch........... 1.00 \\
\hline Bouquet Blanc & 18 to 24 inch............60 & Norma & 18 to 24 inch........... \\
\hline
\end{tabular}

\section{Flowering Crabs}

It will bring great pleasure to many people to learn that those of us who live in the middle Northwest and in similar climates are now able to grow in our yards and gardens beautiful flowering crabs. The most of the flowering crabs which show up so beautifully in warmer and in some respects more favored climates will not do well with us.

That such a condition of affairs might not continue Professor Niels Hansen, of Brookings S.D. College of Agriculture, a wizard of Horticulture, set about the production of a line of absolutely hardy ornamental crabs. That he has succeeded is attested to by the many beautiful and hardy sorts which he has brought out. These crabs of Hansens which we offer below are all absolutely hardy and will do well in the Northern most limits for hardy apple tree growth both in the United States and Canada.

All varieties listed are very beautiful while in bloom. The trees are all very ornamental as lawn or garden trees after the bloom is gone and several of them set fruit which is very fine to eat or work up into sauce or jelly.

Beauty Crab (Hansen). A beautiful crab raised from seed received from the Botanical Gardens at Petrograd, Russia. Probably the brightest in color of all these crabs. A brilliant solid cherry red all over with orange red underneath. Dots distinct, few white. Makes a bright red sauce like that of the Hyslop without the astringency of the Hyslop. A beautiful tree and beautiful fruit, hence the name Beauty.

Bechtel's (Double Flowering Crab). Without exception probably the most beautifu! of all flowering crabs. A double form of the native wild crab. Grows about ten feet high. A hardy tree that during blooming season is covered with masses of beautiful double pinkish lavender flowers that look like pink roses. The perfume is simply exquisite. 3 to 4 feet, $\$ 1.00$ each. 4 to 5 feet, $\$ 1.50$.

Cathay. A round-topped dwarfish tree with much promise as an ornamental lawn tree. In bloom the tree is one immense bouquet of very large white flowers. The flowers are two and one-half inches in diameter, and occasionally come double.
The tree is mainly for ornament but produces a fair fruit of a clear yellow, one-half inch in diameter.

Dolgo. A beautiful upright very thrifty growing tree with nice clean light green foliage. Covered in spring with large pinkish white blooms which are followed by a wonderful crop of long conical shaped fruits which ripen in the fall and take on the most brilliant deep crimson color. These fruits hang on until late in the fall and make of the tree a marvelous ornament. The Dolgo is one of the greatest jelly crabs ever produced. The jelly gets the beautiful color of the peel of the crab and it will make the firmest of jelly after the fruit is dead ripe.

Hopa (Hansen). One of the most beautiful of the purely ornamental flowering crabs. The wood of the tree is a purple red. The inner bark is still redder. The new leaves are red, and the flowers as they appear in great profusion over the entire tree are red. Following the red bloom appear little crabs which are red all summer long. Absolutely hardy. The fruit is too small to be of value for eating but its bright red color makes the tree a beautiful ornament for the yard.

The above five Flowering Crabs are the only varieties we recommend for Minnesota, the Dakotas, Nebraska, Iowa, Wisconsin, and Northern Michigan. 
The following list of Flowering Crabs is recommended together with the above list for planting in states further south and east. Arnold's Crab. Originated at Arnold Arboretum. Forms a tree twelve to fifteen feet high. Covered with beautiful large rose colored flowers gradually turning to white.

Atrosanguinea. Carmine Crab. Matures at from eighteen to twenty feet. Very desirable on account of the rich deep red color of the flowers.

Dr. Van Fleet. Develops into a large tree twenty-five to thirty feet high. A vigorous grower and profuse bloomer. Flowers a beautiful pink.

Floribunda. Twenty to thirty feet. A hardy, vigorous spreading tree producing a profusion of deep pink flowers. The Japanese Flowering Crab.

Niedswetzkyana. A beautiful crab found growing wild in the mountains between western China and Turkestan. Purplered branches, leaves, stems, bark, buds, and fruit. Flowers intense red. Hardy in protected places in the north. Very satisfactory through the South and East.

Parkmani. Eighteen to twenty feet. A beautiful Japanese dwarf tree with long stemmed semi-double flowers of a deep rose red color. Very handsome in the bud.

Prices. We have Bechtel's Crab in 3 to 4 feet at $\$ 1.00$ and 4 to 5 feet at $\$ 1.50$. All other Flowering Crabs in nice 4 to 5 foot trees at $\$ 1.50$ each. One each of the eleven varieties, 4 to 5 foot trees, for $\$ 12.50$.

\section{Flowering Cherries}

A very beautiful line of small sized trees that are becoming tremendously popular all over the country wherever they can be grown. The greatest collection in this country is to be seen in the city of Washington, where the magnificent gift of Japan to this government is planted. It will well repay any flower lover to make the trip to Washington just to see these wonderful trees in bloom. Not hardy in Minnesota, Iowa, etc.

Kwanzan. A splendid late double pink. Very thrifty and beautiful tree with most lovely flowers. Nice 3 to 4 foot trees, $\$ 4.00$.

Kofugen. An upright growing tree. Crimson buds opening into wonderful flowers that are red fading to old rose. One of the very best. 3 to 4 foot trees, $\$ 5.00$.

Yoshino. Very fast growing spreading tree carrying beautifu single pink blossoms fading to white. 4 to 5 foot trees, $\$ 4.00$.

\section{A Flowering Cherry That is Different}

May Day Tree. The late Professor J. L. Budd, of Ames Iowa, many years ago imported some cherry trees for the State of Iowa from the Imperial Botanical Gardens of Russia and in this importation was this tree as a mixture. It is entirely different from any other Flowering Cherry that we have. It is absolutely hardy even on the prairies of the Dakotas. The May Day Tree is a bird cherry from Eastern Siberia and is worthy of a place on every lawn where the more tender Flowering Cherries cannot be grown. It is remarkable as the first tree to come into full leaf here. The large green leaves and wealth of white blossoms early in the spring make the tree decidedly ornamental. It also bears fruit which resembles our choke cherry. Nice 4 to 5 foot trees, \$1.50.

\section{Flowering Plum (Rose Tree of Ghina)}

Prunus Triloba (Double Flowering Plum). This is the shrub often sold under the name of "Rose Tree of China." A most beautiful shrub or small tree as it can be grown in either form. The most beautiful of all the flowering trees that is hardy enough for the middle north west. Grows into a bush or tree from eight to ten feet high. The branches are literally loaded in the early spring just as the leaves start to open with small very double rose-like flowers an inch in diameter, of an intense pink on the outside fading to the most delicate shell pink in the center. Probably the most striking and desirable of any of our very early flowering shrubs in this latitude. We have an unusually fine stock of Prunus Triloba this spring. 2 to 3 foo bush, 75 c; 3 to 4 foot bush, $\$ 1.00 ; 4$ to 5 foot tree, $\$ 1.00$ 5 to 6 foot tree, $\$ 1.50$.

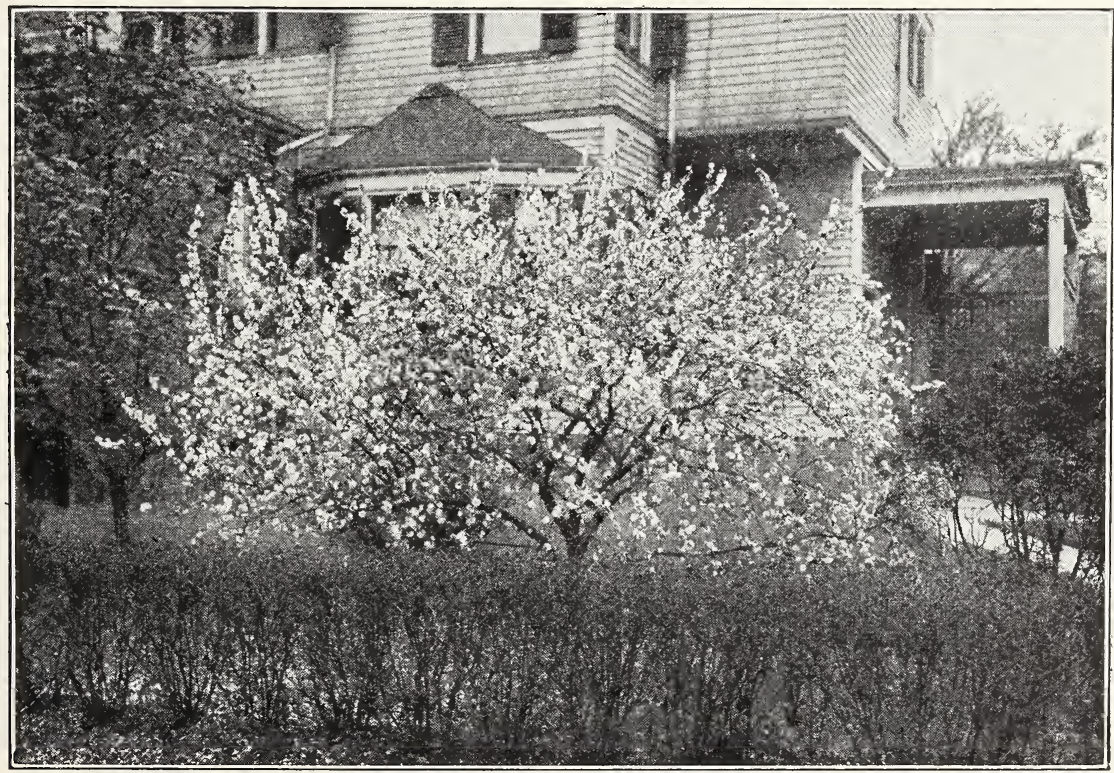




\section{Purple and Red Leaved Plums}

Prunus Newport. Matures into a tree fifteen to twenty feet high. This is the hardy purple leaved plum sent out by the Minnesota Fruit Farm. It is a hardy rather slow growing tree of great refinement. The leaves are smooth and richly colored, very red at first ripening to a deep bronze purple which is held all summer. 3 to 4 feet, $\$ 1.00$. 6 for $\$ 5.40$.
Prunus Cistena. Hansen's purple leaf plum. Grows to a height of five to six feet. This is the very desirable purple leaved plum sent out by Hansen and carries the blood of the sand cherry which dwarfs it and gives it the appearance more of a large shrub than of a tree. Leaves more red than Newport, and remain red all summer. 4 to 5 feet, $\$ 1.25$. 6 for $\$ 6.00$.

\section{Flowering Thorn}

Paul's Double Scarlet. A handsome dwarf tree with attractive shiney deep green leaves. It blooms late in the spring with compact clusters of deep crimson-scarlet flowers. This is one of the most attractive of the small flowering trees and is lesirable either as a single specimen or in groups. Hardy in favored protected locations in southern Minnesota. Nice 5 to 6 foot trees, $\$ 2.50$ each.

Minnesota Thorn. This is a selection of the native thorn or thornapple as it is commonly called which grows wild in Min- nesota. It is one of the most beautiful of all our small native trees. Can be trimmed into any shape desired, box, globe, pyramid, etc, Makes a beautiful hedge and one that no dog or boy can get through. Also beautiful as a small tree for the lawn or for clusters of trees in corners of large estates. Very beautiful in fall when loaded with its small edible red fruits. Hedge sizes and quantities matter of correspondence. Strong 2 to 3 feet, 75 cen ts. 6 for $\$ 3.50$.

\section{Other Ornamental Trees}

Catalpa-Bungeii. Grafted on stems five to six feet high, it makes an umbrella shaped top without pruning. Leaves large, glossy, heart shaped, deep green, over-lapping like shingles on a roof. Always makes a beautiful perfectly formed head. Usually planted in pairs on opposite sides of a walk. 5 to 6 feet, $\$ 1.75$ each. 2 for $\$ 3.00$.

Catalpa-Speciosa. A beautiful tree developing into a quick shade. Has very large heart shaped leaves and great panicles of white flowers, tinged violet, with dots of purple and yellow. Used extensively as an ornamental tree but also of great value for growing into fence posts. 5 to 6 feet, 75 cents. 6 for $\$ 3.50$.

Cut Leaf Weeping Maple (Wiers). A beautiful tree for lawn or street planting. A fast growing tree. A sport of the silver or soft maple. Has long graceful drooping brancies covered

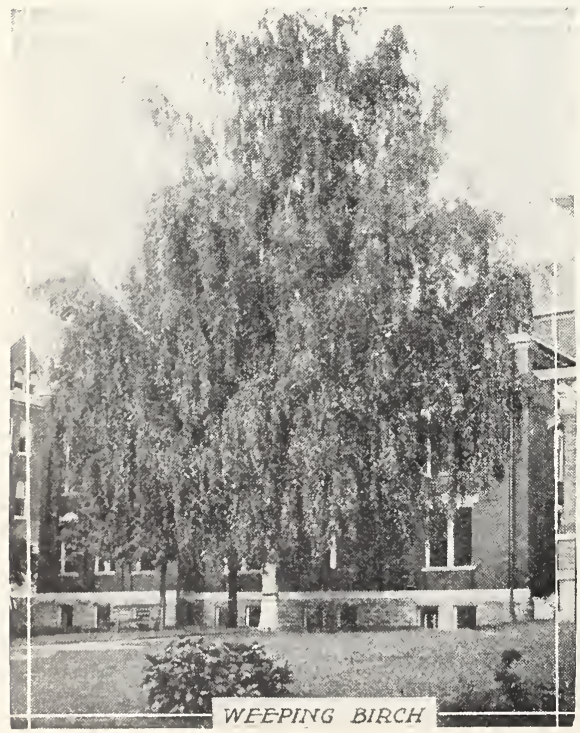

with finely cut leaves. One of the best of the weeping trees. Nice 5 to 6 foot trees, $\$ 1.00$.

Birch (Cut Leaf Weeping). The Cut Leaf Weeping Birch is the finest and most graceful of all the weeping trees. A most beautiful tree with cut leaves, long slender pendulous weeping branches, and white bark.

NOTE-In shipping out Cut Leaf Weeping Birch trees we always ball and burlap the roots the same as we do those of an evergreen. 6 to 8 foot trees, $\$ 3.50$ each. 2 for $\$ 6.00$ 8 to 9 foot trees, heavy, beautiful specimens, $\$ 5.00$ each. 2 for $\$ 8.00$.

Elm. (Minneapolis Park Board Selection). This is an Elm selected by Theodore Worth. Superintendent of Minneapolis Parks, as a standard type of Elm to be planted on the streets of the city of Minneapolis and in its parks. The city of Minneapolis is becoming famous as a city of beautiful streets and parks. And it is this selected Elm that is helping in a great measure to bring this about. These trees are budded to preserve the type. Fine 6 to 8 foot trees, $\$ 2.50$. 8 to 9 foot, $\$ 3.00$.

Elm-Moline. A new type of elm of fast growing habits. The growth is clean and thrifty with large luxuriant leaves of a dark rich shade of green. These elm are developed by budding and so are of uniform type. Where Elm is used as a street tree it is desirable to have all the trees look alike. To obtain this result one must plant either the Minneapolis Park Elm or the Moline Elm. Both are budded trees and so all trees are alike. This Elm is hardy through Iowa, Illinois, Southern Wisconsin, Michigan, etc. Beautiful 6 to 8 foot trees, $\$ 2.00$. 8 to 10 feet, $\$ 2.50$.

Elm (American White). Where a great spreading hardy, long lived tree is wanted plant American White Elm. The White $\mathrm{Elm}$ is the greatest of all American trees. Tall, fast growing, graceful, all that could be desired in a tree. 5 to 6 feet, 75 cents, 10 for $\$ 6.00$. 6 to 8 feet, $\$ 1.00,10$ for $\$ 7.50$.

American Linden (Basswood). One of our finest lawn trees and in certain sections a most beautiful street tree. A tree that grows to be one of our largest trees. Very symmetrical shape, broad at the base and tapering gradually to the top. Immense dark green leaves. Very fine. Fine 6 to 8 foot trees, \$1.50. 


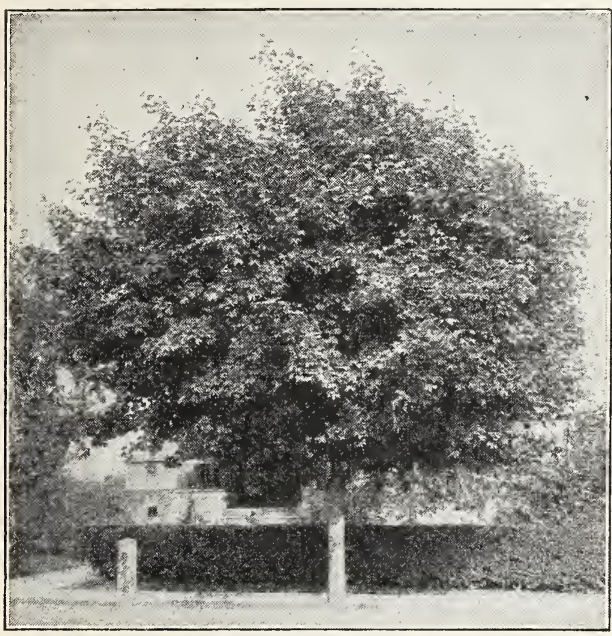

Norway Maple

Poplar-Bolleana (Silver Leaved). Very similar in habit of growth to the Lombardy and used in similar situations as that Poplar in planting. A very desirable tall spire-like growing tree with beautiful dark, maple-like leaves which are lined underneath with silver. Often used to fill out as corner backgrounds and to blot out high blank walls of neighboring buildings. 6 to 8 feet, $\$ 1.75,6$ for $\$ 9.00$. 8 to 10 feet, $\$ 2.25$, 6 for $\$ 12.00$.

Poplar Lombardy. A tall, slender, upright growing tree much used in ornamental plantings. Splendid for lining driveways from the street into the buildings, for using as a skyline to the rear of the yard and for placing here and there in corners against the sides of buildings. 6 to 8 feet, 75 cents, 10 for $\$ 6.00$.

Weeping Willow. Wisconsin. One of the most graceful of all the weeping trees. Grows to be a large tree with long slender weeping branches. Very appropriate to plant in the neighborhood of fish or lily ponds. Likes water. Green bark. 5 to 6 feet, 75 cents.

Weeping Willow (Niobe). The Golden Weeping Willow. A Willow that resembles the Wisconsin Weeping Willow in almost all respects except that it has a rich golden bark. Hardier on high land where it does not grow too fast. 6 to 8 feet, 75 cents.

Persons wishing to make a large planting of trees, shrubs, vines, peonies, fruits, etc., should write us. We carry many items in large quantities and we are always willing to make very attractive reductions on quantity lots.
Maple-Norway. A native of Europe. A large, beautiful tree, with deep green, shining foliage. A most desirable tree for planting along streets, in parks or on the lawn. The Norway Maple makes one of the most beautiful trees that we have. It grows into a great round headed tree that produces wonderful shade. 5 to 6 feet, $\$ 1.00$ each, 6 for $\$ 5.00$. 6 to 8 feet $\$ 1.50,6$ for $\$ 7.50$.

Maple (Schwedlerii). Red leaved maple. In early spring for about a month while the trees are growing, the leaves are a bright red, from which color they gradually change to a purplish green. In autumn they turn to a beautiful yellow. One of the most beautiful of trees. Absolutely hardy in Minnesota. 6 to 7 foot trees, $\$ 2.00$ each, 6 for $\$ 10.00$.

Mountain Ash (European). A fine ornamental tree for the lawn, forming almost without pruning, a magnificent, fairly dense, well shaped head, which is covered from mid-summer till mid-winter with large clusters of beautiful scarlet berries, giving a brilliant color to the landscape. The foliage is very handsome. It is one of the choicest trees and deserves extensive planting. 5 to 6 foot trees, 75 cents each. 6 to 8 foot, $\$ 1.00$. 8 to 9 foot trees, $\$ 1.25$. Six trees for the price of five.

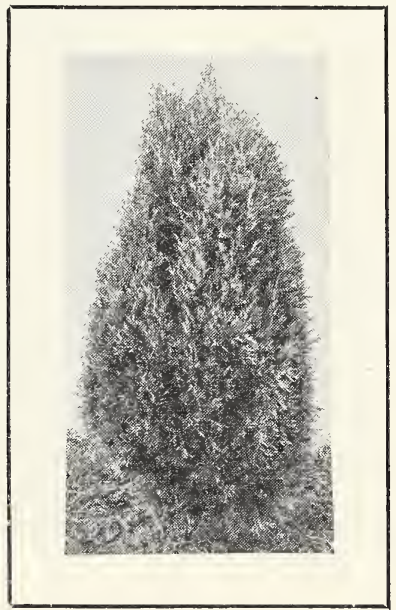

Pyramidal Arbor Vitae

Pyramidal Arbor Vitae. A beautiful and upright growing form of the Arbor Vitae. A superb evergreen, nice to plant in tubs to grow on each side of the porch entrance. A tree eight feet high will not be over eighteen inches in diameter. Fine $21 / 2$ to 3 foot trees balled in dirt $\$ 3.00$ each, 2 for $\$ 5.00$.

\section{Ornamental Shrubs}

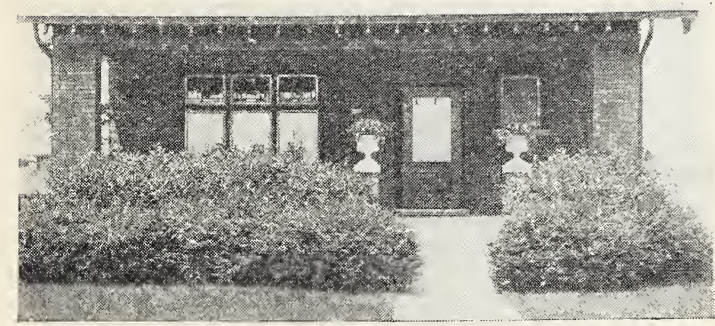

Barberry (front) and Mock Orange (rear)
Berberis Thunbergii (Japanese Barberry). This Barberry is not subject to rust. One of the best all around shrubs for the Northwest, thriving under all conditions. Slender, graceful branches with fine bright green foliage, turning to brilliant crimson and orange in fall. Branches are covered with small yellow flowers in June, followed by scarlet berries that stay on the bushes almost all winter. This is the best low hedge for the Northwest

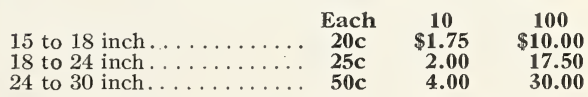

The above is all heavy transplanted, three year old stock and in either grade makes nice individual or hedge sizes. 


\section{SPECIAL HEDGING SIZE BARBERRY}

9 to 12 inch, 1 year old. 10 for $\$ 1.00 ; 25$ for $\$ 2.00$; 100 for $\$ 5.00$, Postpaid.

Box Barberry (Berberis Thunbergi Minor). A variation selected from the regular Japanese Barberry. It inherits all the good qualities of its parent as to hardiness, freedom from rust, etc., but is a dwarf grower with very fine twiggy limbs that form an evenly compact head that bears a striking resemblance to boxwood. Very desirable where a miniature hedge is wanted. From eight inches to a foot high and not over the same in width. Can easily be kept trimmed into square or globe specimens. Extra fine 12 inch plants, xxx 60 cents each, 10 for $\$ 5.00,100$ for $\$ 45.00$.

Cornus Siberica (Red Siberian Dogwood). Tall, spreading shrub, which is extremely hardy, and splendid for hedges or groups of shrubbery. Panicles of white flowers in June are followed by clusters of berries. Its chief beauty, however, is in its bark, which turns bright crimson as autumn approaches and remains a brilliant red all winter. Much used in hedges for its winter effect, 18 to 24 inch hedge size, $\$ 20.00$ per 100 3 to 4 feet $x \times x 50$ cents each, $\$ 40.00$ per 100 .

Honeysuckle (Upright Pink Tartarian). A favorite shrub. that is absolutely hardy even in dry states like the Dakotas and Vontana. Grows from eight to ten feet high, is splendid for individual shrub planting where a tall shrub is wanted. Fine to use as a screen to shut off the vegetable garden or unsightly buildings. Covered with a myriad of light pink blooms. 3 to 4 feet, $x x x 50$ cents each, 10 for $\$ 4.50$.

Hydrangea Paniculata Grandiflora. The most beautiful and striking of all flowering shrubs. Bears immense clusters of creamy white flowers in August, turning to bright pink and rose, and finally to bronze in September. Grows five to six feet high, does weil in sunny locations. Valuable for specimen planting and for borders, and should be in every garden. Should be cut back in spring before growth starts. The flowers dry like everlastings and can be kept indoors all winter. The plants are as hardy as the oak. Splendid for hedges. 2 to 3 feet $x \times x 50$ cents each, 10 for $\$ 4.50,100$ for $\$ 35.00$. Strong mail size 25 cents each, 10 for $\$ 2.00,100$ for $\$ 18.00$.

Hydrangea Arborescens (Hills of Snow). This is the early blooming outdoor Hydrangea. It comes into bloom just after the early spring flowers. The branches are well clothed in large, beautiful deep green leaves and each branch is terminated with a great glistening snow white bloom of immense size. Does best in partial shade. One of our best shrubs. Strong 2 foot plants, 50 cents each, 10 for $\$ 4.50,100$ for $\$ 35.00$. Strong mailing size, 25 cents each, 10 for $\$ 2.90,100$ for $\$ 18.00$.

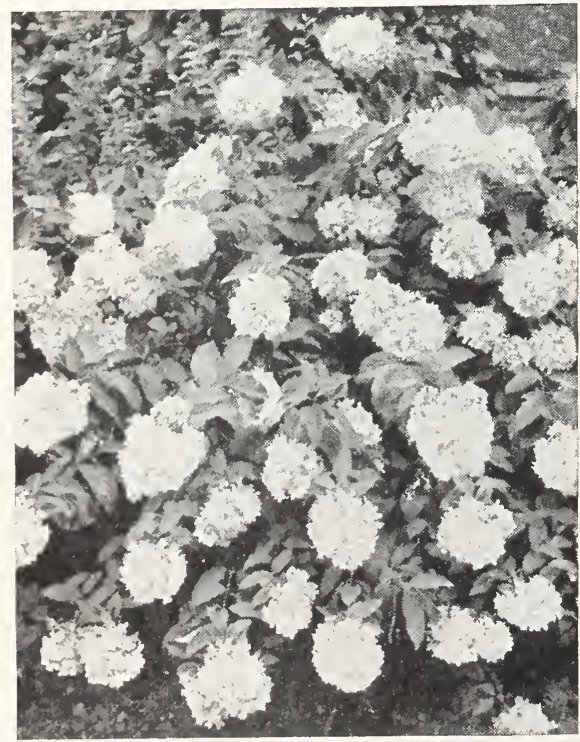

Hydrangea Panicula:a Grandiflora

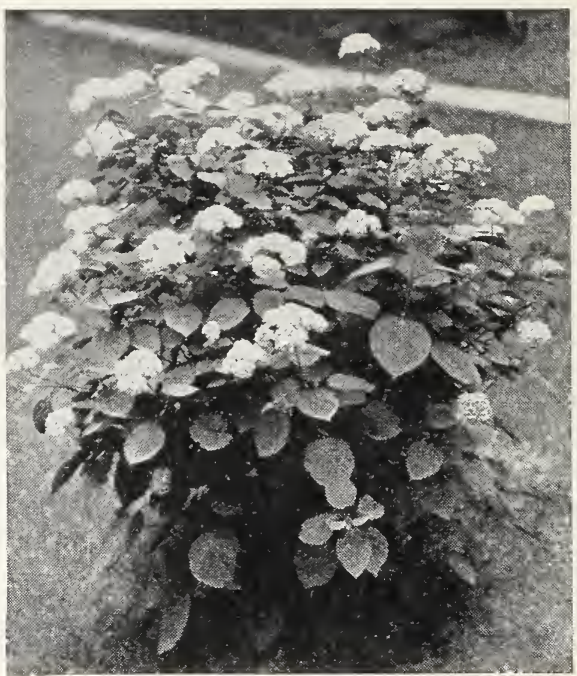

Hydrangea Arborescens

\section{Spireas}

Anthony Waterer. One of the finest flowering shrubs of low, dwarf growth. In constant bloom from June to September. Flowers of bright rose are borne in broad flat clusters, completely covering the bush. The best shrub for low borders and hedges. 12 to 18 inches, 50 cents each, 6 for $\$ 2.40$.

Arguta. The Garland Spirea. A perfect mass of tiny white flowers before the leaves fully appear early in the spring crowd the graceful pendant branches making it very showy at a time when very few flowers are in bloom. 2 to 3 feet, 50 cents each, 6 for $\$ 2.40$.

Aurea. A beautiful, tall growing Spirea covered from early spring until late fall with deep yellow leaves. This added to the pronounced yellow bark of the shrub makes it a very attractive plant on the lawn or about the house. 3 to 4 feet, 50 cents each, 6 for $\$ 2.40$.

Collosa Alba. One of the dwarfest of the spireas. Pure white flowers are borne in full flat clusters all over and entirely covering the bushy dwarf shrubs. Bright green leaves show between the flowers. Splendid to use with Anthony Waterer in front of taller shrubs.

Froebeli. A dwarf plant similar to Anthony Waterer but a little taller, with broader leaves. Bright crimson flowers during July and August. The tips of the leaves are a reddish purple. Very hardy. Much used for low hedges, as it is very hardy, compact growing, and a great bloomer. 18 to 24 inch 30 cents each, 12 for $\$ 3.00,100$ for $\$ 15.00$.

Prunifolia. This is one of the old fashioned spireas that is all too seldom seen in our gardens as it is probably the most beautiful of all. The flowers which are borne close to the slender erect branches early in the spring before the foliage appears, are glistening white and look like miniature roses. Very choice. 2 to 3 feet, $50 \mathrm{c}$ each.

Sorbifolia. A Splendid Spirea growing to a height of about five feet covered with large, clean bright green leaves that resemble the leaves of the Mountain Ash. Produces a world of great white feathery blooms about six inches long by four inches in diameter. A splendid Spirea to plant about the house. 2 to 3 feet, 50 cents each, 6 for $\$ 2.40$. 


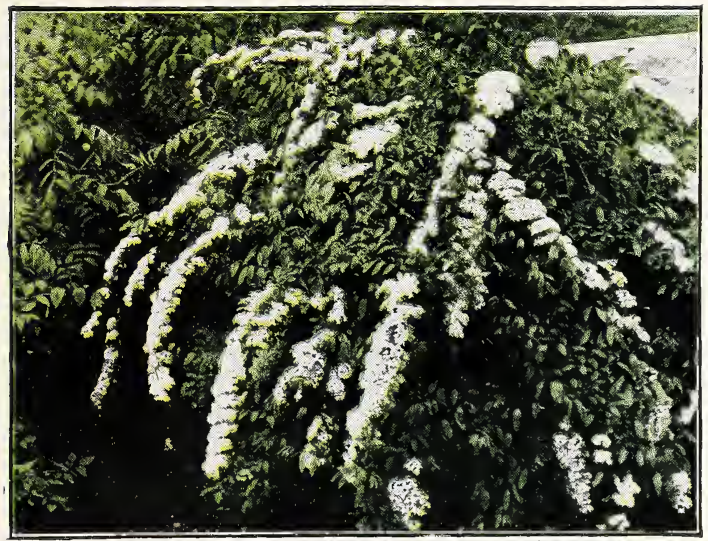

Korean Bridal Wreath-Spirea Trichocarpa.

\section{Korean Bridal Wreath}

\section{(Spirea Trichocarpa)}

A handsome new Spirea that comes to us as one of the many new things coming out of that strange country, the mother of so many good new plants, Korea. It has larger flowers than the common Bridal Wreath, Spirea Van Houttei, and the individual florets each have a distinct eye which gives the bloom much more effect. It is absolutely hardy here in Minnesota and starts to bloom heavily on two-year-old plants. The plant grows very fast and soon develops into a beautiful specimen. We are sure that this is the best new Spirea that has come to us in many vears. Blooms snow-white with a yellowish white eye.

Strong, 2 to $3 \mathrm{ft}$., $\$ 1.00$ each; 10 for $\$ 9.00$.

\section{Double Flowering Almond}

Pink. A beautiful May-flowering shrub that grows four feet high. Should be planted in a sunny place. Does especially well planted close to the south side of buildings. The branches are covered just as the leaves begin to come, with small, very double, rose-like flowers that are deep pink. Very showy. One of our most beautiful shrubs. All our Almonds are either on their own roots or are budded on the root of the wild plum. This makes them absolutely hardy. One or more of these should be in every yard as they bloom so early in the Spring that they are about the only shrub that we then have that will give us a touch of color to liven up the drab Spring landscape.

We call attention to our XXX grade. These are all really selected specimens and are very choice.

2 to $3 \mathrm{ft}$., $75 \mathrm{c}$ each; 6 for $\$ 4.00$. 3 to $4 \mathrm{ft}$., $X X X, \$ 1.00$ each; 6 for $\$ 5.50$.

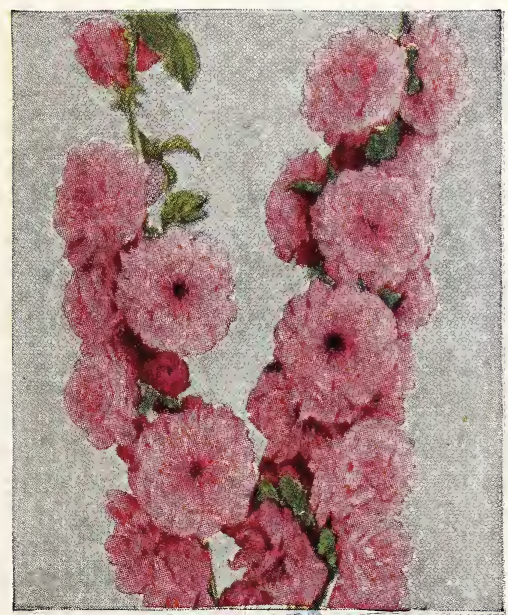

Pink Flowering Almond.

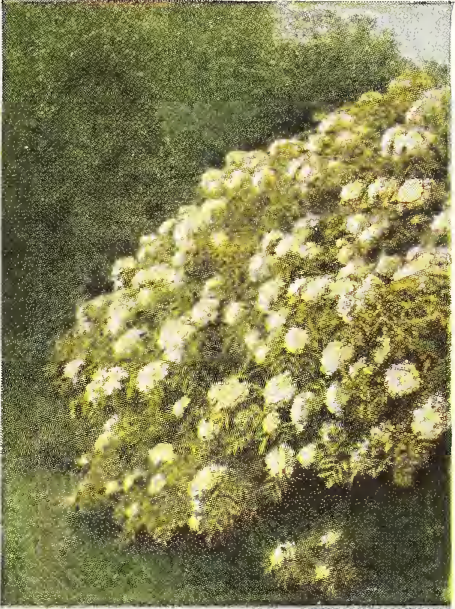

Golden EIder.

\section{Golden Elder}

\section{(Sambucus Aurea)}

A very striking shrub similar to the common American Elder in appearance with the exception of the color of the leaves, which are a beautiful bright gold from their first appearance in the Spring until they drop in the Fall. The best of our golden leaved shrubs.

The Golden Elder is the best shrub to plant where a golden effect is wanted. The color is a so'ft tone of yellow of which one never becomes tired.

3 to $4 \mathrm{ft}$., $\mathrm{XXX}, 50 \mathrm{c}$ each; 6 for $\$ 2.50$.

\section{Bechtel's Double Flowering Crab}

Without exception probably the most beautiful of all flowering Crabs. A double form of the native wild Crab. Grows about 10 feet high. A hardy tree that during blooming season is covered with masses of beautiful double pinkish lavender flowers that look like pink roses. The perfume is simply exquisite.

In Minnesota the Bechtel grows to a height of 12 to 14 feet while in southern lowa they develop into a tree 20 feet high.

We wish to' call especial attention to our 3 to $4 \mathrm{ft}$. XXX grade. Every one of these is a specimen tree selected for the most critical buyer.

2 to $3 \mathrm{ft}$., $75 \mathrm{c}$ each; 3 to $4 \mathrm{ft}$., XXX $\$ 1.00$ each.

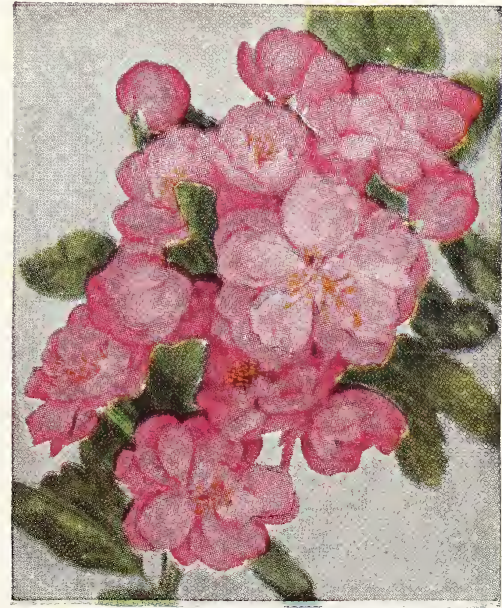

Bechtel's Double Flowering Crab. 



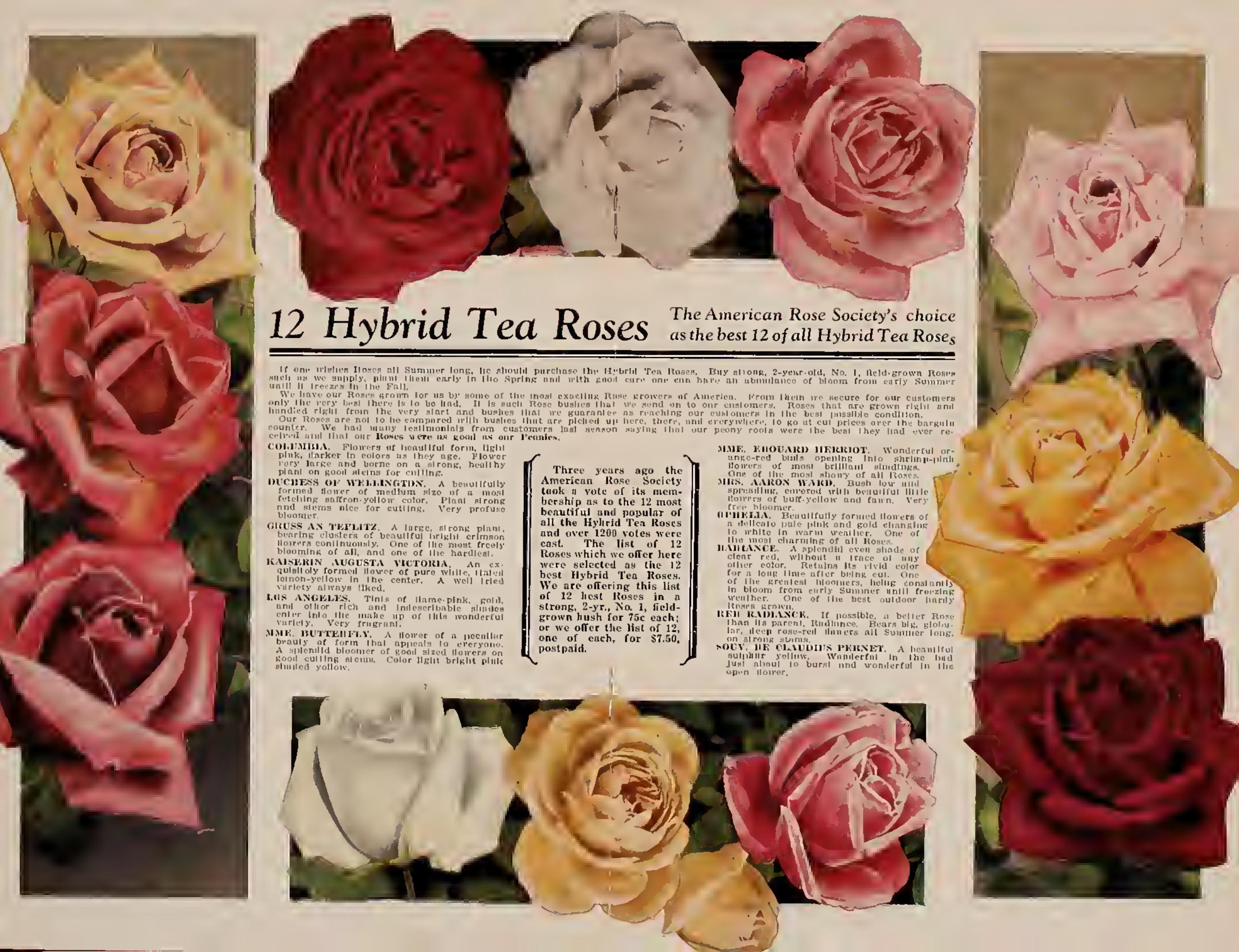




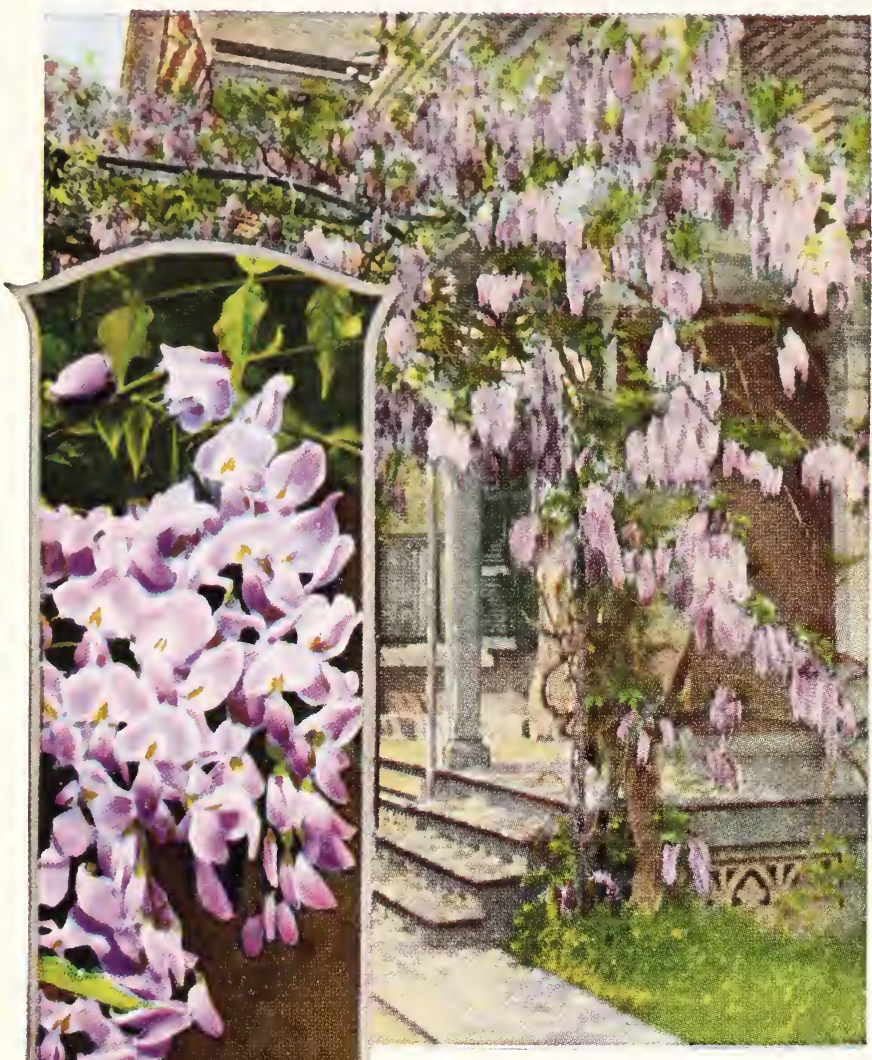

Purple Wisteria.

\section{Climbing Vines}

AMPELOPSIS Engelmanni (Engelmann's Ivy). A type of the Virginia Creeper, but different in growth as well as foliage. It has much shorter joints, and very much smaller and thicker foliage. This is the only hardy Ampelopsis that will cling to brick, stone or plaster. A fast grower. 30c each; 5 for $\$ \mathbf{1 1 . 3 0}$.

DUTCHMAN'S PIPE or ARISTOLOCHIA. The flowers in shape are similar to the old-fashioned Dutch pipe. Is a rapid climber and does best on the north side of houses, where the full force of the sun does not strike them. Better not plant too far north; blooms in June. 80 c each; 5 for $\$ 3.50$.

BITTERSWEET (Celastrus scandens). Perfectly hardy, rapid growth. Handsome glossy foliage. Large clusters of beautiful orange-crimson berries that are retained all Winter. The berries are in great demand for inside Winter decorations. We do not know of any vine that is more satisfactory. It is exceptionally fine for trellises and porches. If you wish something to give a little color to your trees, plant one at the base of the shade trees. This vine seems to do better on trees than other vines. 35c each; 5 for $\$ 1.35$.

CLEMATIS, Madame Edouard Andre. Has been called the crimson Jackmani. This plant is a strong, vigorous grower, very free in bloom, lovely flowers of a distinct crimson color. Different from all other varieties. 80 c each; 5 for $\$ \mathbf{3 3 . 5 0}$.

CLEMATIS Jackmani. Well known, large flowering blue Clematis, flowers almost violet with a rich velvety appearance, distinctly veined. Blooms from July until frost. Plant is hardy. 80 c each; 5 for $\$ \mathbf{3 . 5 0}$. CLEMATIS IIenryi. This is the finest of all large flowering, white Clematis. A vigorous grower and free bloomer. Flowers large,

creamy white with reddish chocolate anthers. 90c each.

CHINESE FLEECE VINE. (Polygonum Auberti). Rapid growing with small, bright green leaves and sprays of delicately beautiful lacelike flowers. Delightful. 2-yr., $\$ 1.00$ each; 5 for $\$ 4.50$.

PURPLE WISTERIA. Where the Purple Wisteria can be successfully grown it is probably the most thought of of all the climbing vines. The vines should be planted in a protected spot where the hard winds of Winter do not strike them. In such places, even in Southern Minnesota, they do well, provided one plants grafted vines. Many Wister as, although they grow vigorously, do not bloom. The reason for this is that many Wisterias that are sold are grown from seed and most seedling Wisterias do not bloom well. Our Wisterias are all grafted plants from strong blooming vines and are sure to bloom. The Purple Wisteria is the prettiest of all, and bears in great profusion, long clusters of pea-shaped blooms. Flowers come in May and June.

Strong, grafted vines, $\$ 1.25$ each; 2 for $\$ 2.00$.

\section{BEAUTY BUSH}

\section{(Kolkwitzia amabilis)}

An exceedingly handsome shrub that has come to us from the wilds of central China. The foliage and habit are attractive even when the bush is out of bloom. It is hardy with us here in Minnesota. It grows 6 to 9 feet high when fully grown and as far through. Erect growing, with twiggy branches, producing long arching limbs, covered in early Spring when the Iris are in bloom with clusters of small tubular blooms of weigela type flowers, but is far more beautiful than any weigela and is destined to become one of our greatest shrubs.

This season I again saw Beauty Bush in full bloom and the more I see of this shrub the more I am convinced that it is one of the most beautiful things I have ever seen.

Strong, 2-year, field-grown plants, $\$ 2.00$ each.

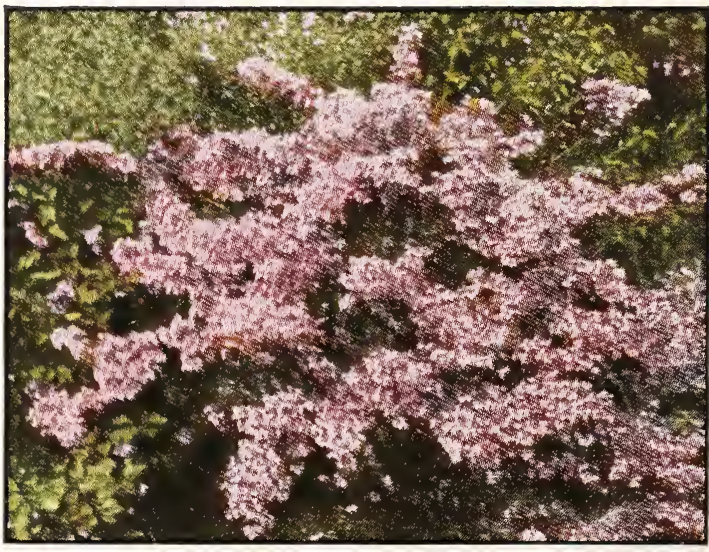

Kolkwitzia-Beauty Bush. 


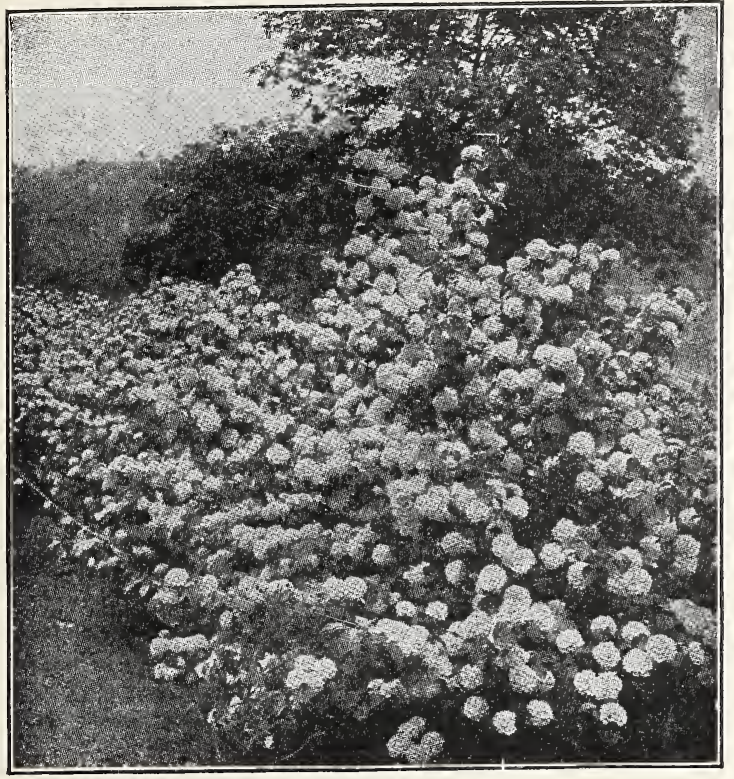

Snowball
Van Houttii. One of the finest shrubs ever produced. Its good qualities and beauty cannot be exaggerated. Very graceful, with lovely foliage growing four to six feet tall; extremely hardy everywhere. In May and June the whole bush is simply covered with small clusters of minute white flowers. For lawn and cemetery planting and for hedges, it cannot be equalled. It is the most popular shrub in all America. Strong hedging size, 25 for $\$ 4.00$; 50 for $\$ 7.50 ; 100$ for $\$ 12.00$. 2 to 3 feet, 25 cents each; 50 for $\$ 10.00 ; 100$ for $\$ 18.00$. 3 to 4 feet, Extra Select, 50 cents each; 10 for $\$ 4.00 .4$ to 5 feet Extra Select Specimen Plants, $\$ 1.00$ each; 12 for $\$ 10.00 x x x$.

\section{SPECIAL}

HEDGING SPIREA VAN HOUTTII

OFFER

25 for $\$ 2.50 ; 50$ for $\$ 4.50 ; 100$ for $\$ 8.00$

Snowball. A good shrub extensively used clear across the northern border of the country. Grows from eight to twelve feet high. Covered with dark green foliage and during the blooming season with great large, pure white snowball-like blooms. Strong 2 to 3 foot plants, 50 cents, 3 to 4 foot, 75 cents.
Snowberry Red. Coral Berry. Very pretty shrub to use in plantings in front of Hydrangea, the taller spireas, and to plant with barberry. Grows about three feet high, graceful branches, covered with minute red seed pods in ropes. Very pretty. 2 to 3 feet, 30 cents each; 10 for $\$ 2.50$.

Snowberry White. Another shrub that grows about three feet high and works in nicely with other shrubs of its height. Covered in the fall and well into the winter with numerous white seed pods which are very noticeable. 2 to 3 feet, 30 cents each; 10 for $\$ 2.50$.
Vibernum Dentatum. One of the prettiest of the entire Vibernum family. Noted for the neat appearance of the shrub covered as it is with its broad, bright green leaves that shine as though varnished. Most desirable as a permanent shrub. 2 to 3 feet, 50 cents each; 10 for $\$ 4.00$.

Weigelia. Eva Rathke. The hardiest of all the Weigelias. Extremely hardy with us here in Minnesota. We cannot say this for the other Weigelias. A dwarfish growing shrub whose branches are covered with bright red trumpet-like flowers. 18 to 24 inches, 60 cents each; 2 to 3 feet, 75 cents each.

\section{Fruit Bearing Shrubs}

There are several very desirable fruit bearing shrubs which are found growing in the woods throughout this locality which are among the most desirable of our ornamental shrubs and which at the same time produce large crops of fruit which is most desirable itself.

In early times when this territory was opened up there was found growing in certain localities in our woods, great quantities of Dwarf Juneberry and High Bush Cranberry. It was a fortunate thing that such was the case as those who pioneered this country had little with which to buy and on the other hand in those early days on the frontier there was little in the line of fruit offered for sale.

This scarcity of cultivated fruit did not deter the good housewives of those olden days, and long fruit gathering trips were made into the woods to gather Juneberry and Cranberry when these wild fruits happened to be ripe. And the shelves in many a pioneer's cellar would have been mighty bare during the winter time were it not for the abundance of these two fruits during the summer in the adjacent timber.

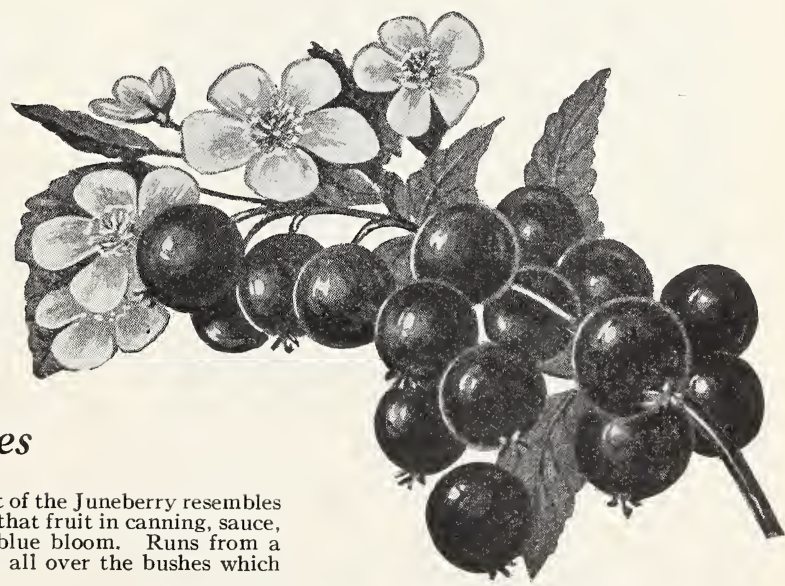

\section{Dwarf Juneberries}

A very desirable fruit for garden planting. The fruit of the Juneberry resembles very much the blueberry and is used in the same way as that fruit in canning, sauce, and making pies. Fruit round, black, with a heavy blue bloom. Runs from quarter to a half inch in size. Borne in great clusters all over the bushes which grow to a height of two feet. 
We have grown the Juneberry for many years in our nursery here for the fruit and find that it is one of our most dependable berries. It bears great crops every year and we enjoy it very much in pie and also put up and used in the winter for sauce. It is a sweet fruit with almost a total absence of acid and so must be made up with lemon to give it a tempting flavor.

Twelve bushes makes a nice planting, also makes a very nice ornamental shrub. Not only desirable as a small fruit plant but is beautiful as a small growing ornamental shrub for the border. A single plant dotted here and there among other shrubs gives them added life very early in the spring. Twelve plants will make a nice fruit planting but twenty-five is better. Three strong plants, $\$ 1.00 ; 12$ for $\$ 3.00 ; 25$ for $\$ 5.00 ; 100$ for $\$ 18.00$. High Bush Cranberry A large growing shrub that resembles very much the bush of the snowball. Leaves redden up in the fall and are very beautiful. The white flowers are not of great beauty but they are followed by a profusion of bright red berries in large clusters which hang on way into the winter and make a wonderful lawn ornament. These berries are fine for culinary purposes and make a jelly that looks and tastes exactly like that of the marsh cranberry, such as one buys at the grocery.

Nice to plant as individual shrubs, or in clusters, or in long rows as a background. Grows to a height of from eight to twelve feet, and old bushes will often bear a bushel of fruit in a single year. If planted on the farm where there is plenty of room, nothing is nicer than a full row of Cranberry planted along the north side of the garden where it will produce loads of fruit and at the same time act as a dense low windbreak for the garden. So planted bushes should be set six feet apart in the row. 18 to 24 inches, 50 cents; 10 for $\$ 4.50,20$ or $\$ 8.00$. 2 to 3 feet, 75 cents; 10 for $\$ 7.00 ; 20$ for $\$ 12.003$ to 4 feet, $\$ 1.00 ; 10$ for $\$ 9.00 ; 20$ for $\$ 17.50$.

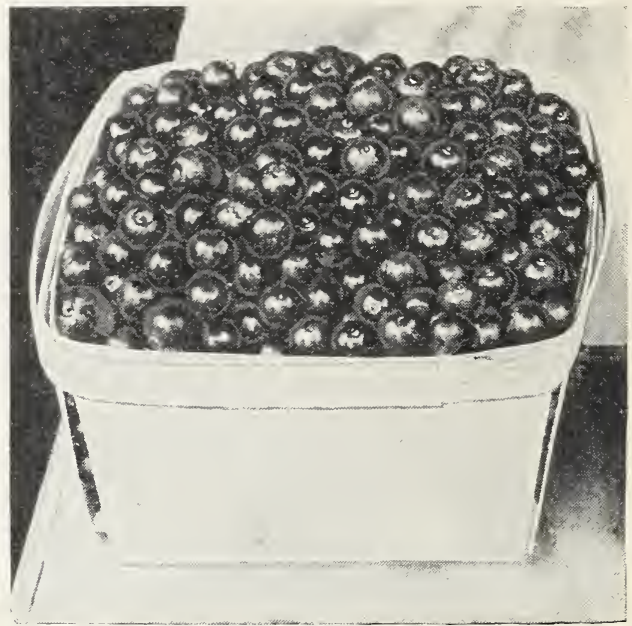

Juneberries in the Box

\section{Lilies}

Lilies succeed best in a light sandy or light loamy soil if the bed is sufficiently enriched and well drained.

Lilies like well rotted cow manure and leaf mold worked thoroughly into the soil before planting and a subsequent dressing of well rotted cow manure as the soil in after years needs fertility.

Auratum (Gold Banded Japan Lily). Flowers very large, with broad petals gracefully curved back. White with many crimsonmaroon spots, and a wide gold band down the center of each petal. Extra large, 50 cents each; 3 for $\$ 1.25 ; 12$ for $\$ 5.00$. Elegans A group of very hardy Japanese Lilies that come in different shades of reds and yellows. These Lilies grow to a height of $11 / 2$ to 2 feet and are very nice to work into rock gardens. Mixed, each, 25 cents; 3 for 70 cents; 12 for $\$ 2.50$. Henryi (Yellow Spèciosum). Of strong vigorous growth, with flower stalks three to five feet long deep apricot-yellow, lightly spotted brown. One of the best of the hardy lilies. 75 cents each; 3 for $\$ 1.85$.

Speciosum Rubrum A most beautiful lily that blooms in August. A clear white background covered with ruby spots. A lily that is very much admired. Large size, 40 cents each; 3 for $\$ 1.00 ; 12$ for $\$ 3.85$

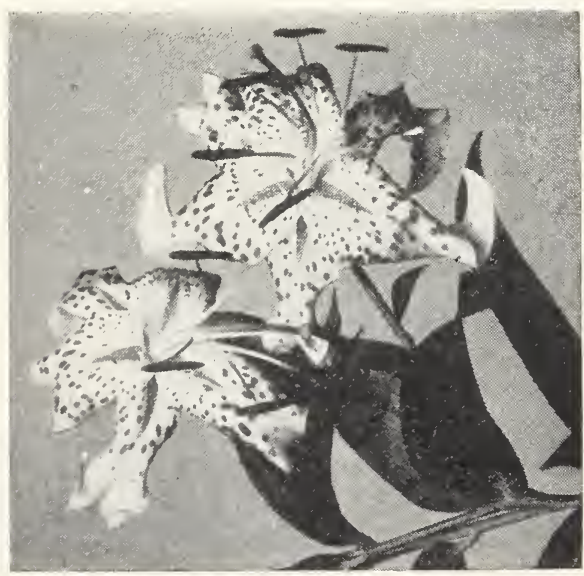

Superbum (American Turks Cap). The most showy of all the North American Lilies. A brilliant orange-scarlet, shaded yellow and spotted purple brown at the base, red anthers. A single plant will often carry forty large flowers. 25 cents each; 3 for 70 cents; 12 for $\$ 2.50$.

Tiger Lily (Splendens). The single variety. This is the hardiest of alllilies. When once planted they will grow on for a hundred years in the same place without moving. Orange-red flowers spotted purple on reflexed petals. Very late for a lily, blooms in September. Plant bulbs from eight to nine inches deep. First size buibs, 25 cen ts each; 10 for $\$ 2.00$

Tiger Lily (Flora Plena). Double Tiger Lily. This lily is almost identical with the single form except that it is just a trifle lighter in color. A wonderful pretty lily and the only true double. Handle same as the single. First size bulbs, 30 cents each; 10 for $\$ 2.50$.

\section{Other Perennials}

Aquilegia (Columbine). Mrs. Scott Elliott's Strain of Long-spurred Hybrids The blooms of this strain are of large size with very long spurs. The colors are all soft and clear, and range through blues, creams, mauves, pinks, lavenders, reds, whites, and yellows. The mixed colors when planted together make a wonderful and most pleasing blending of colors.

Strong plants, 3 for $\$ 1.00 ; 12$ for $\$ 3.25 ; 100$ for $\$ 20.00$.

Astilbe (Herbaceous Spirea). Beautiful plume-like plants for the perennial border. Must be planted in places protected from the wind. Cannot stand dry places. Like it where it is moist. Freule Van Den Bosch Beautiful dark pink. One of the newer varieties. Grows three and one-half feet tall. 75 cents each.

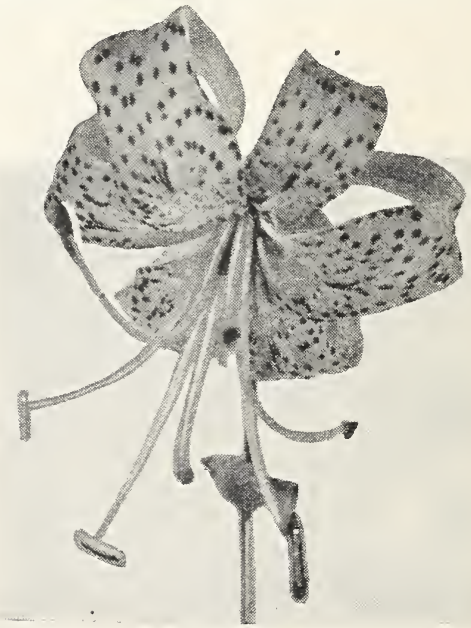

Lily Tiger 


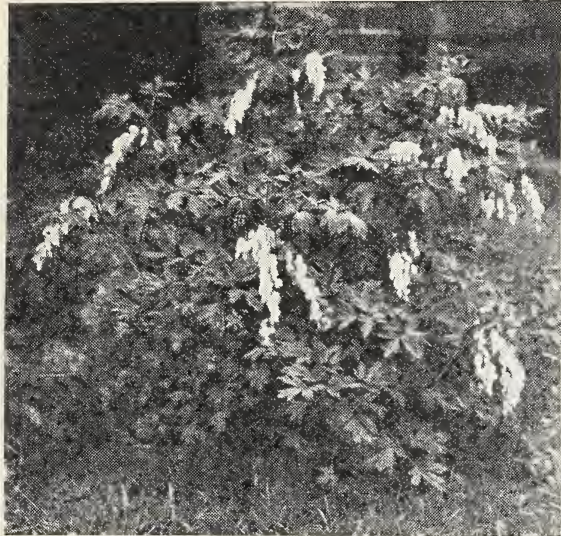

Bleeding Heart

Marguerite Van Rechteren. Bright red tinged with dark lilac. Tall variety growing to five feet. 70 cents each.

Gypsophila (Baby's Breath). Two to three feet, blooms in July and August. Small flowers on branched stems so thick as to give the plant a lace-like effect. Much used for working into bouquets with other flowers. When once planted do not disturb as they live for years. 3 for $\$ 1.00 ; 12$ for $\$ 3.00$.

Hibiscus (Mallow Marvels). Large beautiful shrub-like plants, with great handsome leaves, bearing throughout the summer, large brilliant open single flowers. We have an improved strain of Mallow Marvels. Some of the flowers measure as much as ten inches in diameter. Mallow Marvels will not come true from seed and each plant must be labeled as to color when it blooms. Plants in separate colors in Crimson Eye, Pink, Red, and White. 3 for 85 cents; 12 for $\$ 2.50$. Mixed Colors, 3 for 50 cents; 12 for $\$ 1.75$.

Hollyhocks. There is nothing more beautiful as a flower for a tall background for the garden than the hollyhock. They need but little care, are easy to get started and when once established will self seed and you have hollyhocks year after year in the same place, with but little effort. We have some very fine strains in separate colors in doubles. Plants in Red, Rose, White, Yellow and Maroon 3 for $\$ 1.00 ; 12$ for $\$ 3.50$.

Single mixed. Very fine strain, many most beautiful colors. This is actually the finest assortment of the Single Hollyhock that we have ever seen. 3 for 75 cents; 12 for $\$ 2.50$.

Hollyhock Seed. A splendid way to get a Hollyhock bed is to sow the seed broadcast in the spring so that the seed is from four to six inches apart. Cover it carefully and when it germinates keep clean all summer. By the next spring one has a wonderful showing of Hollyhocks. We have been breeding up our single strain of Hollyhocks for years and now have only the finest and most beautiful of colors the seed of which we are offering in large packages sufficient to plant a large bed for 25 cents postpaid.
Bleeding Heart. This is one of the old time flowers from Grandmother's Garden, that we will never tire of. The flower which are pink with a white center and heart shaped come in which are pink with a white center and heart shaped come in A valuable flower for planting in the shade. Very hardy and lives year atter year. Grows one to two feet tall and blooms in May. 50 cents each; 12 for $\$ 4.50$.

Physalis (Chinese Lantern Plant). Grows one and one-hal feet high. Flowers are yellow with a dark center. Produce balloon-like husks the second year, which turn bright red when ripe and resemble a. Chinese lantern. Very much used as a winter bouquet as these red lanterns will keep all winter. 3 for 60 cents; 12 for $\$ 2.00$.

\section{Viola}

Called Hardy Pansy. One of the best all around hardy perennials. Blooms from June until snow flies.

Jersey Gem. A short bushy growing variety that blooms throughout the summer. Flowers rich pure violet. large and very fragrant. Has long stems which makes it a splendid cut flower. 3 for 85 cents; 12 for $\$ 2.50$.

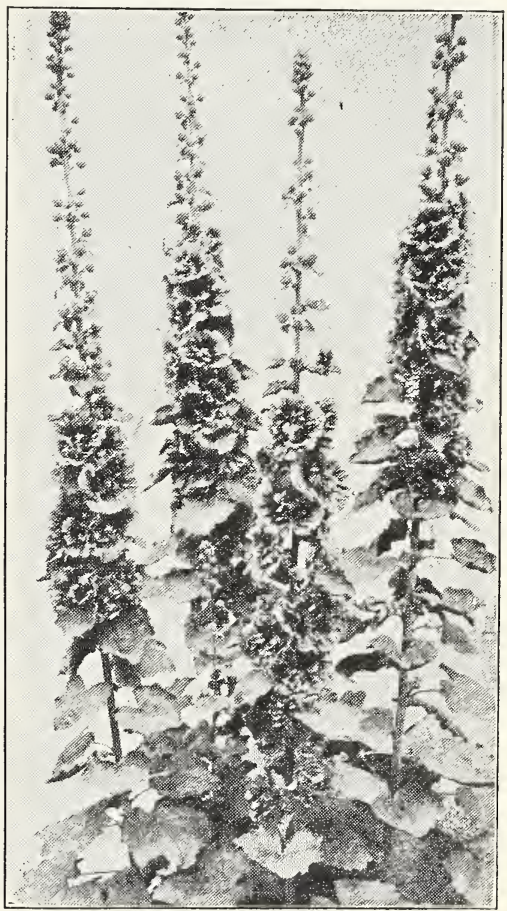

Hollyhocks, Double

\section{Hardy Phlox}

There is no flower that fits into the late color scheme of the garden as well as the perennial phlox. They begin to bloom in the middle of the season and carry loads of the most brilliant color far into the fall or until touched with frost.

They came in many colors from the purest white, through the many shades of pink, lavender, red, purple, to the deepest crimson. For best results the soil should have well rotted manure worked into it and the planting should be in a fairly sunny location, and during dry spells a thorough soaking of water should be given. Once planted they will do well for from four to five years without replanting.

If the first flower spikes are cut off as soon as the flowers fall and the plants are well watered a second setting of bloom will come on and continue late into the fall.

Our collection is made up from the best of the standard sorts to which we are constantly adding the choicest of the new varieties as they come out.

NOTE-When you order phlox from us you get a real Brand Peony Farms plant. Our phlox plants are of the same quality as our Brand Division peony roots. Our plants are selected No. 1 one year field grown plants.

Do not compare our prices for our phlox plants with cheaper prices where orders are filled with plants commonly called Baby Phlox Plants. 


\section{PRICES FOR PHLOX, ALL POSTPAID}

$1 \mathrm{Phlox}$ of any one variety for $\$ .35 \quad 3$ Phlox of any one variety for $\$ 1.00$

6 Phlox of any one variety for $1.75 \quad 12$ Phlox of any one variety for $\mathbf{3 . 0 0}$

We are offering our Phlox in two equally good collections. We have tried to arrange the varieties in each collection so that one is as desirable as the other. Each collection consists of twelve first class sorts made up of all seasons and all colors. We will send either collection postpaid for $\$ 3.25$, or the two to one address for $\$ 6.00$. Or you may make up your own twelve from the entire twenty-four varieties, one of a kind, or as you desire. 12 for $\$ 3.50$, Postpaid.

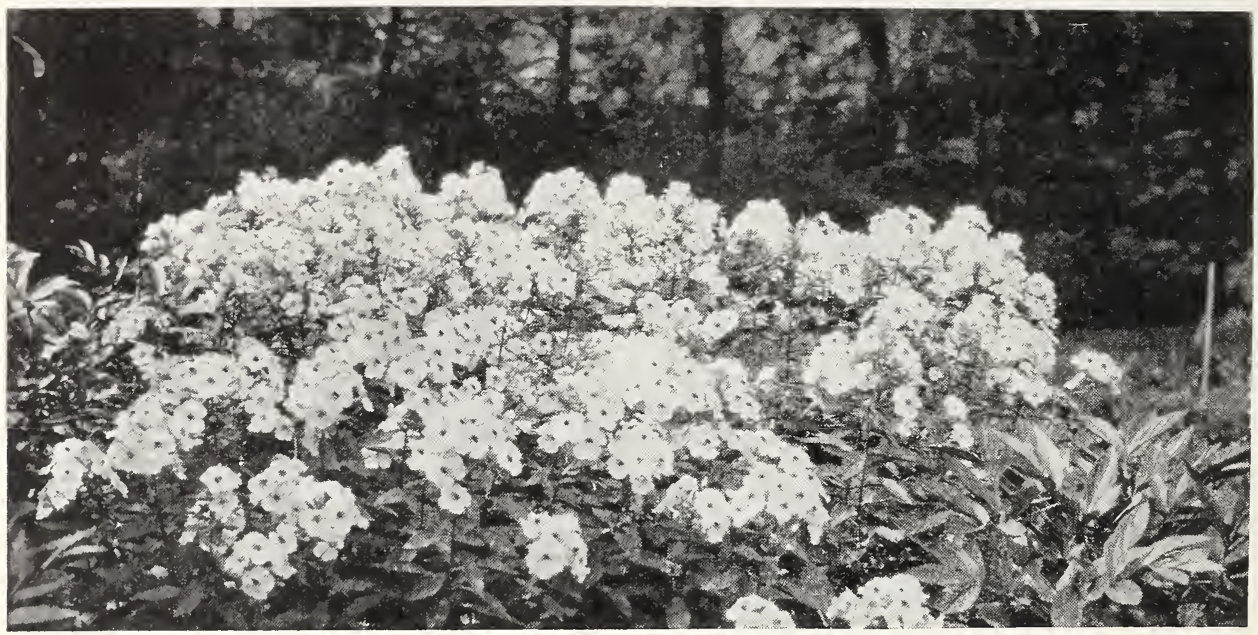

Hardy Phlox, Europe

\section{Collection 1}

Eclaireur. A purplish crimson with white aureole. One of the phlox that seldom kills out.

Europe. A large beautifully formed flower with great white florets with carmine eye.

Elizabeth Campbell. A very large, soft, even, salmon pink with distinct lighter halo. One of the most sought after of all. Frau Von Lassberg. The purest snow white in cultivation large open truss wonderful cut flower.

Grideur. A white with a deep rose center. Petals beautifully flushed with bright rose pink florets large; heavily branched. R. P. Struthers. Rosy carmine with claret eye. Wonderful variety as it stands up so well in hot sun.
Rynstrom. Very large trusses of rosy-pink flowers. Shade of Paul Neyron Rose. Very free flowering.

Siebold. Orange scarlet with red eye. Very thrifty, profuse bloomer. Immense spikes and many of them.

Thor. Great trusses and immense fllorets. Deep salmon pink with aniline red eye. A charming variety.

Von Hochberg. A medium tall growing, very thrifty ${ }^{-}$sort. Deep brilliant red. One of the very best of the red Pholx.

Widar. Very large individual florets of lavender purple with large white center. Large panicles; very attractive.

Wm. Ramsey. A deep reddish purple. The best phlox of its color.

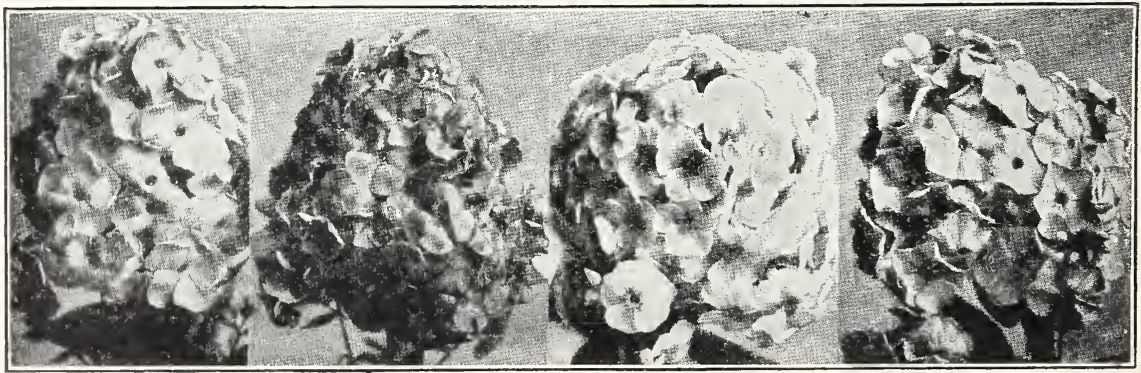

Siebold

B Comple

Thor

Von Hochberg

\section{Collection 2}

B. Compte. A brilliant rich satiny red. One of the most striking of all phlox.

Baron Von Dedem. Bright orange-scarlet with trusses and individual flowers of immense size.

Beacon. A fine brilliant bright cherry red. Trusses of most beautiful form.

Frau Anton Buchner. A pure white that looks very rich. A strong plant that produces flowers of great size and perfect form.

Independence. A white with compact panicles; tall; good to use in outer border.

Jules Sandeau. A very large flowering pure pink. One of the finest.
Milly Von Hoboken. A pure soft pink self color. Grows tall, thrifty and branching. Large well shaped flowers. A splendid new one.

Pantheon. A clear deep carmine-pink with a faint halo. One of the varieties that can be depended on.

Riverton Jewell. A beautiful mauve-rose, made very striking by a large brilliant carmine-red eye.

Special French. A wonderful blush pink with a salmon eye. A profuse blooming attractive new phlox with immense trusses. Sunset. A distinct phlox among the new ones. A beautiful shade of salmon-red.

W. C. Egan. A most delicate lilac-pink with a distinct solferino red eye. Very dainty. 


\section{Delphinium}

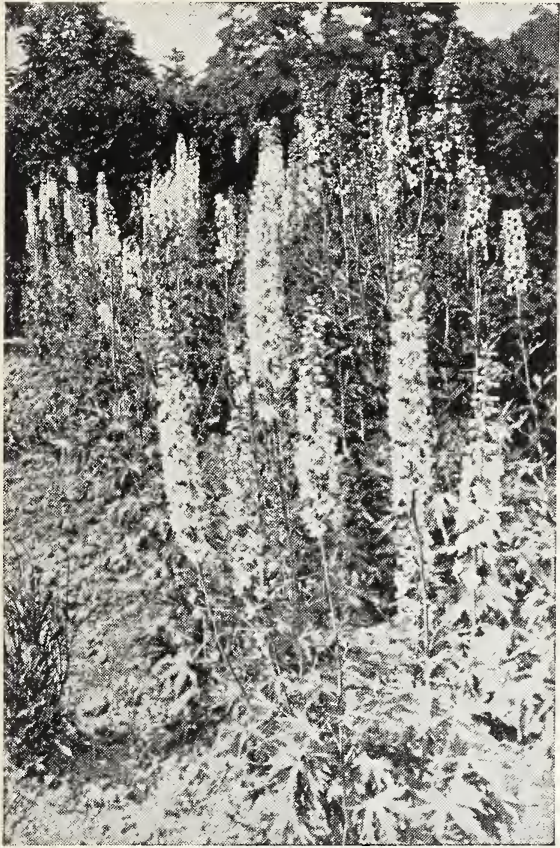

Delphinium, Perennial Larkspur
The Delphinium or Perennial Larkspur is one of the in dispensable flowers to our flower garden. No garden is quite finished without it as it works nicely into so many places. It starts blooming in June and continues throughout the season until frost, if, as soon as the first bloom falls, the old spike is cut off and the root well watered. New shoots will soon appear and the second crop of bloom will soon follow. The Delphinium should be planted in full sun in mellow soil, enriched with well rotted manure. Water as soon as planted.

Last season we offered five different strains of Improved Delphinium but our sales were so great that we almost depleted our entire stock of yearlings and young plants. The result is that this year we do not have any one of these strains in sufficient quantity to dare catalog them separately so we have decided to take what little we have left in all the strains and combine them into one lot, which we will offer in strong two year field grown plants. In the meantime we will have coming on in our fields for this fall's and next spring's sales as fine a collection of Delphinium as is to be found in America, in three distinct strains: Wrexham Hollyhock. Vanderbilt, and Blackmore and Langdon.

This summer these will all bloom out in the open field and all the choice and the extra choice will be marked. We will go through our fields personally and do this checking and will offer these plants for this fall or spring of 1931 shipment as desired at the following prices: Choice, any strain, \$1.00 each; 12 for $\$ 10.00$. Extra choice, any strain, $\$ 2.00$ each 12 for $\$ 20.00$.

Orders should be placed now for this selected stock as it will be all taken up long before fall. Payment, 25 percent down, balance when ordered to ship.

Large two year old plants this spring all of which will bloom this season. Our combination strain, 6 for $\$ 3.00 ; 12$ for $\$ 5.00$.

\section{Gladioli}

\section{The finest of all flowers for cutting}

The gladiolus is one of the easiest flowers to grow and at the same time one of the most beautiful of all flowers. We grow several acres and are keeping pretty well in touch with the new things as they come out that we may add to our offering from year to year the most desirable of these newer kinds. The Gladiolus makes a most beautiful cut flower and should be cut just as the first floret is about half open. Placed in water immediately after being cut the spike will last many days and every bud will open up.

The bulbs should be planted in mellow well drained soil that is free from manure. Large size bulbs, four to six inches deep medium size 2 inches, and small bulbs one inch deep. Plant from April 15 to June 15 in latitude of southern Minnesota.

We are offering our Gladiolus bulbs this spring in three different sizes, large, medium, and small. They are all No. 1 in the grade offered and all sizes will bloom this year. All bulbs are new bulbs grown on from either small bulbs or bulblets this last season.

Alice Tiplady (Primulinus). An orange-salmon; flowers unusually large for this class, and beautifully ruffled. A color everybody likes.

Anna Eberius. Deep Rhodamine-purple. Entirely self color except for deep amaranth purple blotch on lower petals. A great deep purple cut flower.

Baron Hulot. A rich, deep, indigo blue. An old variety but still the best of its color.

Bengal Tiger. A striking variety as it is so different. An attractive combination of gold striped with broad bands of brown.

Break O'Day. Very early. Massive spikes with several open at once. A soft LaFrance pink flushed over a cream ground and shading deeper at edge of petals. The finest extra early gladiolus. Of all our varieties we thought this one of the most beautiful this last year.

Captain Boynton. One of the very finest of all lavender gladiolus. Great strong straight spikes with many large flowers open at once. The best lavender.
Carmen Sylvia (Prestgard). One of the very best of the whites. Pure white with slight violet markings deep in throat. Many open at once.

Crimson Glow (Betcher). Deep scarlet red. A touch of primrose yellow in the throat, overlaid with a deeper red blotch. Very large and thrifty. One of the best dark reds.

Dr. F. E. Bennett (Diener). Peach red, overlaid with flamescarlet. Throat speckled wiih ruby and white. One of the most popular of the new glads and the finest scarlet red in our fields this last year.

Dr. W. Van Flect. A beautiful shade of delicate rose pink, becoming deeper at the edges, with a soft creamy yellow throat. A very delicately formed flower of much refinement.

Dorothy Wheeler. One of the earliest to bloom. A primulinus of a delicate rose pink. Very profuse bloomer. Wonderful for an early commercial cut flower sort.

E. J. Shaylor. A deep rose pink. Throat of lower petals delicately penciled with rose-red. Has received several certificates of merit. Edge of petals beautifully ruffled. One of the best varieties yet produced. Much in demand as a cut flower.

Elf. Opens from a lemon yellow bud to a pure white flower with delicate lemon yellow tip. Flowers are large and spikes perfect. Very small bulbs will produce large blooms. A great cut flower sort.

Elizabeth Tabor. Delicate rosy pink on a white ground, with a large dark crimson blotch terminating in a diamond of soft yellow on the lower petals. Flower spike very long with severa large flowers open at once.

Evelyn Kirtland. Tall growing. Rosy pink, darker at the edges dimming to shell pink at the center. Brilliant scarlet blotches on the lower petals. Very tall spike. One of the very best in its color. 


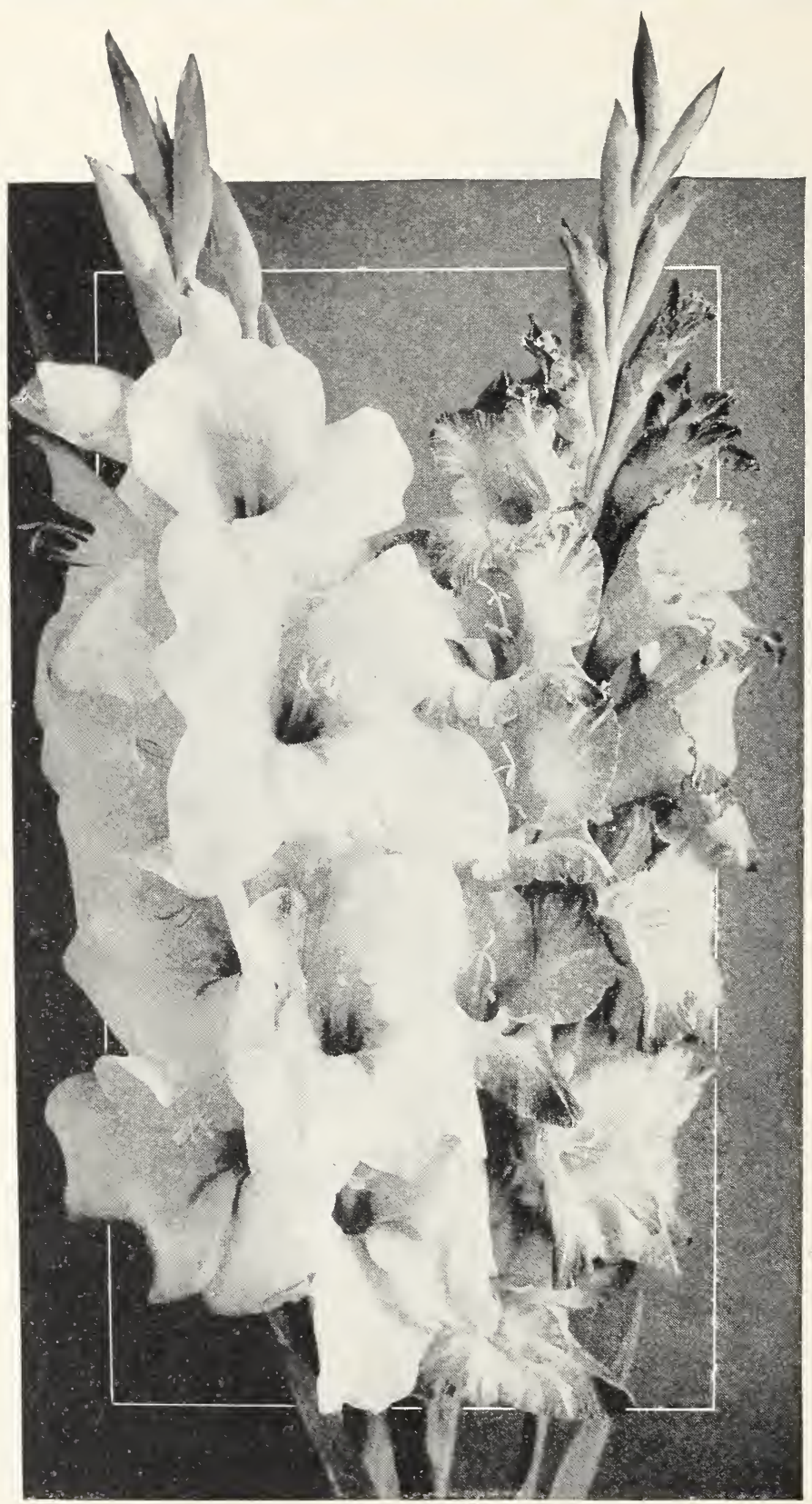

Fern Kyle (Kunderd). A large ruffled flower, creamy white in color. Introduced at $\mathbf{\$ 2 5 . 0 0}$ per bulb. Creates a sensation wherever shown. Awarded first prize as best cream colored variety at American Gladiolus Show, August, 1925.

Giant Nymph. An immense spike with flowers nicely arranged. Very large, wide open flowers. One of the greatest show flowers. LaFrance pink, with creamy yellow throat.

Glendale (W. B. Davis). A rich se!f color a trifle darker than the American Beauty Rose. An unusually good cut flower as it has great keeping qualities.

Golden Dream (Groff). A well formed flower. Many open at once on a long, straight spike. A clear deep yellow. Golden Dream is far and away the best yellow that we have seen.

Golden Measure. Very tall, strong stem. A pure yellow with flowers of immense size. A splended variety.

Halley. Chiefly grown because of its extreme earliness, which makes it very valuable as a cut flower. Large beautiful salmon pink with creamy white blotch in the throat.

Jack London. A light salmon with vermilion stripes, and a canary yellow throat with ruby stripes. A very profitable cut flower.

Jenny Lind. A shrimp pink, deepening to geranium pink at edge of petals. Flowers tubular, ruffled, and edges rolled back. A very beautiful variety.

Le Marechal Foch. One of the earliest. A beautiful sof t flesh pink tinged with lavender. The flower is twice the size of America, which otherwise it much resembles.

Longfellow (Prestagard). This is one of the greatest pink gladioli ever sent out. Stems strong and straight. Flowers a clear LaFrance pink. Are wide open, of fine form, perfectly arranged on the spike. Often eight are open at once. Wonderful. 
Los Angeles. A beautiful shrimp pink with an intense glowing blotch of orange-carmine in the throat. A tall graceful variety that is very lovely in the garden as it blooms over a long period of time anrl often throws a second spike after the first one has been cut.

Maiden's Blush (Gruellman's). Flesh pink, delicately flaked with pale old rose throat suffused with mallow pink. Very dainty and decorative flower.

Mary Pickford (Kunderd). A most beautiful flower. Color a delicate creamy white. Throat soft sulphur yellow with stem and calyx white. We think this one of the finest.

Ming Toy (Primulinus). A large beautifully formed flower, nicely placed on the spike of a very pleasing shade of buffyellow. To our taste one of the best of the Prims.

Mrs. Dr. Norton (Kunderd). Very delicate pink shading to a deeper pink, daintily flaked with a still different pink. Throat light yellow striped with tyrian-rose. One of the finest of all.

Mrs. F. C. Peters (Fisher). A beautiful amaranth pink with large purplish blotch in the throat. A most popular gladiolus sometimes described as orchid colored.

Mrs. Francis King. A large bright pure scarlet flower with long straight spikes. Flowers well arranged and of splendid substance. A grand commercial cutting sort.

Mrs. Frank Pendleton (Kunderd). A beautiful salmon-pink with a large rich deep maroon blotch on the three lower petals. A great favorite.

Mrs. H. E. Bothin (Diener). Delicate geranium pink, heavily ruffed with a flame-scarlet throat. Personally we consider this one of the prettiest of all Gladiolus.

Mrs. J. K. Armsby (Diener). Coral pink with delicate touches of bright red near the edges. Cream throat, dotted with ruby. Very large and many open at once.

Mrs. Leon Douglas (Diener). Begonia-rose striped with brilliant scarlet. The size of the flowers is immense. The stems are very strong and carry many open flowers at once. Mrs. Leon Douglas is one of the greatest show flowers of all Gladiolus. At the different Gladiolus shows all over the country it is always among the winners of the highest awards.

Muriel (Pfitzer). A true lilac, a trifle darker on edge of petals. Petunia violet blotch on lower petals. One of the most beautiful of Gladiolus. Good long spikes with many perfect blooms out at once.

1910 Rose. A rose-pink shading to a pure rose-red. A fine, very early flower that is in great demand as a cut flower.

Prince of Wales (Kelway). Large, clear salmon-pink with deeper markings in the throat. Very early. Very much admired.

Purple Glory (Kunderd). Very large, ruffled flower carried on a massive spike. A tall striking variety, deepest velvety maroon red with darker blotches. A wonderful sort.

Pink Wonder (Kemp). An immense flower, ground color white with beautiful stippled pink edge. A very showy flower.

Richard Diener (Diener). Another flower of which we must say "One of the finest of all Gladiolus." A great, ruffled pale the stem and many open at once. Magnificent.

Rose Ash. Soft, old-rose tones, fading to ashes of roses on the outer edge of petals. This flower has taken people by storm and is in great demand as a cut flower.

Salmon Beauty (Kunderd). A beautiful Prim, with an erect stem with very large flowers. Deep slamon with a rich salmonyellow throat.

Scarlet Princeps (Kunderd). A beautiful soft raspberry red, hading to begonia rose in center. Many large lovely wide open flowers on graceful spike.

Scarlet Wonder. One of the most beautiful scarlet reds yet introduced. Grows four to five feet high, with broad dark green foliage, and a compact spike of great rich velvety scarlet flowers.

Sheila (Coleman). A very pretty flower, exceedingly striking in color. A coral-red flesh pink throat. Primrose blotch on lower petals. In great demand as cut flower.

Sidney Plummer (Salbach). Beautiful soft yellow, suffused delicate pink. Rich amber lip, amaranth purple tongue. Flowers large, nicely placed, slightly ruffled.

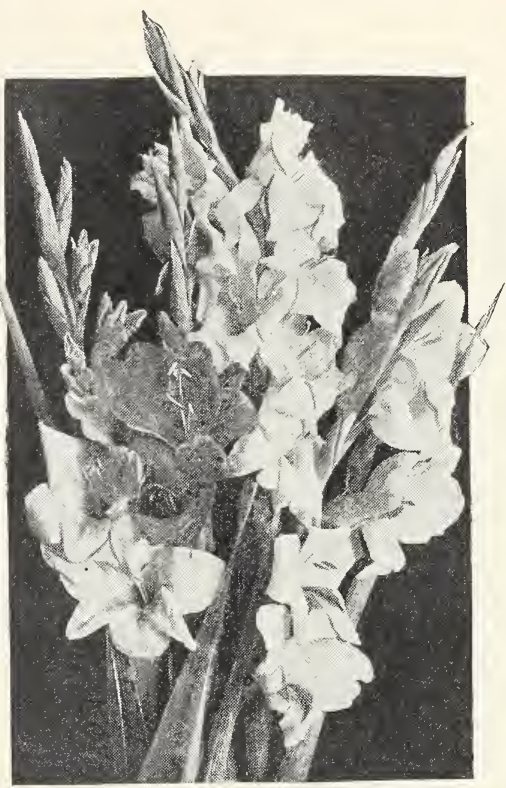

Gladioli

Souvenir (Gravereau). A pure intense golden yellow Primulinus. The best of all yellow Primulinus. Received First Class Certificate, Haarlam Holland 1921. Extra fine.

Tycko Zang (Austin). Immense flower, clear salmon-pink, white throat faintly dotted with deep cerise. Blooms perfectly placed on a straight spike. A wonderfu! new variety.

W. H. Phipps (Diener). A great La France pink, overlaid with light rose salmon, shading lighter towards the center. Flowers of the largest size and of ten tweive perfect blooms are out at once with the bottom bloom in as perfect condition as the top one. The finest of all pink Gladiolus.

Wilbrink (Hopman), One of the earliest. A pale pink with upper petals tinted slightly darker. Lower petals blotched purple on yellowish ground. Strong thrifty variety much used as a cut flower.

White Butterfly (Kunderd). A first class primulinus, all white with cream white throat. Won many prizes at the American Gladiolus Show, 1925, both in combination with other primulinus varieties and also as the best white Primulinus Hybrid shown. In 1926 White Butterfly was again awarded first prize as best white Primulinus.

\section{Rainbow Mixture}

We are offering this season to our customers who do not care to buy named labeled varieties a very fine mixture which we call our Rainbow Mixture. Every order that goes out of this mixture is made up entirely of selected named varieties, as we do not keep in our fields any unnamed sorts. This mixture will be made up of only No 1 sorts in all the different color and will be sold much cheaper than we could sell the same bulbs if we had to go to the trouble of naming them. Each mixture is liable to have a few bulbs in it which if bought alone would be worth the price of the entire mixture. We offer this mixture in the three different sizes of bulbs: Large size, 100 for $\$ 6.50$ 50 for $\$ 3.50 ; 25$ for $\$ 1.75 ; 12$ for $\$ 1.00$. Medium size 100 for $\$ 3.50 ; 50$ for $\$ 1.75 ; 25$ for 90 cents; 12 for 50 cents. Small size, 100 for $\$ 1.50$. All Prepaid.

100 Gladiolus for $\$ 1.50$. Just imagine what joy one can get out of $\$ 1.50$ invested in 100 Gladiolus bulbs all of which should bloom the first year. A collection of many different colors of all named kinds but not labeled. Be sure to include one of these $\$ 1.50$ collections in your order. 
Prices of Gladioli

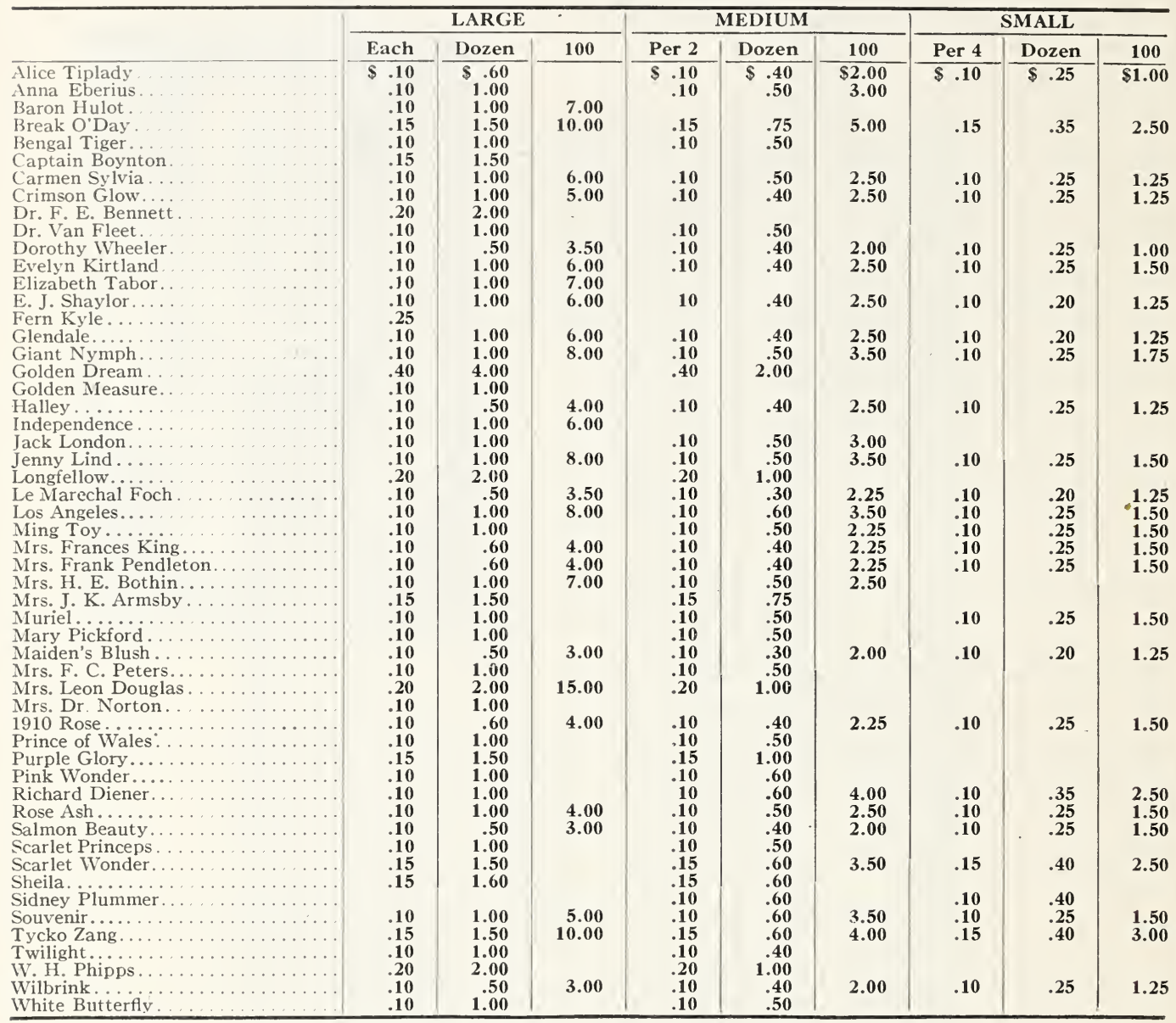

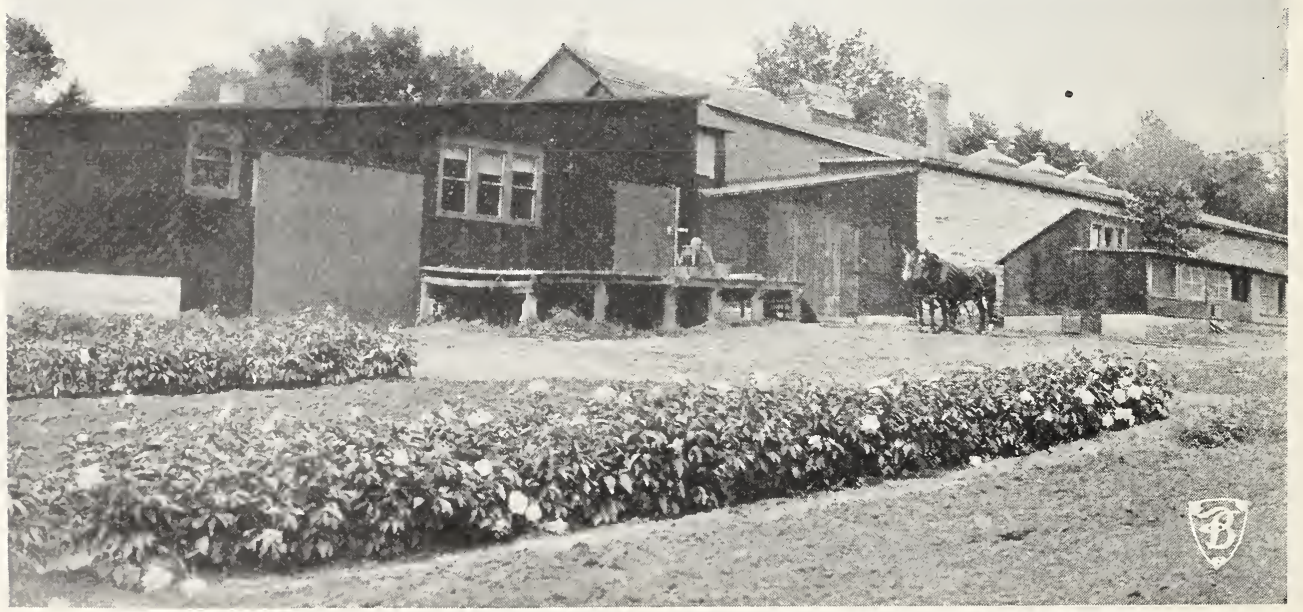




\section{Roses}

We send out a good many thousand Rose Bushes every spring and our business in this line is rapidly increasing.

We have our roses grown for us by the best rose growers of America and we feel safe in saying that our rose bushes are as fine as can be bought anywhere in the land. So we ask you to bear this in mind in comparing our prices with roses offered cheaper, that you are buying as good rose bushes as you can buy anywhere in America. Last season we had many people write us complimenting us upon what nice roses we had sent them and as to how nicely they were doing.

Roses should be planted where they are somewhat sheltered by buildings, hedges, plantings of shrubbery from the full force of the wind.

The rose likes a rich mellow soil into which has been worked rotted leaf mold, rotted sod, and well rotted cow manure. Plant the bushes with the top of the roots about two inches below the surface. Trim the branches back to around eight inches. In the fall mound the dirt up into the branches in pyramidal form about a foot and after the soil freezes hard scatter a coarse mulch in between the branches and over this mound about two inches thick.

\section{Hybrid Perpetual Roses}

Frau Karl Druschki. A very vigorous growing variety producing very large, pure white blooms. Regarded as the best Hybrid Perpetual white.

General Jacqueminot. A rich, deep crimson rose of delightful fragrance. Produces a profusion of bloom in early summer. One of the favorite roses.

Mrs. John Laing. Plants grow erect with beautiful soft pink cup shaped flowers. A most fragrant sort and a continuous bloomer.

Paul Neyron. Another of the old time universally favorite roses. Very large, prof use, rich rose pink. Does well everywhere.

Persian Yellow. An Austrian Briar Rose producing small semi-double, deep yellow flowers along the branches in late spring. One of the old favorites.

Prince Camille De Rohan. Flowers are a very dark red, almost a maroon. Blooms of medium size, very double and sweet scented. Everyone likes it. Price of strong, two year No. 1 plants of the above roses, 80 cents each; 6 for $\$ 4.50$, Postpaid.

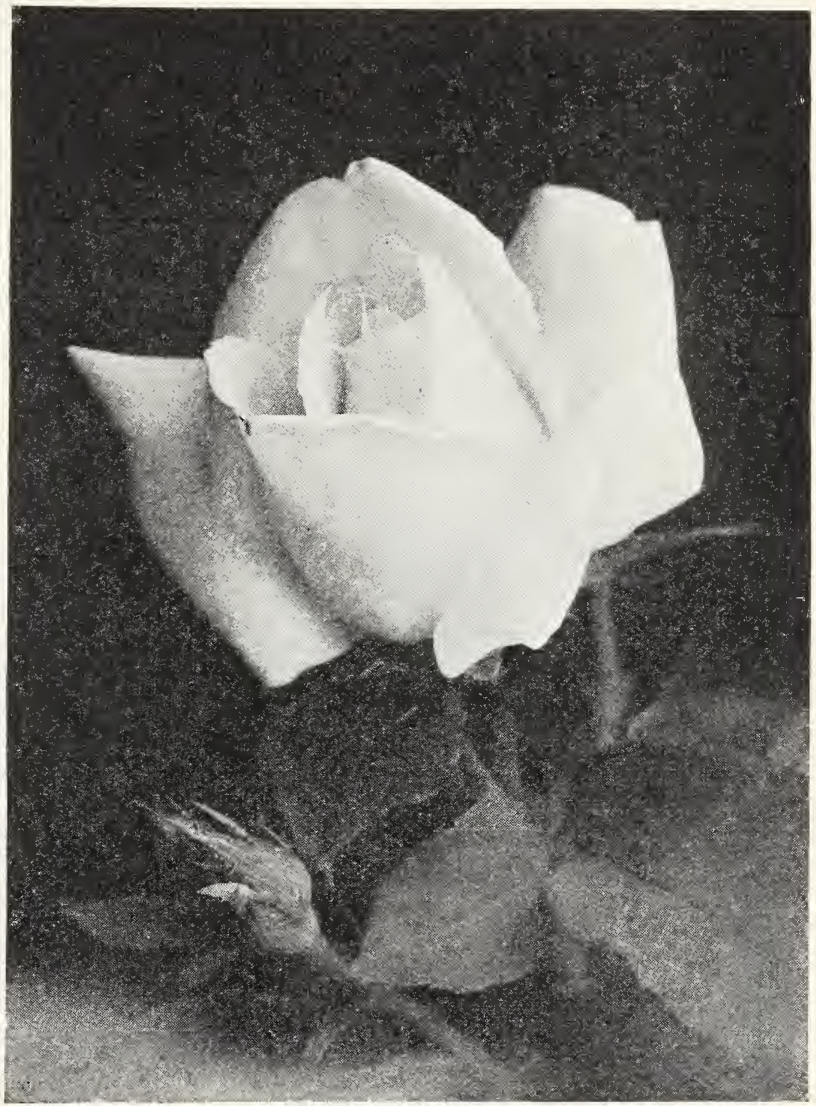

Frau Karl Druschki

\section{Hybrid Rugosa Roses}

Rugosa and Hybrid Rugosa Roses are very desirable where extremely hardy roses are demanded. These roses are also in great demand because of the luster and beauty of their foliage, working exceedingly well into hedge and mass plantings. Varieties listed are doubies.

Chas. F. Worth. A splendid free blooming crimson. Large flowers in great profusion.

Blanche De Coupert. The best double white among the Rugosas. Free flowering. A most beautiful rose.

F. J. Grootendorst. Flowers which are of an intense bright red come in-clusters like those of the Crimson Rambler but they resemble the hardy red carnation. In continuous bloom all summer. So far the very best rose for the far north.

Hansa. Probably the best known of all the Rugosas. A very large semi-double flower, reddish violet in color. Very satisfactory.

Mrs. Anthony Waterer. A bright red Rugosa that is very desirable. Flowers are very large and of perfect form. A splendid sort.

New Century. A beautiful flesh pink that works in very nicely with the other Rugosas listed.

Sarah Van Fleet. A new Hybrid Rugosa that is a real ad- dition to that type of roses. Full double. A perpetual bloomer. A beautiful wild ro 3 p pink. Price of above seven Hybrid Rugosa Roses all in ctrong field grown two year No. plants, 75 cents each; one each of the seven kinds, $\$ 4.90$, Postpaid.

Rugosa Rubra. The single pinkish red Rugosa that is used so much for landscaping and hedging Very hardy, rich glossy leaves, large pinkish red blooms followed by large bright red leaves, large pinkish red blooms followed by large bright red
fruits which stay on way into the winter. 35 cents each; 10 for $\$ 3.00 ; 100$ for $\$ 20.00$.

Siberian Rosa Rugosa. The Siberian type of the Rosa Rugosa. The Rosa Rugosa as we commonly have is the Japanese type and is not so hardy a bush as is the Siberian type. This Rugosa was brought over from Siberia by Professor Hansen on one of his trips to that cold bleak country. This Rugosa is native there and perfectly hardy. Finer and more krinkled foliage than the Japanese type. Beautiful large double wild rose pink flower. A beautiful new rose for the border. 2 to 3 feet, $\$ 1.00$ each. 


\section{Hugonis Rose}

In the Hugonis Rose we have one of the finest floral introductions of recent times. This rose comes to us from China and is perfectly hardy, growing on our grounds in the most exposed places without any winter protection. The bush throws up many branches to a height of six to eight feet, sending slender sprays in all directions which arch gracefully beneath great loads of bright yellow single flowers of the most exquisite beauty. Very strong plants by mail, 85 cents each; 10 for $\$ 8.00$; by express collect, 10 for $\$ 7.00$.

\section{BABY RAMBLERS}

Crimson Baby Rambler. This is the original Baby Rambler. A beautiful crimson red. Make wonderful pot plants for winter decoration. In the summer are beautiful to plant in rows along the borders. In bloom continuously all summer. By mail, 75 cents each; 10 for $\$ 7.00$, Postpaid. By express collect, 10 for $\$ 6.25 ; 100$ for $\$ 50.00$.

\section{SPRAY FOR ROSES}

Derrisol. Roses are apt to be troubled with aphids, thrips, and leaf hoppers. For these troubles we find Derrisol the very best of sprays and very satisfactory. $1 \mathrm{oz}$. bottle makes 6 gals. Spray 30 cents. 8 oz. bottle makes 50 gals. Spray $\$ 1.25$.

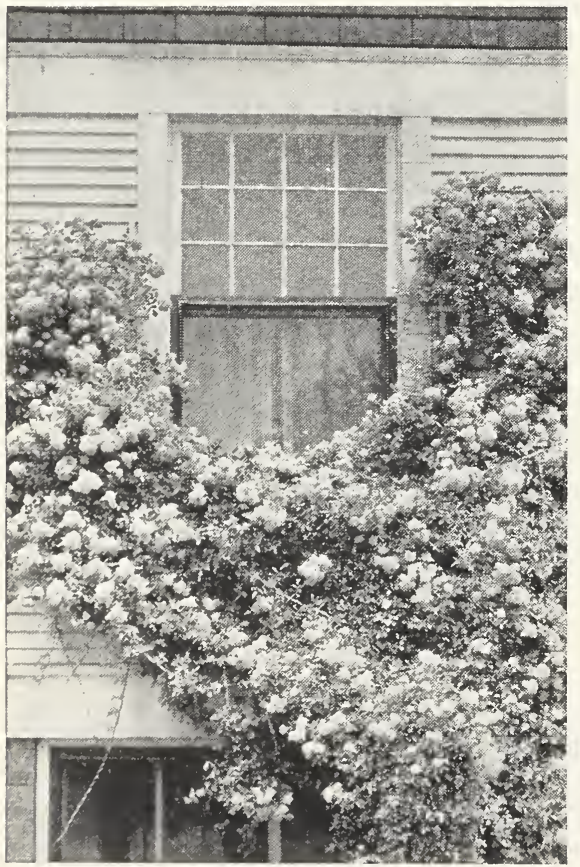

Excelsa Rambler

\section{Garden Roots}

Mary Washington Asparagus. This is the newest and best asparagus brought out and introduced by the U.S. Department of Agriculture. It is the most rust resisting of all asparagus, is the earliest to come on, and the largest of all in size.

Giant Victoria (Rhubarb or Pieplant). Large, early, tender, red stalks. The best and sweetest of all rhubarbs.

Malner Horseradish. A splendid horseradish introduced by the U. S. Department of Agriculture. Produces a wonderful large, white root, much nicer than the old sort.

\section{PRICES}

\begin{tabular}{|c|c|c|c|c|}
\hline Per 6 & 25 & 50 & 100 & 1000 \\
\hline 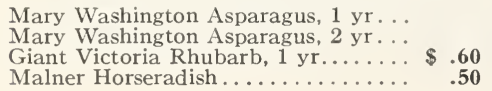 & $\begin{array}{r}\$ .50 \\
.90 \\
3.00 \\
2.25\end{array}$ & $\begin{array}{r}\$ .90 \\
1.50\end{array}$ & $\begin{array}{r}\$ 1.60 \\
2.50\end{array}$ & $\begin{array}{r}\$ 8.00 \\
16.00\end{array}$ \\
\hline
\end{tabular}

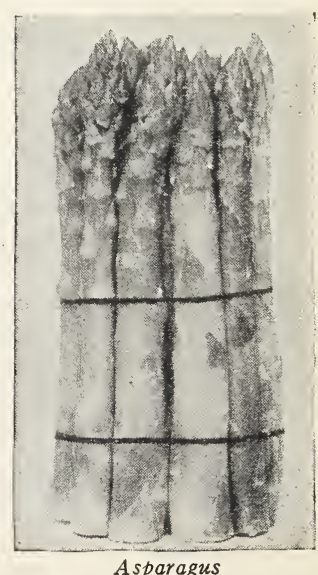




\section{Fruit Department}

\section{Brand's Imperial}

Oliver F. Brand, during the many years he was actively engaged in the nursery business here in Faribault, was constantly endeavoring to produce something new in apples that would be of value to the middle Northwest where hardiness was the first requisite in an apple tree. He had seen all of the gond old standard sorts brought in from the eastern states tried out and had seen them all pass out because of tenderness and their inability to withstand our winter climate. He early realized that if the people of Minnesota were to grow their own apples, there must be produced a line of varieties hardy enough for the peculiarities of this climate. And to do his part in bringing this about, during all the years he was engaged in the nursery business here, some 43 years in all, he planted a few carefully selected apple seeds each year. And out of all the resulting apple seedlings he tested out, several very fine apples were produced. bearer

His first seedling of value was the Estaline, a large crab or hybrid, that has proven extremely hardy and a most wonderful

While the Estaline was still a young tree, and before it had started to bear, Mr. Brand discovered in his Duchess of Oldenburg orchard a tree that to all intents and purposes was a Duchess except that the apples were mostly all red. The "Red Duchess."

Then came the Judge Berry, A hardy tree, an immense apple that ripens soon after the Duchess of Oldenburg and an apple of superb eating qualities.

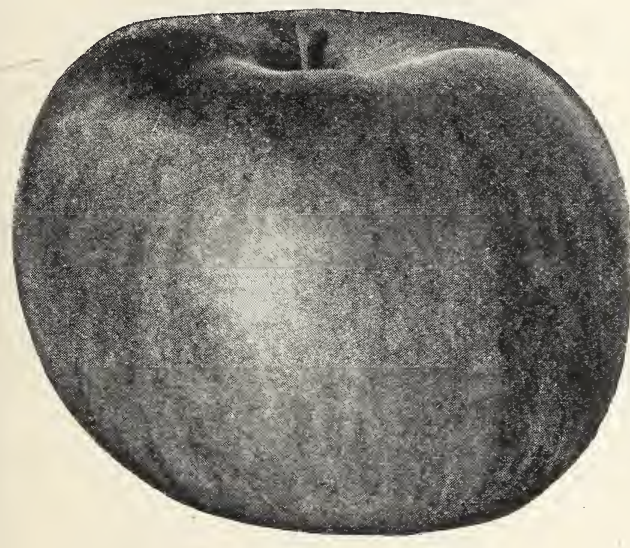

Brand's Imperial
Then just about as Mr. Brand was retiring from the business one of his last lots of seedlings came into bearing. One of the trees came into bearing very young and produced quantities of large uniform shaped beautiful apples of an all over deep bright red. The apples were so large, so shapely, and of such a pleasing color that everyone noticed them. As they ripened it was found that they were a fall apple with keeping qualities somewhat like the Wealthy, that the flesh was a pure white and the flavor very fine. Root grafts were made of the variety that fall and planted into the nursery the next spring. Scions were also saved until spring and quite a few trees in the orchard top worked to the seedling. These top worked trees invariably began to bear at two years and bore beautiful apples like those of the mother tree. The root grafts in the nursery came splendidly and produced a uniform lot of mostly first grade trees, with the limbs going out horizontally from the trunk of the tree and producing heavy strong shoulders like those of the Hibernal enabling the tree to carry without the limbs splitting down the immense crops of apples which it produces. As a nursery tree it has proven the finest and hardiest tree we grow. It has shown so many good qualities that we named it Brand's Imperial.

Grows into a large spreading tree that bears great crops of beautifully formed apples of a deep red. Splendid quality. One of the hardiest of all apple trees.

We have a large stock of Brand's Imperial trees which we are offering at the following very reasonable prices: Nice 4 to 5 foot trees, 60 cents each; 10 for $\$ 5.00 ; 100$ for $\$ 45.00$. Nice 5 to 6 foot trees, 75 cents each; 10 for $\$ 6.50 ; 100$ for $\$ 60.00$.

\section{Apple Trees}

In apple trees, as in everything else, our customers can depend on getting strictly first class trees and trees true to name.

The varieties listed are all standard sorts selected with the utmost care for critical customers. Varieties where the name is followed by xxx are extra hardy and recommended for planting in Minnesota and similar climates.

\section{Brand's Red Duchess}

Brand's Red Duchess xxx. In the summer of 1886 we had in our nursery here a small orchard of Duchess of Oldenburg, off by itself, surrounded by open field. There were probably sixty of the trees all told, in three parallel rows. That year these trees, then about twelve years old, bore heavily. When the fruit ripened and we came to gather it we-noticed that the apples of one of the trees differed from those of the rest. This tree, to all intents and purposes, was a Duchess. The tree looked like a Duchess, the fruit ripened at the same time as the Duchess, but it differed from the fruit of the other trees in color, which was a deep, almost solid red. We watched this tree for several years and it always came the same. The balance of the trees were regular Duchess with the fruit oblate, yellowish green with red stripes. The fruit of this tree was always red. This tree could not be distinguished from the other trees in any way, but in its always bearing deep red apples. Then we began to propagate this tree and before sending it out, brought the young trees into bearing in our own orchard. They came true to their mother tree; they too, bore all red apples.

After thoroughly testing it out and finding that the young trees always bore red apples, we named it Red Duchess, and sold it all over the state. There are now many of these trees in full bearing and they all bear red apples. In fact it is a sport from the Duchess or a red apple the result of a bud variation. The Duchess of Oldenburg is the most profitable of all early commercial apples. The Red Duchess, because of its all red color, will make a much more profitable tree to plant than the regular Duchess. Nice 5 to 6 foot trees, $\$ 1.00$ each; 10 for $\$ 9.00$. 


\section{The Haralson Apple}

Ever since the first lover of a good apple came into Uinnesota, to make that state his home, there has been an increasing search for a good real winter apple that was hardy enough to stand the peculiar conditions of our winter climate. It seems that at last this much-sought-for apple has been found. Among the many different fruits that the Minnesota State Fruit Breeding Farm has been experimenting with, the apple and the plum have probably received the most attention. I had the pleasure of visiting the station this summer just at the time when the plums were at their best and when the apples, although not yet ripe, were all colored up and showing to wonderful advantage. I saw many trees of Folwell. Ninnehaha and Wedge, three of the station's best new varieties, just literally loaded with their immense crops of large, fine shaped, well colored apples. But of all the apples I saw in the station orchards on this trip, I was most impressed with the variety named Haralson. The trees of this variety were younger than those of the other sorts and because of this, not so large, but every tree was loaded with every apple it could well carry. And such apples. Great big, red fellows that just made one's mouth water to look at them. I had heard of the Haralson for several years and had noticed it at the winter meetings and was very much impressed with its appearance and keeping qualities, so much so that I was keeping very close track of the apple and when I received word from Secretary McIntosh, of the State Horticultural Society, last March. that they had some specimens in the cellar and that if would come up we would sample them, I jumped at the suggestion, and the next day found me at the University Farm. In company with Secretary McIntosh, I was piloted by Mr. Fred Haralson, now in charge of the Breeding Farm, to the basement of the Horticultural Building of the Uni-

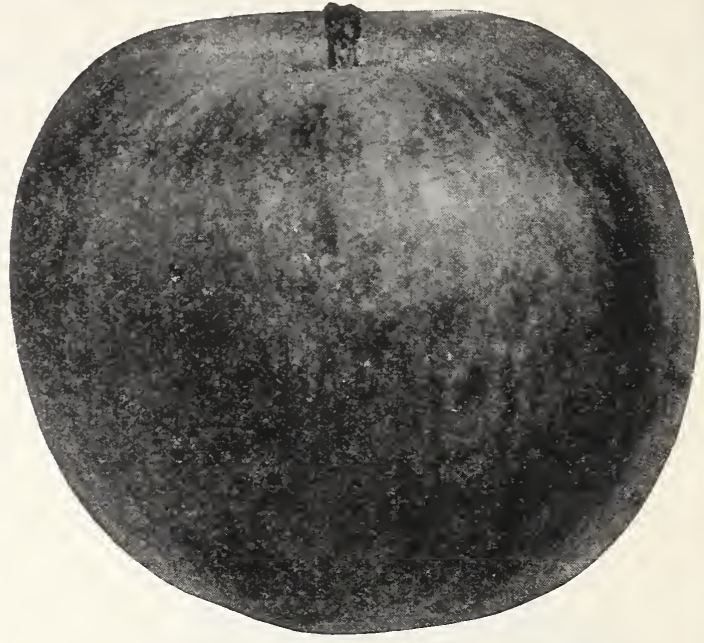

The Haralson Apple

versity Farm, and here we found several very promising new apples at that late date, March 8 th, still in splendid condition. None of these apples had been in storage. They simply lay in apple boxes in a cool cellar, the temperature of which was regulated as best it could be by the opening and shutting of a single side window. Of all the apples tasted, the Haralson was far and away the best. Truly an apple of outstanding merit. The apples were very large in size, averaging about four inches in diameter rather flat, and of a beautiful red color. When cut, the flesh was white, firm and crisp as would be a Wealthy a few days after being taken from the tree in the early fall. And the flavor was splendid. I believe we have in this apple all that can be desired in a winter apple. I have never seen or tasted a better one. It is a true winter apple. An apple that will rank as to quality and appearance right up with such apples as the Jonathan, Spitzenberg and the Delicious. Notwithstanding the fact that the trees which I saw at the Fruit Farm had been heavily cut for propagating wood during previous years, they were carrying a great crop of fruit and I felt that we were very fortunate to be in possession of a small stock of this wonderful variety to offer our customers.

We wrote the foregoing about the Haralson in the spring of 1924 . We have carefully watched the variety ever since and our good opinion of it has increased every year since.

We planted forty-five little three to four foot, single stemmed, one year old trees, the largest we could then get, in our orchard that spring. Last year these little trees, then five years old, started to bear and this year we had a splendid crop of great big fine red apples on them.

We consider Haralson the finest and best of all the apples brought out by the Breeding Station. Trees absolutely hardy, thrifty growers and young bearers of large red apples of splendid flavor that will keep sound and crisp all winter.

We are offering a fine lot of trees in three sizes:

\begin{tabular}{|c|c|c|c|}
\hline & Each & 10 & 100 \\
\hline Nice 4 to 5 foot trees. & $\$ .50$ & $\$ 4.50$ & $\$ 40.00$ \\
\hline $\begin{array}{l}\text { Nice } 5 \text { to } 6 \text { foot trees. } \\
\text { Nice } 6 \text { to } 7 \text { foot trees. }\end{array}$ & $\begin{array}{r}.75 \\
1.00\end{array}$ & $\begin{array}{l}6.00 \\
8.00\end{array}$ & $\begin{array}{l}50.00 \\
\mathbf{7 5 . 0 0}\end{array}$ \\
\hline
\end{tabular}

These 6 to 7 foot trees are a bearing size tree and many of them would have borne if they had been left undisturbed this year.

\section{McIntosh Apple}

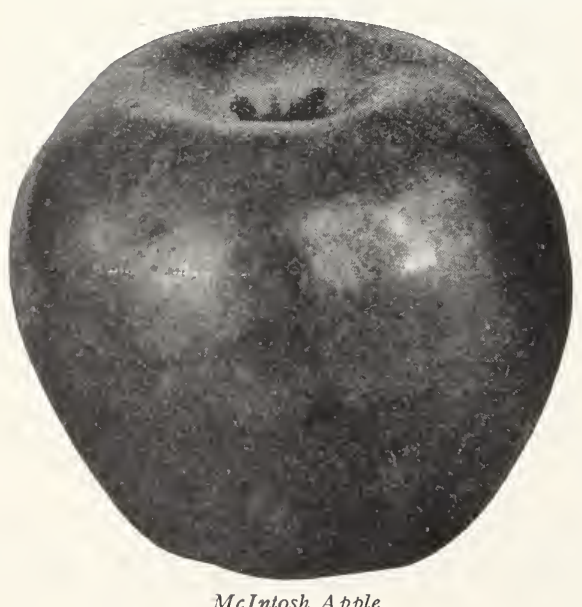

McIntosh Apple

Cortland. A wonderful new variety sent out by the New York State Experimental Station. It is a seedling of McIntosh but is a still better apple. Fruit larger and more uniform in size, very highly colored, very rich in flavor, firm and juicy. Clings to the tree and ripens later than McIntosh thus extending the season. A splendid variety for the commercial orchard. Recommended for southern Minnesota, south and east.

Delicious. A wonderful apple that has become the leading apple of the United States within the last few years. Fruit large, dark red, and of a mild and truly delicious flavor. Fine grained, crisp, juicy, wonderful bearer. Tree hardy and producing annual yields.

Duchess of Oldenberg xxx. Season August. A handsome, large, greenish yellow apple almost covered with stripes and splashes of bright red. Flesh white slightly acid, tender, juicy, and pleasant. A kitchen apple of the highest quality. Absolutely hardy.

Jonathan. A grand, good Winter apple. Bright, solid red. Flesh white, sometimes tinted with red firm, fine, crisp and tender-a splendid family sort and highly profitable for market. Tree long lived, productive, and an early bearer. Will keep well without especial care, and also stand much handling.

Northwestern Greening. December to March. Very hardy, bears young and yields large crops of fine apples. Fruit large, oblong, yellowish green. Firm, juicy, sub-acid, good. A long keeper. A splendid winter apple for the Northwest. 
McIntosh Red. December to March. A large deep crimson apple that is very beautiful. The tree is hardy and vigorous and is found doing splendidly in favored apple locations of Minnesota and Wisconsin. Flesh pure white, crisp, and very tender. Flavor splendid. McIntosh is one of the strictly finest apples that we can grow in Minnesota, and we recommend it highly for favored locations in the southern third of the state and south and east.

Perkins xxx. One of the famous new apples sent out from the Perkins Orchard at Red Wing, Minnesota. Probably the best of all the Perkins' seedlings. A large somewhat conical apple that as it ripens takes on a beautiful all over shade of red. thangs well to the tree. A splendid keeper as it does not mellow up and become eatable until late February. Very hardy and heavy bearer.
Wealthy xxx. October to January. A vigorons spreading grower, immensely productive and very hardy. Fruit above medium to large, oblate, very regular in shape, light yellow, almost wholly covered with bright red. A beautiful fruit. Flesh white, often stained with red, tender very juicy, slightly sub-acid. One of the finest of all apples.

Wedge xxx. One of the best of the new apples sent out by the Minnesota Fruit Farm. Very thrifty heavy bearing tree, tall, spreading upright grower. Fruit large, conical, deep red. A late keeping variety that is of fine flavor when it mellows up in the winter.

Yellow Transparent xxx. Ripens in late July. One of the very best early varieties. The skin is a clear yellowish white. Flesh white, tender, sub-acid. A Russian variety that is very hardy in the far north.

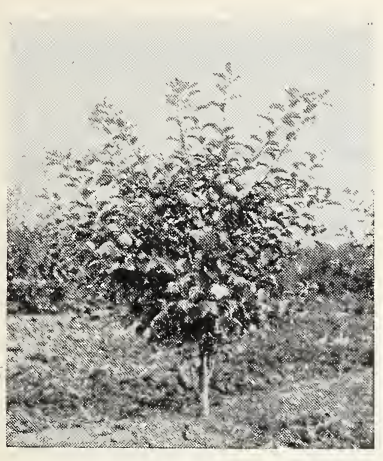

Anoka Apple Tree

\section{Dwarf Apple Trees}

Anoka xxx. This is a natural dwarf apple tree. Most of the Dwarf Apples offered in commerce are produced by grafting or budding the standard apple of the variety desired onto certain kinds of root that act as a check on the growth of the top and dwarf it. This is not desirable. But with the Anoka, it is different. It is a dwarf in itself and produces a dwarf top when propagated on the regular root used in producing the standard apple tree.

Anoka is a new apple produced by that plant wizard of South Dakota, Professor Niels Hansen. The tree bears very young, often producing apples on two year old trees in the nursery row and is a heav y and annual bearer. The fruit has much the appearance of Duchess of Oldenberg but is larger and a little more oblong, and does not show quite so much color. tt ripens very early beginning around August 15. The flavor is mild and very fine. We like it much better than Yellow Transparent.

The Fargo, North Dakota Experimental Station reports on four trees sent it in the spring of 1920 (1 year trees). In the fall of 1922 the following report was made. "This spring two of the four trees blossomed, one produced 23 apples, the other $26 . "$

Two years ago we purchased two trees from Professor Hansen and this last year one of the little trees then only a three year old produced 14 large great apples and the other 12. Neither of the trees are over five feet tall.

In the spring of 1929 we had some sixty little 2 to 3 foot Anoka Trees left over that we did not sell. These were lined back into the nursery and many of them bore, one of them having seven large, well developed apples.

This is just the apple for people getting along in years to plant as they will bear in two years and they are also just the apple to plant in the back yard or in any little nook or corner when room is scarce. Nice 2 to 3 foot trees, 60 cents each, 10 for $\$ 5.00$.

\section{Crab Apples}

Early Strawberry xxx. Season August. Tree large, spreading, very productive. and the earliest of all to ripen. Fruit medium size, greenish yellow with carmine stripes. Flavor mild and pleasant. One of the old time favorites in the northwest.

Transcendant xxx. Grow's to be an immense great tree that often produces twenty bushels of nice large crabs. Bright, dark red, crisp and full of juice. When canned, preserved or pickled, this is the finest of all crabs. Wnen I was a boy Mother used to put Transcendants down in gallon jars and lots of jars at that, and my how good they did taste. I can taste them yet and it is fifty years now. There is nothing better.

Whitney xxx. September. A universal favorite. A young and annual bearer of immense crops of dark red fruit which is conical in shape and sweet. Splendid to eat from the hand and for sweet pickles.

Wherever xxx follows the name of an apple that means that apple is hardy enough to be planted in Minnesota and similar climates.

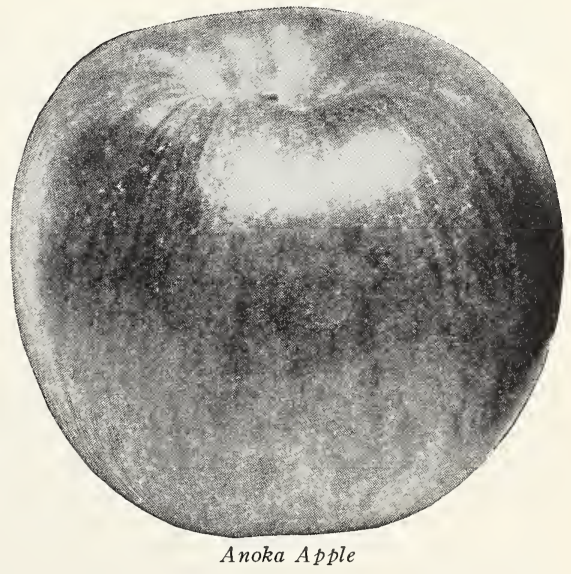

\section{Selected Apple Trees}

We do not sell the grade of apple trees ordinarily sent out by catalog houses, which is, as a rule, quoted as a 4 to 6 foot tree and which in reality is the regular nursery grade known as 4 to 5 foot.

Our trees in Cortland, Delicious, Duchess of Oldenburg, McIntosh Red. Jonathan, Northwestern Greening, Perkins, Wealthy, Wedge, Yellow Transparent, Early Strawberry, Transcendant, Whitney, etc., will all be supplied in a 11-16", 5 to 6 foot tree or what is known as the best grade in the nursery trade. The home garden and the small home orchard wants quick results and so we are sending a big tree. Prices of all the foregoing apple trees: All varieties, 11-16" and up, 5 to 6 feet, 60 cents each; 10 for $\$ 5.50 ; 100$ for $\$ 50.00$. 


\section{Plums}

U NTIL Professor Niels Hansen, of South Dakota, began his work in improving the plum, all that those of us who live in the middle Northwest had in plums were selected varieties of the native wild plum.

It is true that these plums were pretty good in their way especially such varieties as DeSoto, Stoddard, Forest Garden, Terry, and Wolf and we were pretty well satisfied with them until the time came when the west coast began to ship into our markets the large beautiful looking plums which grew in the orchards of Oregon and California. These plums because of being picked before they were ripe, so as to stand the long shipment, were not very well flavored, but their size and looks commanded a market for them notwithstanding and one could not help buying.

But these big nice looking plums gave our fruit breeders an idea. Why could not these wonderful western plums be crossed onto the best of our hardy iron clad plums and give us just as large and nice looking plums and still plums that were hardy enough to stand our climate?

\section{At about this same time the State of Minnesota established the Minnesota Fruit Breeding Farm.}

This farm has since grown into the greatest fruit breeding establishment in the entire world. A splendid article on Fruit Breeding in the Middle Northwest will be found in the issue of Dec.1929 of the Country Gentleman. This article describes in detail the work done along these lines in Iowa by Mr. Patten, in South Dakota by Dr. Hansen and in Minnesota by the State Breeding Farm under the direction first of Mr. Charles Haralson and since his retirement by Professor Alderman.

Hansen, at Brookings, brought out the first lot of Improved Plums and gave us among many good ones, Sapa which we conider, everything considered, his best.

Just as we were getting thoroughly acquainted with the Hansen Plums, Haralson, of the Minnesota Station began to show at the Minnesota State Fair the great line of new plums which he had produced as hybrids between Burbank and other plums from the Coast and the Wolf, a very large free stone native of good quality.

We immediately secured scions of these new Minnesota plums and the next spring top worked them into our plum orchard. From these we have propagated for a good many years. In the meantime, we have been testing the different sorts out in our orchard for the last six or eight years and are offering this year the varieties which we consider the best so far of all the new plums sent out from these two great plum breeders.

\section{Plant A Plum Orchard}

We have picked out and now offer to our customers only those varieties which have proven with us safe plums to plant for commercial orcharding. These big plums are mostly as large as the average run of eggs laid by the White Leghorn hen. They are tremendous bearers, good looking, and easy to pick. The trees should be planted 17 by 18 feet and this takes 140 trees to the acre. These Plums should bear an average of a bushel to the tree when they are set four years (they will bear a good deal more). This makes 140 bushels to the acre. These plums sell right at the orchard at $\$ 3.00$ per bushel. This makes a gross income of $\$ 420$ an acre.

We believe that every village of a thousand inhabitants can support in fine shape one such one-acre orchard, and we believe it safe for some one interested in fruit to plant such an orchard.

After testing out various plums for the last ten years in our own orchard, we have selected the following as the best bearers and choicest plums.

Elliott (Minnesota No. 8). This tree is a strong grower and is very hardy. It ripened a crop of fruit in 1921 up north of Winnipeg. The Elliott is a very productive variety and bears a crop every year. Season about September first. Medium to large in size. Firm, clingstone, pit small, quality good, color yellow overlaid with red. This is a splendid late plum to sell in the home or distant market as it is very firm. We consider Elliott one of the most dependable of all the Minnesota Plums. Late.

Red Wing (Minnesota No. 12). A regular bearer and hardy as far north as the Twin Cities. The fruit is very large, firm, and of the best quality; color yellow overlaid with bright red; stone small and entirely free; very sweet. An exceedingly fine eating plum. Season, third week in August. A good shipping plum and splendid for cooking. Very easy to peel. A wonderful plum.

Sapa. An extremely early, vigorous bearer. Fruit medium size, glossy black; flesh deep reddish purple, excellent flavor, skin very tender. Fine for eating fresh and makes good preserves and jellies. Sapa plums raised at Brookings, S. D., were one and three-eighths inches in diameter and weighed fiveeighths ounce, from one-year trees set out the preceding year. This year we had the greatest crop of Sapa plums that we ever had. We had about one hundred three-year trees bear in the orchard. These little trees were so loaded that their limbs just bent to the ground on all sides. We ate all we could of the fruit, we canned it, preserved it, made jelly of it. Sapa trees should be in every orchard. We had trees of this among our two-yearold nursery stock not more than two feet high that bore as many as thirty-six great dark purple plums to the tree.

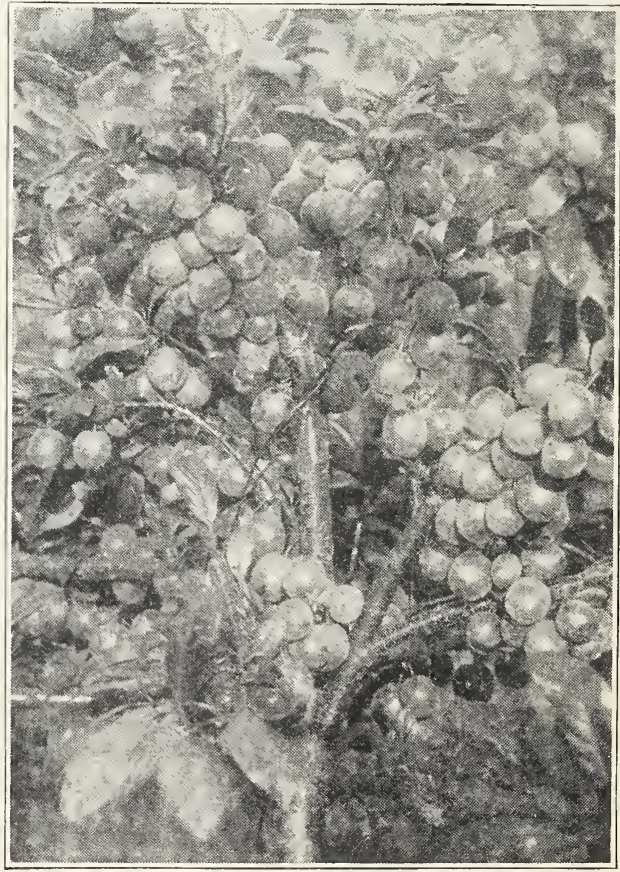

Splendid Plum

Of all the many fine plums sent out by Professor Hansen, of the South Dakota Experimental Farm, we consider Sapa the best. In fact we consider it the best of all the Sand Cherry Hybrids from any source. We always have Sapa sauce in our cellar, wouldn't be without it. 


\section{Our Model One Acre Plum Orchard}

We would suggest the following 140 trees as a model acre of plums: 35 Elliott, late; 30 Red Wing, midseason; 5 Sapa, just tor home use; 35 Tonka, midseason; 35 Underwood, early. This makes 140 trees which we will furnish F.O.B. Faribault, for $\$ 50.00$, in all No. 1 size, $11-16^{\prime \prime}, 5$ to 6 foot trees.

Tonka. This variety from the very beginning, twelve or fifteen years ago, when we first started to test out these new plums, we have always held as one of the very best plums of all. It starts to bear very young generally as a two-year-old and brings great crops continously every year of large oval shaped fruits that are an all over light red covered with a blue bloom. Tonka ripens and can be picked a week before it begins to mellow, which makes it a great shipping plum. Fine deep yellow flesh, sweet, small pit and free stone.

Underwood (Minnesota No. 91). This is the earliest of the large new plums. Ripens from about August 1st to 15 th and attains a size of one and three-fourths inches. The tree is one of the strongest growers of all these new plums and gets to be very large, furnishing a large bearing surface to produce wonderful crops of beautiful fruit. Limbs well and heavily shouldered enable it to carry its great loads without injury to the tree. This is the hardiest of all these new plums and in favored locations we do not hestitate to advise its planting far north. Fruit is very attractive red, firm juicy flesh, very small pit, free stone. Splendid quality. Hangs well to the tree and ripens over a period of two weeks. An annual bearer, having borne eight successive heavy crops.

\section{Price for all the above plums}

Strong 5 to 6 feet, 60 cents each; 5 for $\$ 2.50 ; 10$ for $\$ 4.50 ; 100$ for $\$ 40.00$. Strong 4 to 5 feet, 50 cents each; 5 for $\$ 2.00 ; 10$ for $\$ 3.75 ; 100$ for $\$ 35.00$.

\section{A New Plum The Splendid Plum}

Nothing is of greater interest to lovers of good fruit than the finding of some new fruit that shows real merit and so it was a real thrill that I experienced some six years ago when I happened to be walking through the orchard of a friend of mine and this friend pointed out to me a new plum which he had discovered. The orchard was a truly experimental one. It covered about two acres of ground and I think I am safe in saying it contained fully a hundred different varieties of plums and as many of apples. Mostly chance seedlings that this friend had picked up in his travels while selling nursery stock over the prairies and through the woods of the states of Wisconsin, lowa, Nebraska, South Dakota and Minnesota.

The most of the best of our standard varieties of fruit are chance seedlings found growing in some fence corner or other out of the way place. The Concord Grape, the Rhode Island Greening, Baldwin and Delicious Apples are all such and many others of our best fruits just grew and by chance were discovered.

This new plum came as one of a thousand or more little plum seedling trees purchased to be planted out in this friend's nursery to be used for budding plum onto. These little trees all grew but it was noticed at budding time that one of these little trees had made a wonderful growth and that in bark and leaf it was seemingly different from the rest. Instead of budding onto it, it was allowed to develop its own top and grow right there in the nursery row and come into bearing there. When it bore it was instantly realized that a wonderfully choice new plum was discovered, and top grafts were worked onto older seedling plum trees in the experimental orchard, and it was here that I ran across quite a few of the trees, mostly two year trees, loaded with great crops of very large, plums of uniform shape and of a beautiful clear, red color covered with minute white dots. Upon tasting the fruit I was truly delighted and pronounced it then and there the finest plum I had ever eaten.

That was six years ago. I have been in touch with the plum ever since and have never changed my opinion of it. The trees in my friend's orchard bear annually and regularly, large crops of uniformly beautiful large plums. We purchased six of the trees that fall and planted them in our plum orchard. They started bearing the second year and have borne regularly since. We have these plums growing right in our own experimental orchard side by side with all the great plums sent out by the Minnesota State Breeding Farm and we must pronounce this the finest and best of all. We are sure it is the best for our working men who, by the way, are pretty good plum testers, always make for these trees first and stay right by them until the last plum is gone.

The plum has not received a permanent name yet so we are sending it out under the temporary name of Splendid for it is truly a Splendid plum-just as the Delicious is a Delicious apple.

Splendid. A new plum, a chance seedling originated in southern Minnesota. Tree a rapid and shapely grower with strong branches growing outward and gracefully upward making a fine top. Fruit almost round, slightly larger at the base. Color a bright red, with numerous white dots, changing to deep red as it becomes thoroughly ripe. Flesh is firm and richly colored and the flavor is Splendid. Skin thin, pit small, fruit large, averaging about $1 \frac{1}{2}$ inch. A wonderful plum to can or eat from the hand. Price, 4 to 6 foot trees, $\$ 1.25$ each; 6 for $\$ 6.00 ; 12$ for $\$ 10.00$.

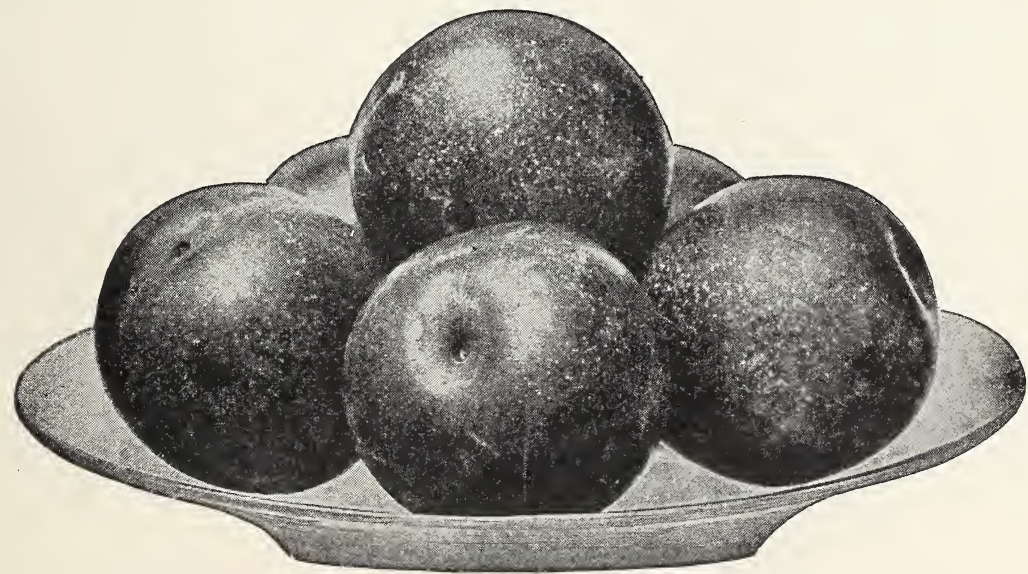




\section{A Splendid Plum Tree Free}

When we came to dig and grade our Splendid Plum Trees we found that we had some 200 nice trees that would not grade into our 4 to 6 foot grade. We have saved all these nice trees and intend to give one of them free as long as they last, with every cash order for plums for not less than one dozen trees where the order is mailed to us not later than March 31 , 1930, we will include free one nice tree of the New Plum Splendid.

\section{Pears}

Pears have been grown successfully in certain localities of southern Minnesota for many years. In Blue Earth County around Lake Crystal, a good many trees are to be found over eight inches in diameter. Many of these trees have borne several bushels of pears a year.

Pears, if planted in Minnesota, should be in sheltered locations and if this is done, now that we have discovered hardy pears, this delicious fruit can be grown in all the favored fruit localities of the State.

\section{Two New Pears}

Minnesota No. 1. This is the fine new pear from the Fruit Breeding Farm. A splendid large sweet pear that does well as far north as Minneapolis. Fruit large and much like the Flemish Beauty only hardier. Abundant bearer.

Mendel. This pear was produced at New Ulm, Minnesota, by Mr. Albert Pfender. The old tree is now some twenty-five years old and seemingly as hardy as ever. It stands right out on the prairie in an unfavorable location, and even under such conditions it produces great crops of splendid fruit. The fruit is large, and very fine flavored. Price of both Minnesota No. 1 and Mendel: Nice 4 to 6 foot trees, 75 cents each; 6 for $\$ 4.20$; 10 for $\$ 6.50$.

\section{Grapes}

We have selected a very attractive list of the very best of the hardy all around good grapes. That is, a list of grapes that will do best in the average location, with the average care as usually given grapes, and over the widest range of country.

Beta. Essentially the grape for the middle northwest. This grape will stand more cold than any other grape and needs no winter protection even in Minnesota. A very heavy bearer of medium sized grapes on a medium to large compact bunch. This grape is a cross between the Minnesota wild grape and the Concord. Has the wonderful jelly making qualities of the wild grape. Splendid to grow to cover arbors.

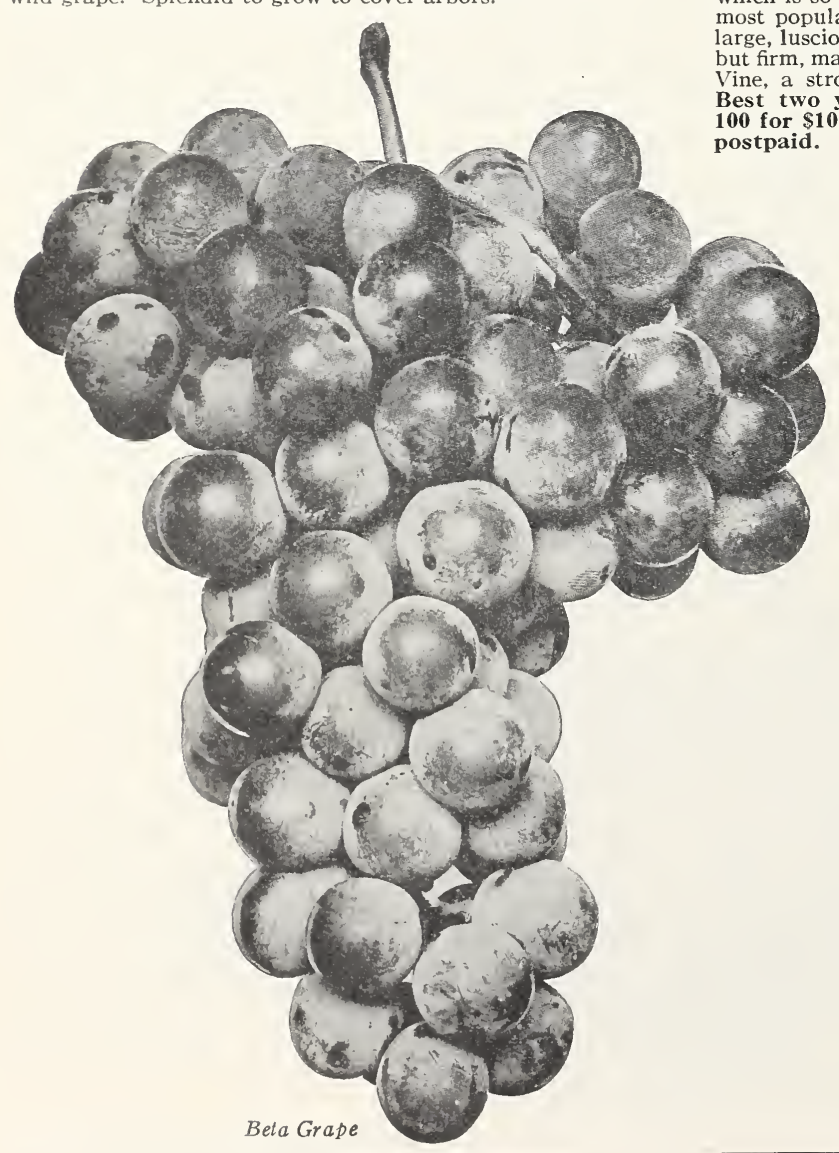

Briohton. Red. Bunches and berries large, dark red color, fine flavor, juicy and sugary. Almost seedless pulp. Quality very fine. Extremely hardy, bears abundantly and stands the heat of summer well. Ripens extra early. Concord. Black. The well known fine old market sort,
which is so largely planted in all sections, being decidedly the which is so largely planted in all sections, being decidedly the
most popular grape in America. Large, handsome bunches of large, luscious berries, covered with a rich bloom. Skin tender but firm, making it a good shipper; flesh juicy, sweet and tender. Vine, a strong, healthy grower, very hardy and productive. Best two year old plants, 15 cents each; 12 for $\$ 1.25$. 100 for $\$ 10.00$, not postpaid. 20 cents each; 12 for $\$ 1.50$, postpaid. blue bloom. This variety we recommend especially to our Northwestern orchardists and farmers. It is considered the best market variety in the grape growing districts of Minnesota, always yielding well and fruit selling at top prices. The bunches are of medium size, rarely shouldered. Berries large, round, of excellent quality. Desirable for market on account of its earliness.

Worden. Black. Bunch large, sometimes shouldered, compact berries very large, skin thin. Superior to the Concord in the following points: It is better in quality, has a larger berry, a more compact and handsome cluster and ripens five to ten days earlier. It fully equals Concord in vigor, health and productiveness.

Moore's Diamond. White. A seedling of the Concord, partaking of all ling of the Concord, partaking of all its good qualities. Of a beautiful
greenish-white color, without any of the yellow spots so common with white grapes. Berries are large, sweet, and of as good a quality as some of the more delicate varieties. It is hardy as the delicate varieties. It is hardy as the one of the best sorts. Ripens early, a few days before the Concord. Very hardy. Price, all grapes but Concord, 20 cents each; 12 for $\$ 2.00$, not prepaid; or 25 cents each; 12 for $\$ 2.25$, Postpaid, for strong two year, No. 1 vines. 


\section{Cherries}

Sour cherries are among the most profitable and necessary of all our fruits. The Early Richmond and Large Montmorency we do not recommend for planting in Minnesota, but carry them for our more southern and eastern customers. Nicollet and Compass on the other hand are iron clad in hardiness and are among the safest fruits for our people here to plant.

Early Richmond. A medium sized, bright red cherry with acid flavor. Hardy, early to ripen, very productive. The most popular of the early sour cherries. A fine thrifty tree. Best cherry for cooking.

Large Montmorency. A larger and better flavored cherry than Early Richmond but about ten days later. A dark cherry that bears enormous crops every year. Trees begin to bear second or third year after planting. The most popular cherry grown.

Nicollet. A cherry of great promise in the Middle Northwest on account of its fine quality, productiveness and extreme hardiness. Bears a cherry about the size and quality of the Early Richmond. Best sour cherry for Minnesota.

Compass. A cross between the western Sand Cherry and the native Minnesota plum. Bears a fruit that looks like a small, red plum. Not especially good to eat raw but when canned or preserved the cherry flavor is brought out and it is very desirable. Extremely desirable in very trying locations as it is very productive and absolutely hardy.

Price, Early Richmond and Large Montmorency, 2 year, 9-16 ft. trees, 4 to 6 feet, 75 cents each; 5 for $\$ 3.50 ; 10$ for $\$ 6.00$. Price, Nicollet and Compass, 2 year, 5 to $6 \mathrm{ft}$. trees, 65 cents each; 5 for $\$ 3.00 ; 10$ for $\$ 5.50$.

\section{An Evergreen Windbreak for the Farmer}

Have you ever stood on the south side of a house on a cold day of winter when the wind was in the northwest and the sun was shining? Of course you have and you have noticed how warm it seemed there; and then when you stepped away from the protection of the house and the wind struck you, al! of a sudden, how cold it seemed.

Well, this is just what happens to your house itself and to all your outbuildings, barns, hog houses, chicken coop, etc., and all that is inside of them and outside about them when a good, well grown evergreen windbreak surrounds your buildings on the north, west and south. It protects you and yours from the bitter wind and makes you that much warmer.

We spend thousands of dollars to put up houses to live in ourselves and for our live stock to be housed in and we know that much of this money is to secure extra comfort for ourselves and our animals from the cold and yet we overlook nature's greatest protection to us from that cold which, six months out of the year, we are continually fighting.

\section{How Large a Windbreak to Plant}

Plant a double row windbreak of evergreens to the north, west and south of all your buildings. A three row break is still better. And in ten years from the time you have planted the trees your buildings will be so protected from the wind in the winter that you wouldn't know it as the same place.

To plant a windbreak we must go about it right. In the first place determine where the rows are to run. The north break should extend entirely across the north of the farm home and all the farm buildings and yards to protect the live stock while in the yards in the winter. The west rows should meet the north row and extend far enougn south so as to break the wind entirely from the west and join the south row which should parallel the north row in its full length. The south row is very important because much of our bitterest winds of winter are from the south.

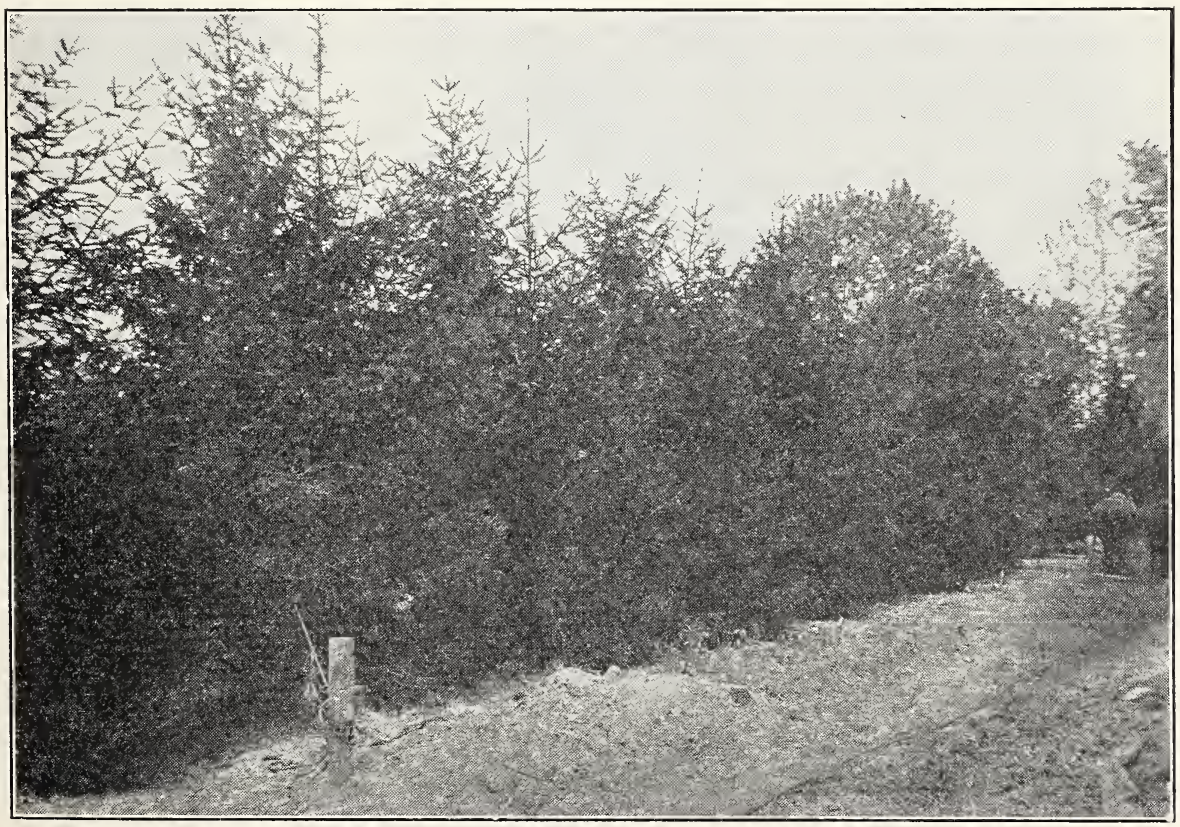

A Norway Spruce Windbreak Six Years After Planting 


\section{How to Plant and Care for it}

Get the soil into fine shape, well plowed and pulverized by double discing if possible, and then harrowed down smooth. Lay out your rows eighteen feet apart and plant the trees eighteen feet apart in the row, breaking joints, that is, have the tree of one come half way between the two trees nearest it in the next row.

Planting: Get the ground ready the first day you can so you can plant as soon as trees arrive. When the trees come do not open the package until ready to plant if you are going to plant within a day or two. Dig all the holes in a row before taking the trees from the package. Have a tub or large barn pail into which is mixed water and dirt which you stir into a very thin mud. Take a bundle of the trees from the package and shake off thoroughly all the straw, moss, or other packing material from the roots being careful to leave any dirt that may be on them. Do this cleaning just as quickly as you can as a minute's exposure to the sun and wind will often kill an evergreen. Then plunge these roots into your pail of mud and slush them up and down in the mud until they are thoroughly covered with it. Take a tree at a time from the mud and plant it carefully in the hole. The little tree should be planted so that the top of its roots are two inches below the level of the ground. Spread the roots out carefully, fill the hole half full of damp mellow soil, work the soil carefully in among the roots with the fingers and then get right into the hole with the feet and tramp the soil over the roots as hard as you can. Pour in a full pail of water to each tree and let this settle entirely away. Then fill in the hole and tamp lightly and finally scatter a little loose dirt over the surface so it won't bake.

When all the trees are planted, immediately run over the rows with a small tooth one or two horse cultivator and cultivate the rows twice a week until the middle of July just as you do corn. In the meantime plant corn in between the rows and about four rows of corn on each side of the rows. Don't let the boy cultivate your windbreak, do it yourself.

Husk this corn from the field leaving the stalks standing to hold the snow in the winter. Care for the break in this way for four years and you will have a wonderful grove coming on.

\section{Our Norway Spruce}

We have a splendid lot of Norway Spruce, Evergreens coming on for this spring, solely for windbreak stock. We think the Norway Spruce the best evergreen for this purpose.

We will guarantee these evergreens to be absolutely alive when they reach you. We will do our part right.

We have these evergreen in two grades. Those that have been twice root pruned and twice transplanted, and a year younger grade once root pruned and once transplanted. Fine Norway Spruce, Twice Transplanted, Nice 12 to 18 inch grade, 25 for $\$ 6.00 ; 50$ for $\$ 11.00 ; 100$ for $\$ 20.00 ; 1000$ for $\$ 175.00$. Fine Norway Spruce, Once Transplanted, Nice 10 to 12 inch grade, 25 for $\$ 3.50 ; 50$ for $\$ 6.00 ; 100$ for $\$ 10.00 ; 1000$ for $\$ 95.00$. By Express or Freight.

\section{Pigeons and Bantams}

White Swiss Montaines. One of the most beautiful and at the same time one of the greatest of the squab pigeons. A pure white pigeon with a very long stylishly carried body. We have some of the best stock in America. Buy a few pairs and grow your own squabs. Mated pairs always on hand for sale. Pair for $\$ 3.00 ; 10$ pair for $\$ 25.00$.

Golden Seabright Bantams. The most beautiful of all the bantam family. We have grown Seabright Bantams ever since I was a boy. They are not only the most beautiful but they are the best layers of the bantams and lay an egg that would surprise you for its size, and lots of them. Buy a pair for the children. Per pair $\$ 5.00$.

\section{Red Raspberries}

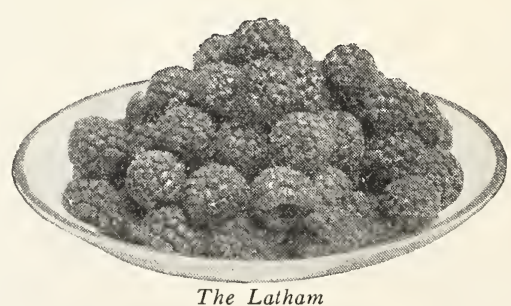

"In these days when the one crop farmer is finding it so hard to $\mathrm{m}$ ake both ends meet and our economists and our would-be economists are casting about in all directions for some means to help the farmer out, we have often wondered why small fruits and especially red raspberries have not been thought of. Dairying and the diversified farming that necessarily goes with it is the cureall advocated in the great farming districts of our country. But dairying, like all other branches of farming, if carried too far will be overdone.

We wrote the above into our catalog seven years ago and now our prophecy has come true. With a surplus of 30,000 . 000 pounds of butter on hand we should stop and think. On the other hand but few people think of the growing of small fruits in a commercial way. Now every town of a thousand inhabitants will furnish a market for one good small fruit grower.

Two acres of good land planted to our Mosaic Free Latham Red Raspberry will put at least one family in every farming community right onto its feet.

If the Minnesota State Breeding Farm had originated no other fruit of promise, the production of this one superb red raspberry would have repaid the state for all the funds expended at the station. When we first took this berry up, we were not greatly impressed with it as the canes on our soil were not as rank growers as many of our other varieties. But when our original planting became two years old and the plants came into full bearing we recognized that we had in the Minnesota No. 4, as it was then called, the most remarkable red raspberry ever sent out to date. The berry is of immense size and the bushes are just loaded to the ground with their great crop of fruit. The plant is not as great a multiplier as some varieties of reds which is a very desirable feature. Still, enough strong hardy plants are produced each year to keep the bed renewed and in good thrifty bearing condition Berries are dark red in color, very large, and firm. An easy variety to pick, shows up splendidly in the box, and because of its immense size readily demands the best price when sold. The raspberry growers about Lake Minnetonka, Minnesota's great fruit growing district, are discarding almost all other varieties for Latham which they claim produces two to one of any other variety. 


\section{ORDER SHEET \\ BRAND PEONY FARMS, Inc. \\ Peonies, Iris, Improved French Lilacs and Improved Philadelphus \\ Box 408 \\ FARIBAULT, MINNESOTA}

Read This: As a rule any shipment can go cheaper by Post than by Express. If you order either one or two roots, you should allow 25 cents for your shipment. If your order calls for a greater number of roots, we will send your order Post Paid if you will state in your order that you will send us the postage after you receive your package.
DO NOT WRITE IN THIS SPACE

Peony Order No.

Iris Order No.

Lilac or Philadelphus No.

Date Received

Amount Received

\section{Date}

Name Miss, Mrs.

\section{Street Address or}

\section{Rural Route}

\section{Post Office}

State

Shipping Address if not

the same as Post Office

Amount Enclosed \$

\section{Check or Draft Money Order Cash}

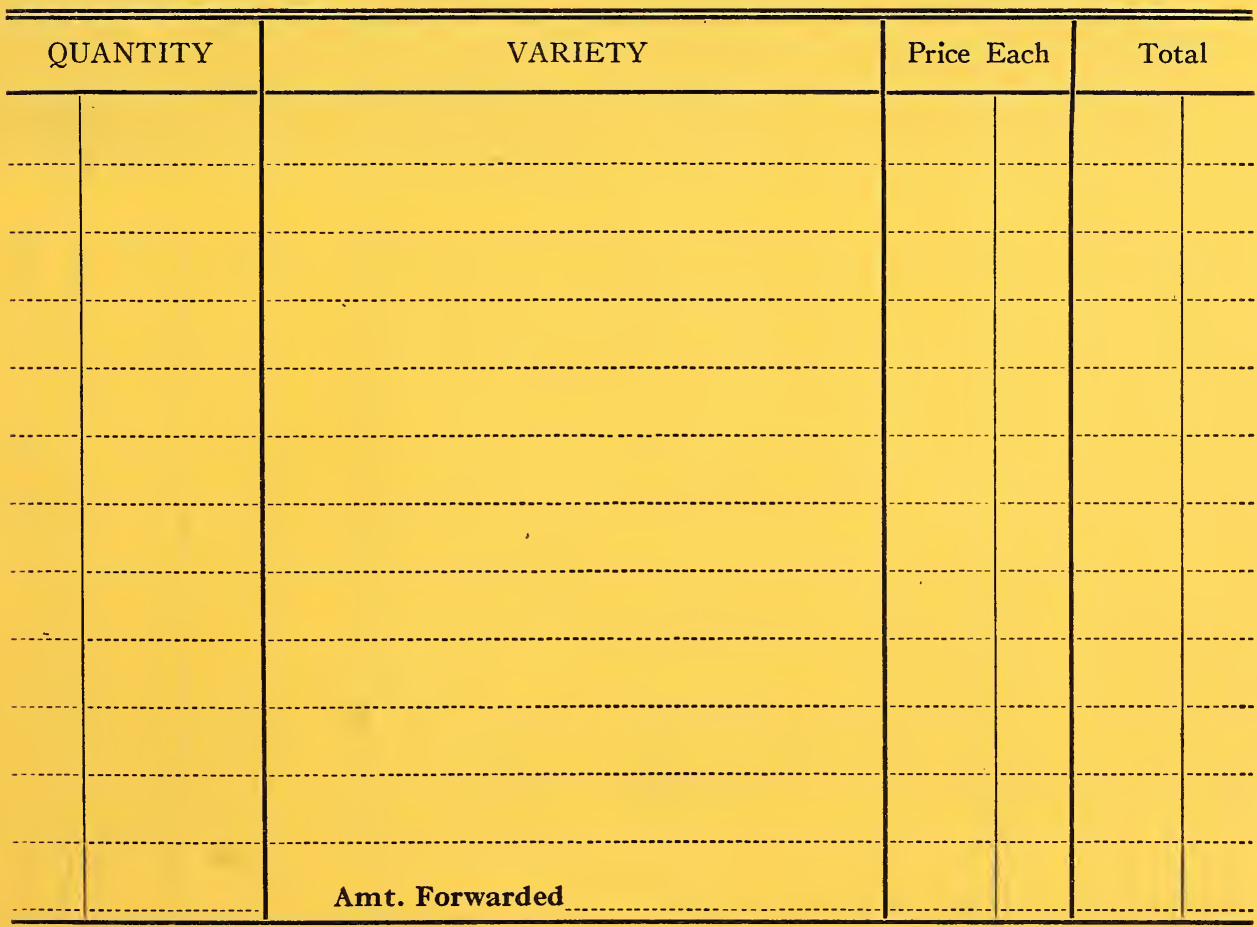




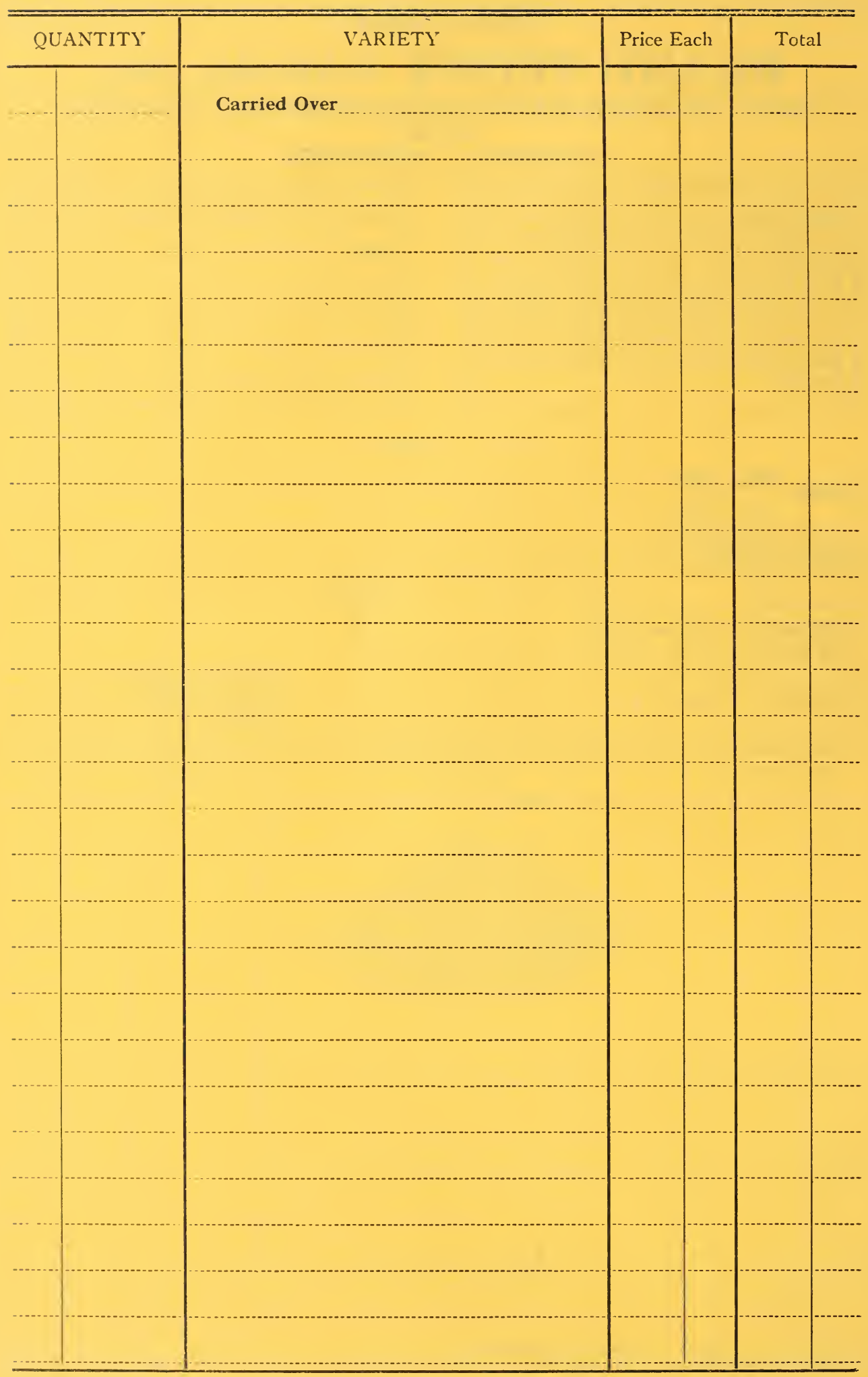




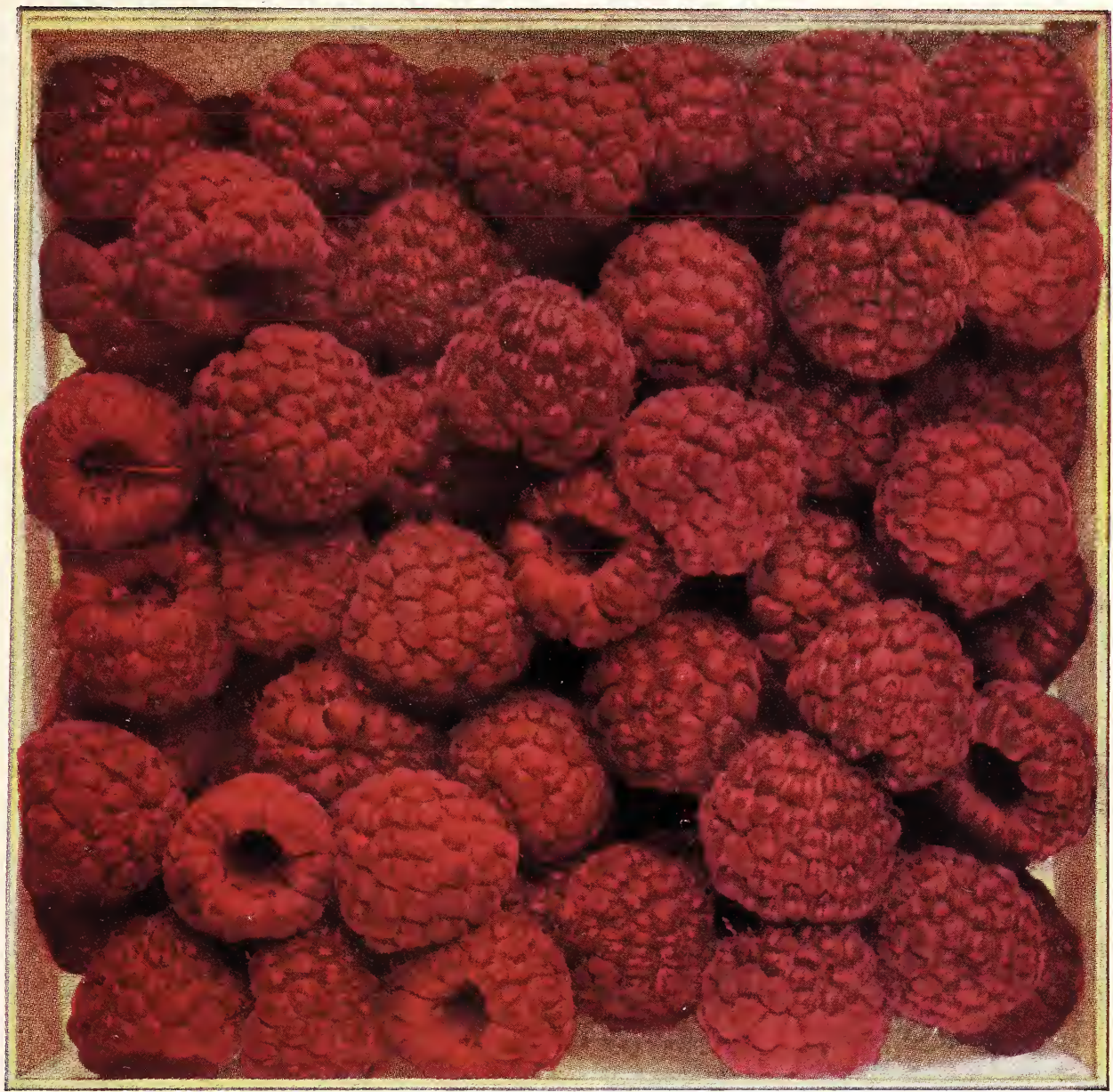

A Pint of Latham Raspberries.

\section{LATHAM Bears Big Crop First Year}

In the Spring of 1923 we had quite a quantity of Latham plants left in our storage after the selling season closed. These we plarted out into the field on the 6 th of June; mark the date. The tops of these plants were not cut back as they should have been after planting. They were well cultivated, threw out side branches and to the amazement of everyone, produced over 1200 pints of great, big, luscious berries that sold at $20 \mathrm{c}$ a pint. The plants covered about one-fourth of an acre. The gross return was $\$ 240.00$, or at the rate of $\$ 960.00$ per acre from plants the same year they were planted.

\section{Latham Nets $\$ 1000$ per Acre}

In the spring of 1928 we had a small part of a field of Latham that we did not sell, so we did not dig it. There were 11 rows in the field and each row 504 feet long. By actual measurement this field covered somewhat less than one-half acre. We picked from this field and sold berries which left us a net profit of $\$ 484.00$, which was at the rate of $\$ 1000.00$ net profit per acre that year.

\section{Latham for the Back Yard}

Every family that has as much as a single city lot should plant Latham Raspberries. There is no other fruit that will give as great returns. Eren as small amount as a dozen plants, well cared for, will provide a small family with several pints of luscious Raspberries a day during the fruiting season; and 25 plants will supply a large family, while 100 plants will not only give a family all they want for immediate use, but lots of fruit to put down for Winter.

\section{Our Latham are Mosaic Free}

The disease to which the red Raspberry is most subject is mosaic. Our fields are carefully checked over and inspected three times each Summer by our State Raspberry Inspector, and our plants are certified each shipment.

\section{Grades and Prices}

We grade all our Latham which we offer for sale into two grades. Our LARGE GRADE and our MEDIUM GRADE.

\section{PRICES}

LARGE GRADE: 12 for $\$ 1.60 ; 25$ for $\$ 2.00 \cdot 50$ for $\$ 3.50 ; 100$ for $\$ 4.50$, postpaid. 1000 for $\$ 35.00$, by express or freight, collect.

MEDIUM GRADE: 25 for $\$ 1.10 ; 50$ for $\$ 2.10 ; 100$ for $\$ 3.25$, postpaid. 1000 for $\$ 20.00$, by express or freight collect.

(250 at 1000 rate, either grade).

SPECIAL LATHAM OFFER. We will include in every order received for Latham Raspberry plants at the above prices by March 20th, one choice Lilac bush, named variety. 


\section{RED - LEAVED BARBERRY ( Berberis Thunbergi $)$}

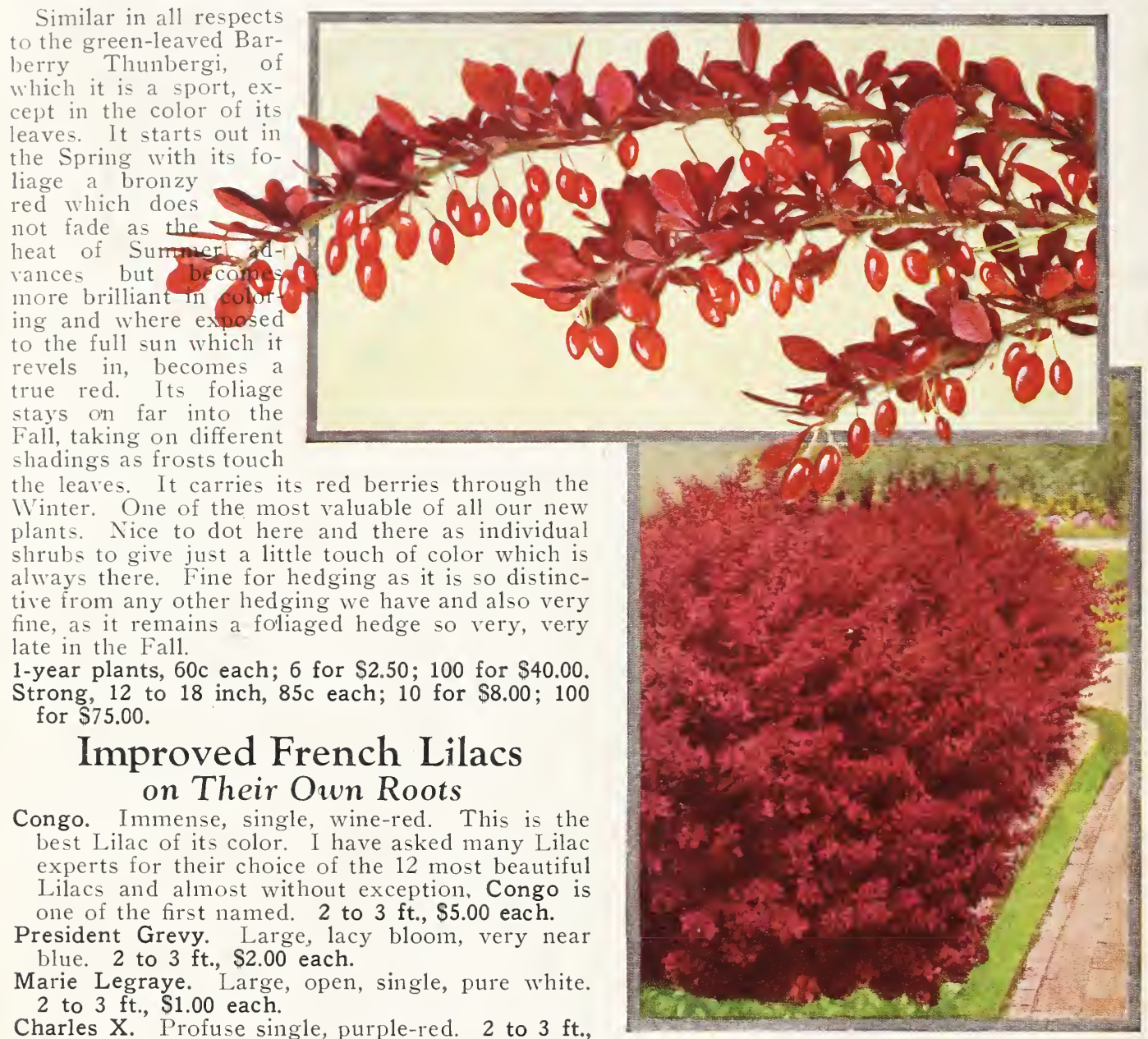

Charles X. Profuse single, purple-red. 2 to $3 \mathrm{ft}$., $\$ 1.00$ each.

One each of the four varieties, 2 to $3 \mathrm{ft}$., $\$ 7.00$.

Red-Leaved Barberry.

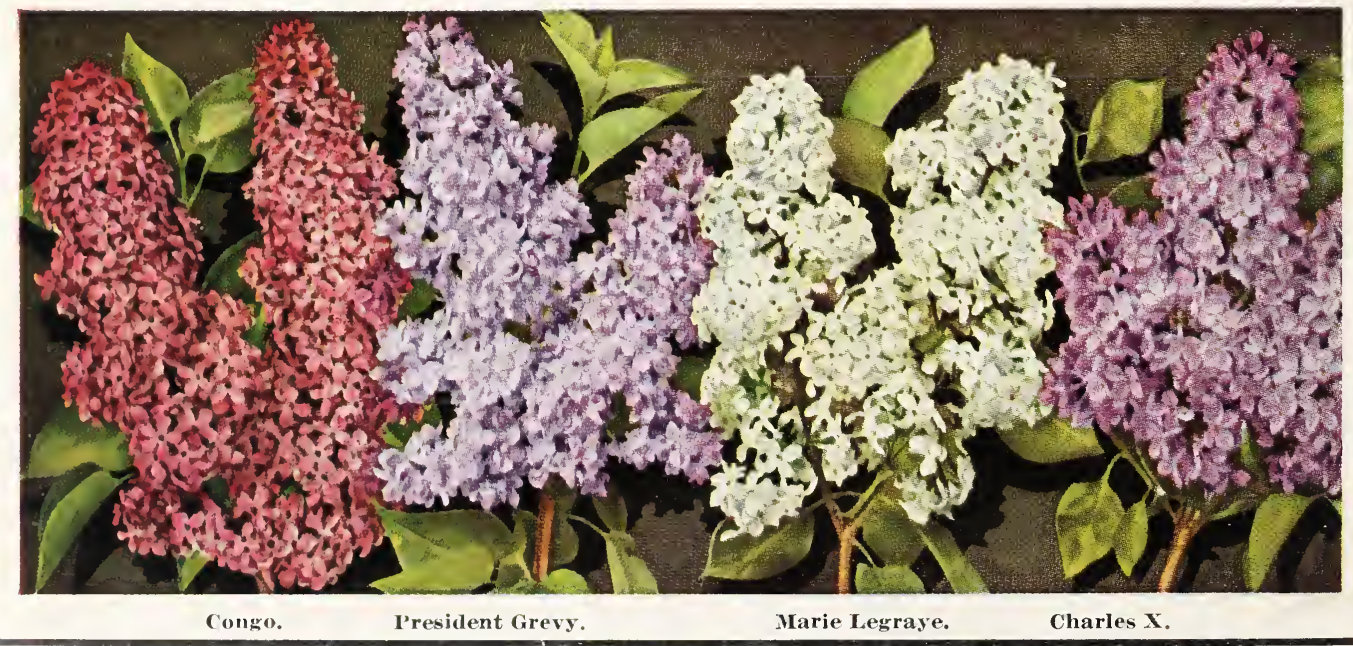

